Cover: Photograph showing Clark's grebe sitting on a nest at Thermalito Afterbay, California. Photograph taken by Alex Hartman in 2012. 


\section{Estimating Exposure of Piscivorous Birds and Sport Fish to Mercury in California Lakes Using Prey Fish Monitoring-A Predictive Tool for Managers}

By Joshua T. Ackerman, C. Alex Hartman, Collin A. Eagles-Smith, Mark P. Herzog, Jay Davis, Gary Ichikawa, and Autumn Bonnema

Prepared for the California State Water Resources Control Board, Surface Water Ambient Monitoring Program

Open-File Report 2015-1106

U.S. Department of the Interior

U.S. Geological Survey 


\section{U.S. Department of the Interior \\ SALLY JEWELL, Secretary}

\section{U.S. Geological Survey \\ Suzette M. Kimball, Acting Director}

U.S. Geological Survey, Reston, Virginia: 2015

For more information on the USGS—-the Federal source for science about the Earth, its natural and living resources, natural hazards, and the environment-visit http://www.usgs.gov or call 1-888-ASK-USGS

For an overview of USGS information products, including maps, imagery, and publications, visit http://www.usgs.gov/pubprod

To order this and other USGS information products, visit http://store.usgs.gov

Any use of trade, firm, or product names is for descriptive purposes only and does not imply endorsement by the U.S. Government.

Although this information product, for the most part, is in the public domain, it also may contain copyrighted materials as noted in the text. Permission to reproduce copyrighted items must be secured from the copyright owner.

Citation:

Ackerman, J.T., Hartman, C.A., Eagles-Smith, C.A., Herzog, M.P., Davis, J., Ichikawa, G., and Bonnema, A., 2015, Estimating exposure of piscivorous birds and sport fish to mercury in California lakes using prey fish monitoring-A predictive tool for managers: U.S. Geological Survey Open-File Report 2015-1106, 48 p., http://dx.doi.org/10.3133/ofr20151106.

ISSN 2331-1258 (online) 


\section{Acknowledgments}

This research was funded by the California State Water Resources Control Board, Surface Water Ambient Monitoring Program, Bioaccumulation Oversight Group, U.S. Geological Survey Ecosystems Mission Area, and U.S. Geological Survey Contaminants Biology Program. We thank the members of the Bioaccumulation Oversight Group for project support and guidance; Ryan Martin of the California Department of Water Resources, Dave Mauser of the Tule Lake National Wildlife Refuge, and the Plumas Audubon Society for logistical support; Seth Wile, Ian Isler, Trevor Watts, Ashley Casey, Michelle Boyles, Garth Herring, John Pierce, Joe Schultz, Tully Rohrer, and Brandon Kowalski for field and laboratory assistance; Jim Wiener, Harry Ohlendorf, Chris Schmitt, Amanda Palumbo, Janis Cooke, Rob Brodberg, Stephen Louie, and the other members of the Bioaccumulation Oversight Group for providing helpful comments on earlier versions of the report; and Julie Yee for statistical advice. 
This page left intentionally blank 


\section{Contents}

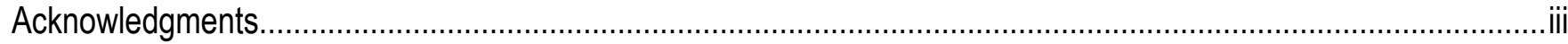

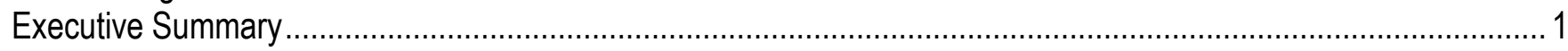

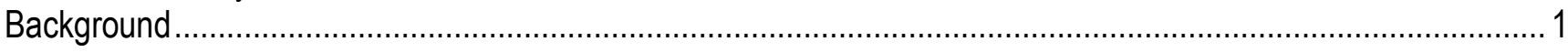

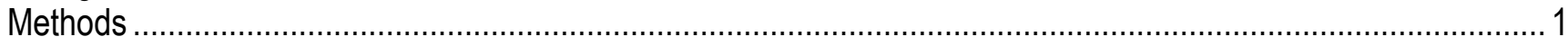

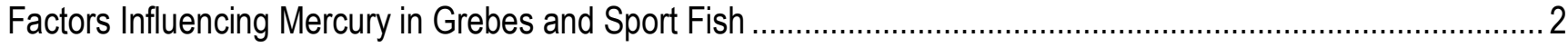

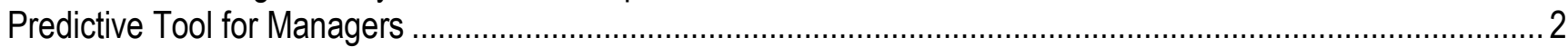

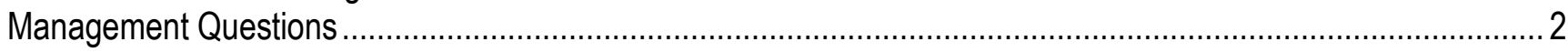

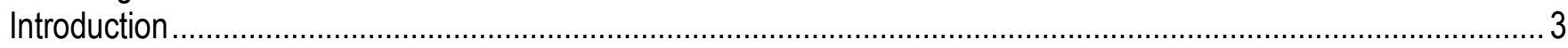

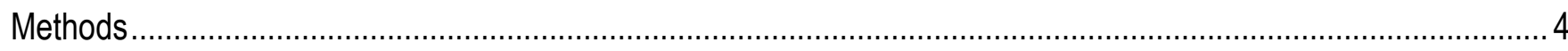

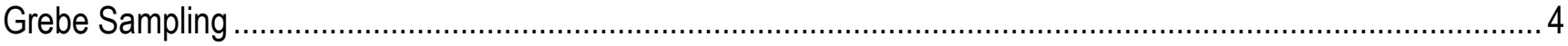

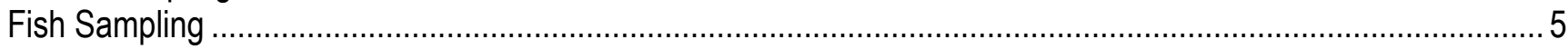

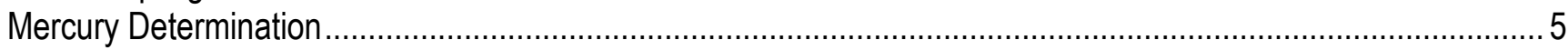

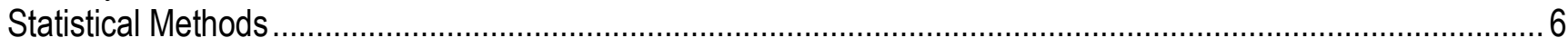

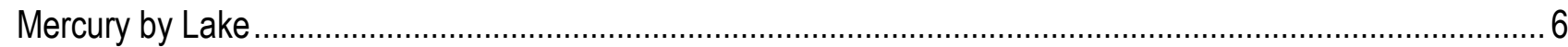

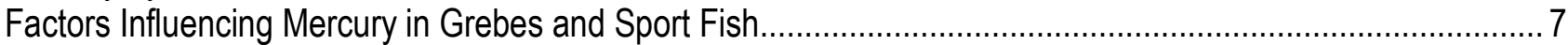

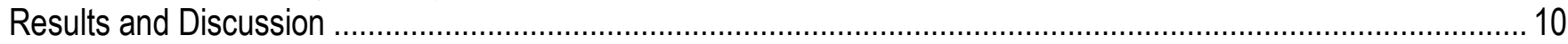

Mercury Concentrations among Lakes............................................................................................. 10

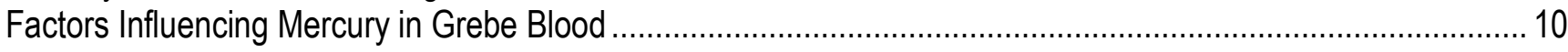

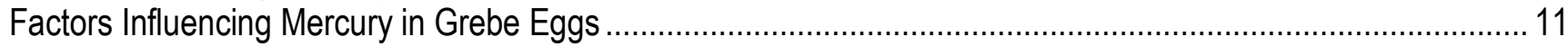

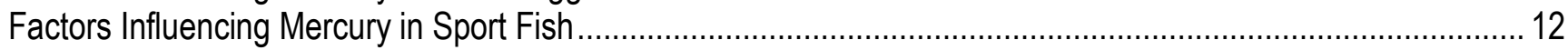

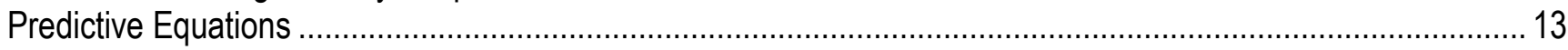

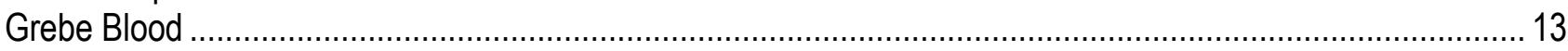

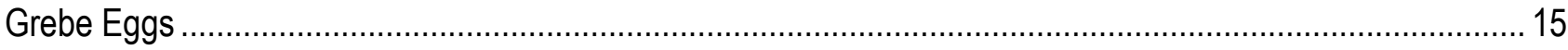

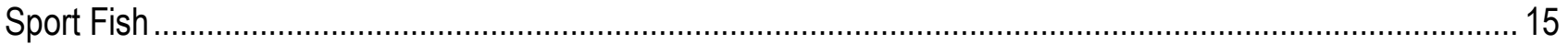

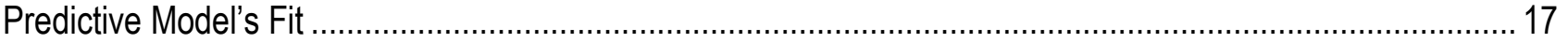

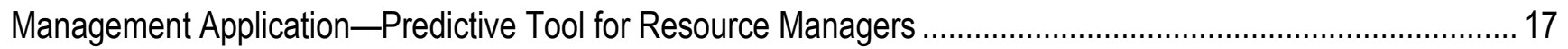

Mercury Correlations between Grebe Blood, Grebe Eggs, and Sport Fish .................................................... 19

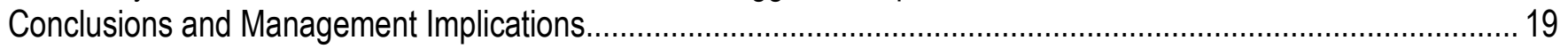

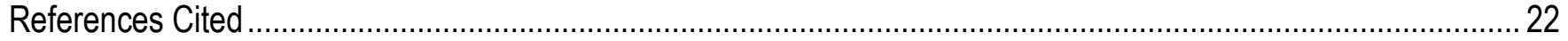




\section{Figures}

Figure 1. Map showing location of the 25 lakes and reservoirs where grebes, sport fish, and prey fish were collected for mercury analyses of blood, eggs, and tissue, California, 2012-13....

Figure 2. Graph showing total mercury $(\mathrm{THg})$ concentrations (in micrograms per gram wet weight $[\mu \mathrm{g} / \mathrm{g} \mathrm{ww}]$ ) in blood of male and female Clark's grebes and western grebes captured at 25 lakes in California, 2012-13.......

Figure 3. Graphs showing total mercury (THg) concentrations (in micrograms per gram dry weight [ $\mu \mathrm{g} / \mathrm{g} \mathrm{dw}$ ] [left $Y$ axis]; or in $\mu \mathrm{g} / \mathrm{g}$ wet weight [ww] [right $Y$ axis]) in grebe blood (top left panel), prey fish (top right panel), grebe eggs (bottom left panel), and sport fish (bottom right panel) sampled at as many as 25 lakes in California, 2012-13

Figure 4. Graphs showing total mercury $(\mathrm{THg})$ concentrations (in micrograms per gram dry weight [ $\mu \mathrm{g} / \mathrm{g} \mathrm{dw}$ ] [left $Y$ axis] or in $\mu \mathrm{g} / \mathrm{g}$ wet weight [ww] [right $Y$ axis]) in (A) whole prey fish by species from 25 lakes and (B) sport fish fillets by species from 24 lakes in California, 2012-13.....

Figure 5. Graphs showing total mercury ( $\mathrm{THg}$ ) concentrations (in micrograms per gram dry weight [ $\mu \mathrm{g} / \mathrm{g} \mathrm{dw}$ ] [left $Y$ axis] or $\mu \mathrm{g} / \mathrm{g}$ wet weight [ww] [right $Y$ axis]) in grebe blood (top panel),grebe eggs (middle panel), and sport fish (bottom panel) versus THg concentrations in prey fish ( $\mu \mathrm{g} / \mathrm{g} \mathrm{dw}$ [top row X axis] or $\mu \mathrm{g} / \mathrm{g}$ ww [bottom row $X$ axis]) sampled at up to 25 lakes in California, 2012-13......

Figure 6. Graphs showing total mercury (THg) concentrations (in micrograms per gram wet weight $[\mu \mathrm{g} / \mathrm{g} \mathrm{ww}]$ ) in grebe blood by species and sex versus THg concentrations in prey fish ( $\mu \mathrm{g} / \mathrm{g}$ dry weight [dw] [top row $X$ axis] or in $\mu \mathrm{g} / \mathrm{g}$ ww [bottom row $X$ axis]) sampled at 25 lakes in California, 2012-13.

Figure 7. Graphs showing total mercury (THg) concentrations (in micrograms per gram fresh water weight $[\mu \mathrm{g} / \mathrm{g} \mathrm{fww}]$ ) in grebe eggs by species and egg type (random or abandoned) versus THg concentrations in prey fish (in $\mu \mathrm{g} / \mathrm{g}$ dry weight [dw] [top row $X$ axis] or in $\mu \mathrm{g} / \mathrm{g}$ wet weight [ww] [bottom row $X$ axis]) sampled at seven lakes in California, 2012-13.

Figure 8. Graphs showing total mercury $(\mathrm{THg})$ concentrations (in micrograms per gram dry weight [ $\mu \mathrm{g} / \mathrm{g} \mathrm{dw}$ ] [left axis] or $\mu \mathrm{g} / \mathrm{g}$ wet weight [ww] [right $Y$ axis]) in sport fish by species versus THg concentrations in prey fish ( $\mu \mathrm{g} / \mathrm{g} \mathrm{dw}$ [top row $X$ axis] or $\mu \mathrm{g} / \mathrm{g}$ ww [bottom row $X$ axis]) sampled at 24 lakes in California, 2012-13.

Figure 9. Graphs showing total mercury (THg) concentrations (in micrograms per gram dry weight [ $\mu \mathrm{g} / \mathrm{g} \mathrm{dw}$ ] [left $Y$ axis] or $\mu \mathrm{g} / \mathrm{g}$ wet weight [ww] [right $Y$ axis]) in grebe blood (top panel), grebe eggs (middle panel), and sport fish (bottom panel) versus THg concentrations in prey fish ( $\mu \mathrm{g} / \mathrm{g} \mathrm{dw}$ [top row $X$ axis] or $\mu \mathrm{g} / \mathrm{g}$ ww [bottom row $X$ axis]) sampled at as many as 25 lakes in California, 2012-13

Figure 10. Graphs showing model-predicted mean \pm standard errors total mercury (THg) concentrations (in micrograms per gram dry weight [ $\mu \mathrm{g} / \mathrm{g} \mathrm{dw}$ ] [left $Y$ axis] or $\mu \mathrm{g} / \mathrm{g}$ wet weight [ww] [right $Y$ axis]) versus observed (raw) THg concentrations ( $\mu \mathrm{g} / \mathrm{g}$ dw [top row $X$ axis] or $\mu \mathrm{g} / \mathrm{g} w \mathrm{w}$ [bottom row $X$ axis]) in grebe blood (top panel; $n=354$ ), sport fish (middle panel, $n=230$ ), and grebe eggs (bottom panel; $n=101$ ) in California, 2012-13 ............. 33

Figure 11. Example of our predictive tool for use by natural resource managers using Lake Berryessa specific data..... 34

Figure 12. Example of our predictive tool for use by natural resource managers using Big Lake specific data ...... 35 Figure 13. Graphs showing total mercury (THg) concentrations in grebe blood versus THg concentrations (in micrograms per gram dry weight [ $\mu \mathrm{g} / \mathrm{g} \mathrm{dw}$ ] [top row $\mathrm{X}$ axis] or $\mu \mathrm{g} / \mathrm{g}$ wet weight [ww] [bottom row X axis]) in sport fish (top panel), grebe eggs versus sport fish (middle panel), and grebe eggs versus grebe blood (bottom panel) at up to 25 lakes in California, 2012-13. 


\section{Tables}

Table 1. Sample size and relative risk of blood mercury to female and male western and Clark's grebes by lake in California, 2012-13

Table 2. Sample size of randomly sampled and abandoned eggs for western and Clark's grebes by lake in California, 2012-13.

Table 3. Common names, scientific names, sample sizes, and proportion of prey fish species sampled in California, 2012-13.

Table 4. Species and number of prey fish sampled by lake in California, 2012-13

Table 5. Common names, scientific names, sample sizes, and proportion of sport fish species sampled in California, 2012-13

Table 6. Species and number of sport fish sampled by lake in California, 2012-13.

Table 7. Location, size, perimeter, elevation, and shape index for each of the 25 lakes sampled in California, 2012-13

Table 8. Ranking of candidate model set describing western grebe and Clark's grebe blood total mercury ( $\mathrm{THg}$ ) concentrations ( $n=353$ grebes) at 25 lakes, California, 2012-13

Table 9. Ranking of candidate model set describing western grebe and Clark's grebe egg total mercury $(\mathrm{THg})$ concentrations ( $n=101$ eggs) at seven lakes, California, 2012-13

Table 10. Ranking of candidate model set describing sport fish total mercury $(\mathrm{THg})$ concentrations ( $n=230$ fish) at 24 lakes in California, 2012-13

Table 11. Appropriate range of data for each variable used in the predictive tool for use by natural resource managers

Table 12. Toxicity benchmarks and associated citations used in the predictive tool for natural resource managers. 


\section{Conversion Factors}

\begin{tabular}{|c|c|c|}
\hline Multiply & By & To obtain \\
\hline \multicolumn{3}{|c|}{ Length } \\
\hline centimeter (cm) & 0.3937 & inch (in.) \\
\hline millimeter (mm) & 0.03937 & inch (in.) \\
\hline meter (m) & 3.281 & foot $(\mathrm{ft})$ \\
\hline kilometer (km) & 0.6214 & mile (mi) \\
\hline meter (m) & 1.094 & yard (yd) \\
\hline \multicolumn{3}{|c|}{ Area } \\
\hline hectare (ha) & 2.471 & acre \\
\hline hectare (ha) & 0.003861 & square mile $\left(\mathrm{mi}^{2}\right)$ \\
\hline \multicolumn{3}{|c|}{ Volume } \\
\hline liter (L) & 0.264172 & gallon (gal) \\
\hline milliliter $(\mathrm{mL})$ & 0.0333814 & ounce, fluid (fl. oz) \\
\hline \multicolumn{3}{|c|}{ Mass } \\
\hline gram (g) & 0.03527 & ounce, avoirdupois (oz) \\
\hline milligram (mg) & 0.00003527 & ounce, avoirdupois (oz) \\
\hline microgram $(\mu \mathrm{g})$ & 0.00000003527 & ounce, avoirdupois (oz) \\
\hline
\end{tabular}

Temperature in degrees Celsius $\left({ }^{\circ} \mathrm{C}\right)$ may be converted to degrees Fahrenheit $\left({ }^{\circ} \mathrm{F}\right)$ as follows:

$$
{ }^{\circ} \mathrm{F}=\left(1.8 x^{\circ} \mathrm{C}\right)+32 \text {. }
$$

\section{Abbreviations and Acronyms}

\begin{tabular}{ll}
\hline $\mathrm{dw}$ & dry weight \\
$\mathrm{ww}$ & wet weight \\
$\mathrm{fww}$ & fresh wet weight \\
$\mathrm{Hg}$ & mercury \\
$\mathrm{THg}$ & total mercury \\
$\mathrm{MeHg}$ & methylmercury \\
$\mu \mathrm{g} / \mathrm{g}$ & micrograms per gram \\
\hline
\end{tabular}




\section{Estimating Exposure to Piscivorous Birds and Sport Fish to Mercury in California Lakes Using Prey Fish Monitoring-A Predictive Tool for Managers}

By Joshua T. Ackerman¹, C. Alex Hartman¹, Collin A. Eagles-Smith¹, Mark P. Herzog1, Jay Davis², Gary Ichikawa ${ }^{3}$, and Autumn Bonnema ${ }^{3}$

\section{Executive Summary}

\section{Background}

- Numerous water bodies in California are listed under the Clean Water Act as being impaired by mercury $(\mathrm{Hg})$ contamination. The Surface Water Ambient Monitoring Program, via the Bioaccumulation Oversight Group, has recently completed statewide surveys of contaminants in sport fish tissue from California lakes, rivers, and coastal waters. This effort focused on human health issues, but did not include beneficial uses by wildlife.

- We developed a tool for estimating wildlife and sport fish risk due to $\mathrm{Hg}$ exposure based on $\mathrm{Hg}$ concentrations in prey fish. This tool can be used to predict $\mathrm{Hg}$ concentrations in grebe blood, grebe eggs, and sport fish, thus facilitating a feasible alternative for estimating wildlife exposure to $\mathrm{Hg}$ when more comprehensive wildlife sampling is not feasible.

\section{Methods}

- We used western grebes (Aechmophorus occidentalis) and Clark's grebes (Aechmophorus clarkii) as indicators of wildlife exposure to $\mathrm{Hg}$ in California lakes. Specifically, we sampled grebes, prey fish, and sport fish simultaneously at up to 25 lakes throughout California during the spring and summer of 2012 and 2013, seasons when breeding birds are particularly vulnerable to Hg-induced reproductive impairment.

- We sampled and analyzed total mercury (THg) concentrations in tissue from 354 grebes at 25 lakes, 101 grebe eggs at 7 lakes, 505 prey fish of 14 species at 25 lakes, and 230 sport fish of 5 species at 24 lakes.

- We used linear mixed-effect models, Akaike's Information Criterion, and model-averaging to evaluate which variables influenced $\mathrm{THg}$ concentrations in grebe blood, grebe eggs, and sport fish. For each of these tissues, we built a set of candidate models based on potential predictor variables describing the (1) specific tissue, (2) lake attributes, and (3) THg concentrations in prey fish.

\footnotetext{
${ }^{1}$ U.S. Geological Survey.

${ }^{2}$ San Francisco Estuary Institute.

${ }^{3}$ California Department of Fish and Wildlife.
} 


\section{Factors Influencing Mercury in Grebes and Sport Fish}

- Data strongly supported the influence of $\mathrm{THg}$ concentrations in prey fish on $\mathrm{THg}$ concentrations in grebe blood, grebe eggs, and sport fish.

- The most parsimonious model describing THg concentrations in grebe blood included THg concentrations in prey fish, grebe species, grebe sex, wing molt index, and lake perimeter. Specifically, predicted THg concentrations in grebe blood increased by 824 percent (from 0.26 to 2.37 micrograms per gram $[\mu \mathrm{g} / \mathrm{g}$ ] wet weight [ww]) over the observed range of $\mathrm{THg}$ concentrations in prey fish among lakes $(0.03 \pm 0.01$ to $0.70 \pm 0.18 \mu \mathrm{g} / \mathrm{g}$ dry weight [dw]).

- The most parsimonious model describing THg concentrations in grebe eggs included $\mathrm{THg}$ concentrations in prey fish, date, and lake perimeter, but date and lake perimeter contributed little to explaining $\mathrm{THg}$ concentrations in grebe eggs. Similar to THg concentrations in grebe blood, predicted THg concentrations in grebe eggs increased by 500 percent (from 0.04 to 0.24 $\mu \mathrm{g} / \mathrm{g}$ fresh wet weight [fww]) over the observed range of $\mathrm{THg}$ concentrations in prey fish among lakes $(0.03 \pm 0.01$ to $0.70 \pm 0.18 \mu \mathrm{g} / \mathrm{g} \mathrm{dw})$.

- The most parsimonious model describing THg concentrations in sport fish included THg concentrations in prey fish, sport fish species, sport fish length, lake elevation, lake area, and a sport fish species $\times$ total length interaction, but lake area had only a marginal effect. Specifically, predicted THg concentrations in sport fish increased by 1,023 percent (from 0.20 to $2.21 \mu \mathrm{g} / \mathrm{g} \mathrm{dw}$ ) over the observed range of $\mathrm{THg}$ concentrations in prey fish among lakes $(0.03 \pm 0.01$ to $0.70 \pm 0.18 \mu \mathrm{g} / \mathrm{g} \mathrm{dw})$.

\section{Predictive Tool for Managers}

- We built predictive equations for each tissue type using model-averaged coefficients from our full candidate model set (a total of 3,456 models for grebe blood, 384 models for grebe eggs, and 480 models for sport fish).

- We then built a predictive tool for use by natural resource managers using these predictive equations (see Microsoft ${ }^{\circledR}$ Excel file entitled "USGS Wildlife and Sport Fish Risk Estimator Tool Final.xlsx," available at http://www.werc.usgs.gov/mercuryriskinlakes).

- Tool users will enter THg concentrations in prey fish, date sampled, and the specific lake's attributes; our tool will then predict $\mathrm{THg}$ concentrations in grebe blood, grebe eggs, and sport fish.

- Furthermore, our tool uses these estimated values to assess the relative risk to the animal by comparing the estimated $\mathrm{THg}$ concentrations to published toxicity benchmarks.

\section{Management Questions}

We also addressed three specific management questions and discussed the tool's broader application for estimating risk to wildlife in California lakes and reservoirs:

1. Does methylmercury pose significant risks to aquatic life in a representative sample of California lakes and reservoirs?

2. Can a correlational approach be applied on a statewide basis to estimate risks to birds?

3. What are appropriate water-quality monitoring requirements to address methylmercury exposure in wildlife? 


\section{Introduction}

Numerous water bodies in California are listed under the Clean Water Act as being impaired due to mercury (Hg) contamination. The Surface Water Ambient Monitoring Program (SWAMP), via the Bioaccumulation Oversight Group (BOG), has recently completed statewide surveys of contaminants in sport fish tissue from more than 250 lakes and rivers in California and throughout coastal waters (Davis and others, 2010, 2012). This effort focused on human health issues but did not include beneficial uses by wildlife. Many piscivorous birds such as grebes, terns, cormorants, and mergansers eat fish smaller than those that were sampled by BOG, and sport fish $\mathrm{Hg}$ concentrations are not always indicative of wildlife exposure to $\mathrm{Hg}$; therefore, the $\mathrm{BOG}$ surveys could not address whether wildlife were at risk due to $\mathrm{Hg}$-induced reproductive impairment in these lakes.

We used western grebes (Aechmophorus occidentalis) and Clark's grebes (Aechmophorus clarkii) as our index of wildlife exposure to $\mathrm{Hg}$ in California lakes. Grebes are widely distributed in lakes throughout California and, as piscivorous waterbirds, are near the top of the food chain in lakes. Additionally, grebes become flightless after they arrive at their summer locations. Thus, grebes are useful representatives for wildlife risk from local, lake-specific contaminant exposure. Grebes also breed at many lakes throughout California, making them susceptible to impaired reproduction due to local Hg contamination.

We developed a tool for estimating wildlife and sport fish risk from $\mathrm{Hg}$ exposure based on $\mathrm{Hg}$ concentrations in prey fish. This quantitative tool can be used to predict $\mathrm{Hg}$ concentrations in grebe blood, grebe eggs, and sport fish, thus facilitating a feasible alternative for adequately estimating wildlife exposure when more comprehensive wildlife sampling is not possible. Specifically, we sampled grebes, prey fish, and sport fish simultaneously at 25 lakes throughout California during the spring and summer of 2012 and 2013 when breeding birds are particularly vulnerable to $\mathrm{Hg}$-induced reproductive impairment. We selected lakes based on a combination of factors, including lakes

(1) from southern and northern California,

(2) of various sizes, shapes, and elevations,

(3) with a range of sport fish $\mathrm{Hg}$ exposure levels (Davis and others, 2010),

(4) where largemouth bass (Micropterus salmoides) was the primary sport fish, and

(5) with a history of use by grebes.

Using these factors ensured that our results are representative of a broad range of lakes and reservoirs in California and are comparable to prior BOG studies.

Specifically, we addressed three management questions:

1. Does methylmercury pose significant risks to aquatic life in a representative sample of California lakes and reservoirs?

2. Can a correlational approach be applied on a statewide basis to estimate risks to birds?

3. What are appropriate water-quality monitoring requirements to address methylmercury exposure in wildlife? 


\section{Methods}

\section{Grebe Sampling}

We conducted this study at 25 lakes and reservoirs (hereafter termed lakes) throughout California during 2012 and 2013 (fig. 1). To sample grebes, sport fish, and prey fish during the summer breeding season at all 25 lakes, we sampled 13 lakes in 2012 and 12 lakes in 2013 from April through October (table 1). We captured an average of 14 grebes per lake (range: 2-38 grebes) with nightlighting techniques (King and others, 1994; Whitworth and others, 1997). Briefly, we shined a highpowered spotlight at grebes, which sometimes can disorient the bird long enough for capture with a long-handled net from a moving boat. We held birds in individual animal crates lined with towels (Plastic Pet Carrier, C Specialties, Inc., Indianapolis, Indiana, USA) until processing, and we released them near the site of capture. Clark's grebes and western grebes were differentiated by plumage. We weighed each grebe with a digital bench scale (Ohaus ES6R, Ohaus Corporation, Parsippany, New York, USA) or spring scale (Pesola Spring Scales, Pesola Ag, Baar, Switzerland). We measured the distance from the back of the bird's head to the tip of the culmen, short tarsus length (tarsometatarus bone), and culmen depth at the proximal end of the nares with digital calipers (Fowler electronic digital calipers, Newton, Massachusetts, USA). We measured flattened wing length with a wing board. We described wing molt by classifying each of the 10 primary feathers on the right wing with a value from 0 through $5-0$ represented an old feather grown the prior year; 1 represented a missing feather or a new feather that had not yet emerged from the feather quill; 2 represented a new feather less than one-third the length of a fully grown feather; 3 represented a new feather between one-third and two-thirds the length of a fully grown feather; 4 represented a new feather greater than two-thirds the length of a fully grown feather; and 5 represented a new, fully grown feather. We banded each bird with stainless steel U.S. Geological Survey leg bands to identify recaptures. We then collected whole blood $(\leq 3.0 \mathrm{~mL})$ from each bird via the brachial or jugular vein with heparinized 23-26-gauge needles and a syringe. Whole blood was immediately transferred to polypropylene cryovials, held on wet ice while in the boat, and then transferred to a liquid nitrogen storage chamber within 6 hours of collection. Blood was then transferred to the laboratory for storage at $-20^{\circ} \mathrm{C}$ until mercury analysis. We also collected a drop of blood from each grebe to determine sex through genetic analysis (Zoogen Services, Davis, California, USA).

We collected a mean of 14 grebe eggs (range: 6-23 eggs) at 7 of the 25 lakes where we sampled grebe blood (table 2). We randomly collected one egg from each nest. When possible, we identified whether the egg was that of a western grebe or a Clark's grebe by observing the incubating bird prior to collection and we classified each collected egg as either randomly sampled from an active nest (random egg) or salvaged from a nest that had been abandoned before our visit (abandoned egg). Because the parents were no longer present at abandoned nests, abandoned eggs could not be identified to species of Aechmophorus grebe. We floated eggs to determine embryo age (Ackerman and Eagles-Smith, 2010) and estimated nest initiation date by subtracting the clutch size and embryo age from the date the nest was visited.

We stored eggs on wet ice in the field and transferred them to a refrigerator until dissection. During egg dissection, we measured length and breadth of each egg to the nearest $0.01 \mathrm{~mm}$ with digital calipers (Fowler, Newton, Massachusetts, USA) and measured total egg weight to the nearest $0.01 \mathrm{~g}$ on a digital balance (Ohaus Adventurer Pro, Ohaus Corporation, Pine Brook, New Jersey, USA). We then cut an approximately $20 \mathrm{~mm}$ diameter hole in the top (air-cell end) of each egg using clean, stainless steel scissors and removed the embryo and any remaining contents into a sterile $125 \mathrm{~mL}$ jar with stainless steel forceps. We then stored the egg contents at $-20{ }^{\circ} \mathrm{C}$ until mercury determination. 


\section{Fish Sampling}

Within an average of 11 days from the date of grebe blood sampling (range: 19 days before to 79 days after grebe sampling), we returned to each of the 25 lakes to sample prey fish and sport fish at the locations where grebes were sampled. Fish were captured via electrofishing boat (Smith-Root, Vancouver, Washington, USA) and dip nets. We collected small fish in the size range (mean: $58 \mathrm{~mm}$ standard length, range: 18-123 mm) that grebes commonly consume (Lawrence, 1950). Efforts were made to sample the same species across all lakes; when this was not possible, we sampled fish that overlapped in trophic guild (table 3). We sampled 10 individuals from each of two prey fish species from each lake, for a total of 20 prey fish per lake, with four exceptions - at three lakes we sampled 25 prey fish (10 each of two species and 5 of a third species at two lakes; and 10, 8, and 7 for each of three species at one lake) and at one lake we sampled only 10 prey fish of a single species. In total, we sampled 505 prey fish of 14 species from 25 lakes (table 4). For sport fish, we collected the most common species (table 5) at each lake, within the size range commonly consumed by humans (mean: $397 \mathrm{~mm}$ total length; range: $178-726 \mathrm{~mm}$ ). We sampled 10 individuals from the most common sport fish species in each lake, with three exceptions - at two lakes we sampled only 8 sport fish and at one lake we were only able to collect 4 sport fish of 2 different species. In total, we sampled 230 sport fish of 5 species from 24 lakes (Tule Lake was not sampled for sport fish; table 6). We stored fish on wet ice in the field until processing. During fish processing, we weighed each fish with a digital balance (prey fish: Smart Weigh Pro Pocket Scale, Smart Weigh, Nanuet, New York, USA; sport fish: Angyo Portable Electronic Scale, Angyo, China) and measured standard length (prey fish) or total length (sport fish) with a fish board. Thereafter, fish were stored on dry ice until they were transferred to a freezer $(-20$ ${ }^{\circ} \mathrm{C}$ ), where they were stored until mercury determination.

\section{Mercury Determination}

We used total mercury ( $\mathrm{THg}$ ) concentrations as an index of methylmercury $(\mathrm{MeHg})$ concentrations because most of the $\mathrm{Hg}$ in fish and birds is in the more toxic $\mathrm{MeHg}$ form (Wiener and others, 2003; Ackerman and others, 2013). THg concentrations were determined on a Milestone DMA80 Direct Mercury Analyzer (Milestone, Monroe, Connecticut, USA) or a Nippon MA-3000 Direct Mercury Analyzer (Nippon Instruments North America, College Station, Texas, USA) following Environmental Protection Agency Method 7473 (U.S. Environmental Protection Agency, 2000), using an integrated sequence of drying, thermal decomposition, catalytic conversion, and then amalgamation, followed by atomic absorption spectroscopy. THg concentrations were determined at three different laboratories depending on tissue type:

1. Bird eggs were analyzed at the U.S. Geological Survey, Dixon Field Station Environmental Mercury Laboratory (Dixon, California),

2. Bird blood was analyzed at the U.S. Geological Survey, Corvallis Field Station Environmental Mercury Laboratory (Corvallis, Oregon), and

3. Fish were analyzed at Moss Landing Marine Laboratories (Moss Landing, California).

Before THg analysis, tissues were processed in the following manner. We determined $\mathrm{THg}$ concentrations in whole blood, egg contents (without the eggshell), whole-body prey fish, and muscle fillets of sport fish. For bird blood, we determined THg concentrations on a wet-weight basis. We thawed blood to room temperature, then homogenized it in a vortexer before weighing the blood for $\mathrm{THg}$ determination. For bird eggs, we dried the entire egg contents at $50{ }^{\circ} \mathrm{C}$ for $48-72 \mathrm{~h}$ until completely dried, reweighed egg contents to determine moisture content, and then homogenized the dried egg contents to a powder in a grinder with stainless steel blades. For prey fish, whole fish were washed in deionized water and manually scrubbed to remove any debris from the fish surface, dried at 
$50{ }^{\circ} \mathrm{C}$ for approximately $48 \mathrm{~h}$ until completely dried, reweighed to determine moisture content, and then homogenized to a fine powder with a porcelain mortar and pestle. For sport fish, we filleted the fish and used a small aliquot of muscle to determine $\mathrm{THg}$ concentrations on a wet-weight basis.

We report $\mathrm{THg}$ concentrations on a dry-weight (dw) basis for prey fish and sport fish, on a wet weight (ww) basis for bird blood, and on a fresh wet-weight basis (fww) for eggs. THg concentrations in sport fish were estimated on a dry-weight basis from individual-specific moisture content values and wet-weight THg concentrations. THg concentrations in eggs were estimated on a fresh wet weight basis using individual-specific moisture content of egg contents and egg morphometrics following the methods of Ackerman and others (2013). Moisture content (mean \pm SE) was $75.9 \pm 0.14$ percent in bird blood (2013 only; $n=149$; range: $71.2-80.8$ percent), $75.5 \pm 0.14$ percent in bird eggs ( $n=101$; range: 71.7-77.9 percent), 75.8 \pm 0.11 percent in prey fish $(n=505$; range: $50.4-87.5$ percent $)$, and $78.3 \pm 0.15$ percent in sport fish ( $n=230$; range: $69.7-85.2$ percent). For comparison with toxicity benchmarks developed on a wet weight basis, we also calculated wet-weight $\mathrm{THg}$ concentrations for prey fish based on individual moisture content.

Quality assurance measures included analyses of at least two certified reference materials (either dogfish muscle tissue [DORM], dogfish liver [DOLT], or lobster hepatopancreas [TORT] certified by the National Research Council of Canada, Ottawa, Canada), two system and method blanks, three continuing calibration verifications, two duplicates, and two spiked duplicates per batch. Recoveries (mean \pm SD) for blood samples were $99.2 \pm 0.4$ percent $(n=34)$ for certified reference materials, $99.2 \pm 0.5$ percent $(n=52)$ for calibration verifications, and $101.7 \pm 1.0$ percent $(n=26)$ for matrix spikes. Absolute relative percent difference for blood samples averaged $4.7 \pm 1.1$ percent $(n=22)$ for duplicates and 4.6 \pm 1.4 percent $(n=13)$ for matrix spike duplicates. Recoveries (mean \pm SD) for egg samples were $100.0 \pm 4.3$ percent $(n=28)$ for certified reference materials, $98.1 \pm 2.2$ percent $(n=32)$ for calibration verifications, and $99.0 \pm 1.8$ percent $(n=24)$ for matrix spikes. Absolute relative percent difference for egg samples averaged $3.1 \pm 1.7$ percent $(n=21)$ for duplicates and $1.3 \pm 1.0$ percent $(n=12)$ for matrix spike duplicates. Recoveries (mean \pm SD) for prey fish samples were $96.3 \pm 4.8$ percent $(n=27)$ for certified reference materials, $97.0 \pm 6.6$ percent $(n=10)$ for calibration verifications, and $96.2 \pm 11.4$ percent $(n=54)$ for matrix spikes. Absolute relative percent difference for prey fish averaged 8.0 \pm 6.5 percent $(n=27)$ for duplicates and $4.1 \pm 3.8$ percent $(n=27)$ for matrix spike duplicates. Recoveries $($ mean \pm SD) for sport fish samples were $95.0 \pm 5.9$ percent $(n=16)$ for certified reference materials, $96.1 \pm 7.0$ percent $(n=57)$ for calibration verifications, and $97.7 \pm 8.1$ percent $(n=32)$ for matrix spikes. Absolute relative percent difference for sport fish averaged 5.6 \pm 6.0 percent $(n=16)$ for duplicates and $4.9 \pm 3.3$ percent $(n=16)$ for matrix spike duplicates.

\section{Statistical Methods}

\section{Mercury by Lake}

In the first stage of our analyses, we used linear mixed-effect models to estimate least squares mean THg concentrations in grebe blood, grebe eggs, prey fish, and sport fish for each lake. To do so, we developed a separate model for each tissue type that incorporated several variables that we could not completely control during field sampling. These potential sampling biases included species and sex of grebes (blood), species and type of grebe eggs collected (random or abandoned eggs), and species and length of fish. For grebe blood, $\log _{\mathrm{e}}$-transformed THg concentration $(\mu \mathrm{g} / \mathrm{g} \mathrm{ww})$ was the dependent variable, species (western grebe or Clark's grebe) and sex (male or female) were fixed effects, and lake was a random effect. For grebe eggs, $\log _{\mathrm{e}}$-transformed $\mathrm{THg}$ concentration $(\mu \mathrm{g} / \mathrm{g}$ fww) was the dependent variable, species (western grebe, Clark's grebe, or unknown) and egg collection type (random or abandoned) were fixed effects, and lake was a random effect. For prey fish, $\log _{\mathrm{e}}$-transformed $\mathrm{THg}$ 
concentrations $(\mu \mathrm{g} / \mathrm{g} \mathrm{dw})$ was the dependent variable; species, standard length, and species $\times$ length interaction were fixed effects; and lake was a random effect. The sport fish model was similar to the prey fish model, except that total length was used instead of standard length. For all four response variables, least squares means were estimated for each lake from the mixed-effect models using Best Linear Unbiased Predictors in JMP ${ }^{\circledR}$ software (version 11.2.0; SAS Institute, Inc., Cary, North Carolina, USA). The least squares mean THg concentrations in prey fish for each lake were then used as a covariate in the next analyses describing factors influencing $\mathrm{THg}$ concentrations in grebe blood, grebe eggs, and sport fish. Lastly, the least squares mean THg concentrations in grebe blood, grebe eggs, and sport fish for each lake were used in linear regression analyses to assess the relationships among these three tissues.

\section{Factors Influencing Mercury in Grebes and Sport Fish}

In the next stage of our analyses, we used linear mixed-effect models to examine which variables influenced THg concentrations in grebe blood, grebe eggs, and sport fish. For each of these tissues, we built a set of candidate models based on potential predictor variables describing the (1) specific tissue, (2) lake attributes, and (3) THg concentrations in prey fish. For each of the three tissue types, the model structure was similar except for the variables describing the specific tissue.

For grebe blood, the potential tissue-specific predictor variables included species (western grebe or Clark's grebe), sex (male or female), bird mass, body condition index, linear (wing molt) and quadratic (wing molt ${ }^{2}$ ) terms for wing molt score, and linear (date) and quadratic (date ${ }^{2}$ ) terms for sampling date. We did not allow bird mass and body condition to occur in the same model. Year was not included because each lake was sampled in only 1 of the 2 years. The body condition index was estimated as an individual's residual mass divided by its mass, where an individual's residual mass was calculated as the residual from a linear regression model of bird mass and structural body size. Structural body size of birds was calculated using a principal components analysis (PCA) of three structural body size measurements (length in millimeters of back of head to tip of culmen, short tarsus, and culmen depth) for each grebe species and sex. The PCA indicated that structural body size measurements were correlated as expected, and the first principal component (PC1) accounted for 54 percent (male) and 50 percent (female) of the morphological variation in western grebes and 56 percent (male) and 51 percent (female) of the morphological variation in Clark's grebes. Eigenvector weights of PC1 were positive and ranged from 0.41 to 0.67 (male) and 0.47 to 0.64 (female) for western grebes and from 0.50 to 0.63 (male) and 0.55 to 0.59 (female) for Clark's grebes. Wing molt was calculated as the mean value of molt classification for each of the 10 primary feathers. Finally, date was standardized as the difference between the day of year the bird was captured and the median day of year for all captured birds (median day of year was 181 for June 29 in 2012 and June 30 in 2013).

For grebe eggs, the potential tissue-specific predictor variables included species (western grebe, Clark's grebe, or unknown Aechmophorus grebe), egg collection type (random or abandoned), date, and date $^{2}$. Again, date was standardized as the difference between the day of year the nest was initiated and the median day of year for all nests initiated (median day of year was 211). For sport fish, the potential tissue-specific predictor variables included taxa (largemouth bass [Micropterus salmoides], smallmouth bass [Micropterus dolomieu], rainbow trout [Oncorhynchus mykiss], brown trout [Salmo trutta], and Eagle Lake rainbow trout [a subspecies of rainbow trout; Oncorhynchus mykiss aquilarum]), total length, and species $\times$ total length interaction. Date was standardized as the difference between day of year the sport fish were captured and the median day of year for all captured sport fish (median day of year was 204). 
For each of the three tissue types, the candidate model set included several lake-specific variables, including lake area (hectares), lake perimeter (kilometers), lake shape index, and elevation (meters). For each lake, we obtained the lake attribute data (table 7) from the U.S. Geological Survey National Hydrography Dataset (http://nhd.usgs.gov) and the California Department of Fish and Wildlife (ftp://ftp.dfg.ca.gov/BDB/GIS/California_Lakes). The lake shape index was calculated using the following equation where a larger shape index indicates a lake with more shoreline relative to the lake's size (McGarigal, 2014):

$$
\text { Lake Shape Index }=\frac{0.25 \times \text { Perimeter }(m)}{\sqrt{\text { Lake Area }\left(m^{2}\right)}}
$$

Lastly, we evaluated the influence of both lake-specific least squares mean $\log _{\mathrm{e}}$-transformed $\mathrm{THg}$ concentrations in prey fish and lake-specific geometric mean $\log _{\mathrm{e}}$-transformed $\mathrm{THg}$ concentrations in prey fish on THg concentrations in grebe blood, grebe eggs, and sport fish, with the rule that both least squares mean and geometric mean THg concentrations in prey fish could not be included in the same model. For each of the three tissue types, models including least squares mean $\mathrm{THg}$ concentrations in prey fish, which statistically accounted for prey-fish length and species, performed substantially better than models including geometric mean THg concentrations in prey fish. The best model that included least squares mean THg concentrations in prey fish was 5.9, 6.8, and 30.3 times more likely than the best model that included geometric mean $\mathrm{THg}$ concentrations in prey fish for grebe blood, grebe eggs, and sport fish, respectively (all $\Delta \mathrm{AIC} c>3.55$ ). Therefore, geometric mean $\mathrm{THg}$ concentrations in prey fish was removed as a potential variable in the final candidate model sets. 
For each of the three tissue types, our final candidate model set included all additive combinations of variables (except where previously noted) and a null model (a total of 3,456 models for grebe blood, 384 for grebe eggs, and 480 for sport fish). In each model, $\log _{\mathrm{e}}$-transformed $\mathrm{THg}$ concentration was the dependent variable and lake was included as a random effect. We evaluated models using second-order Akaike Information Criterion ( $\mathrm{AICc}$ ) and considered the model with the smallest $\mathrm{AIC} c$ to be the most parsimonious (Burnham and Anderson, 2002). We used $\mathrm{AIC}_{c}$ differences between the best model and each of the other candidate models $(\triangle \mathrm{AIC} c)$ to determine the relative ranking of each model. For biological importance, we considered models for which $\Delta \mathrm{AIC} c \leq 2$. We used Akaike weights $\left(w_{i}\right)$ to examine the weight of evidence that the selected model was the best model within the set of candidate models. We used evidence ratios to compare the relative weight of support between models. We also assessed the relative importance of each variable by summing Akaike weights across models that incorporated the same variable. Because the variables were not completely balanced in the candidate model set, and therefore had different prior variable weights, we further adjusted this relative variable importance by comparing the difference in final (or posterior) relative variable weight with its initial (or prior) weighting. Prior weighting represents the expected variable weight if all models in the candidate model set were equally weighted and was calculated as the proportion of models within the candidate model set in which a given variable was present. Adjusted relative variable importance was thus calculated as the log-odds ratio of the posterior and prior variable weights. Adjusted relative variable importance values that exceeded 0 had posterior weights that were greater than was expected by their prior weighting and were considered to be important, and values less than 0 had posterior weights that were less than was expected by their prior weighting and were considered to be unimportant. The adjusted relative variable importance equation was described as follows:

$$
\text { Adjusted Relative Variable Importance }=\log \left[\frac{\left(\frac{P}{1-P}\right)}{\left(\frac{P_{0}}{1-P_{0}}\right)}\right]
$$

where,

$$
\begin{aligned}
& P=\text { Posterior Variable Weight } \\
& P_{0}=\text { Prior Variable Weight }
\end{aligned}
$$

For brevity in the tables, we present only the set of best models that were within $\triangle \mathrm{AIC} c \leq 2$, the null model, and each model that was similar to the best model except one of the variables in the best model was removed. When examining effects of a specific variable, we estimated conditional modelaveraged coefficients by only model-averaging across models where the variable was present, to better reflect the true relationship of $\mathrm{THg}$ concentrations with that variable. However, all other results were based on model-averaged predictions and standard errors from the full candidate model set. We report back-transformed least squares means and estimated standard errors using the delta method (Seber, 1982).

All data in this report are available to be accessed with the authors' permission via the California Environmental Data Exchange Network (CEDEN). 


\section{Results and Discussion}

\section{Mercury Concentrations among Lakes}

We captured 354 grebes at 25 lakes and determined their THg concentrations in blood; 71 percent were western grebes and 29 percent were Clark's grebes, and 48 percent were female and 52 percent were male (table 1). THg concentrations in grebe blood differed between species $\left(F_{1,331.3}=13.35\right.$, $p<0.001)$ and sexes $\left(F_{1,328.5}=12.58, p<0.001\right.$; fig. 2$)$. Least squares mean THg concentrations in grebe blood ranged from 0.16 $\pm 0.02 \mu \mathrm{g} / \mathrm{g} w \mathrm{w}$ at Big Lake to $5.16 \pm 0.61 \mu \mathrm{g} / \mathrm{g}$ ww at Lake Berryessa (fig. 3).

We collected 101 grebe eggs at seven lakes and analyzed them for THg concentrations (table 2); 62 percent were western grebes, 15 percent were Clark's grebes, and 23 percent were unknown Aechmophorus grebes. THg concentrations in grebe eggs did not differ between species $\left(F_{2,92.31}=0.64\right.$, $p=0.53)$ or egg collection status $\left(F_{1,92.06}=2.10, p=0.15\right)$. Least squares mean $\mathrm{THg}$ concentrations in grebe eggs ranged from $0.03 \pm 0.01 \mu \mathrm{g} / \mathrm{g}$ fww at Big Lake to $0.15 \pm 0.02 \mu \mathrm{g} / \mathrm{g}$ fww at Clear Lake (fig. 3). (Note: Although we analyzed another 23 abandoned grebe eggs for THg concentrations and uploaded these data into the CEDEN database, we eventually excluded these eggs from statistical analyses because we could not adequately account for sibling eggs collected from the same nest because the correctly structured statistical model with nest number as a random effect [to account for potential pseudoreplication of the same parent] would not converge.)

We analyzed $\mathrm{THg}$ concentrations in 505 prey fish of 14 species from 25 lakes: 30 percent bluegill (Lepomis macrochirus), 22 percent Mississippi silverside (Menidia audens), 14 percent threadfin shad (Dorosoma petenense), 8 percent golden shiner (Notemigonus crysoleucas), 5 percent Sacramento perch (Archoplites interruptus), 4 percent tui chub (Gila bicolor), 4 percent Sacramento sucker (Catostomus occidentalis), and 2 percent each of blue chub (Gila coerulea), hitch (Lavinia exilicauda), largemouth bass, pumpkinseed (Lepomis gibbosus), redear sunfish (Lepomis microlophus), smallmouth bass, and Tahoe sucker (Catostomus tahoensis) (tables 3 and 4). THg concentrations in prey fish differed among species $\left(F_{13,374.7}=9.90, p<0.0001\right)$ while accounting for standard length $\left(F_{1,455.1}=2.86, p=0.09\right)$, and there was a significant species $\times$ standard length interaction $\left(F_{13,459.1}=11.13\right.$, $p<0.0001)$. Least squares mean THg concentrations were highest in blue chub $(0.25 \pm 0.14 \mu \mathrm{g} / \mathrm{g} \mathrm{dw})$, hitch $(0.24 \pm 0.07 \mu \mathrm{g} / \mathrm{g} \mathrm{dw})$, and silverside $(0.23 \pm 0.05 \mu \mathrm{g} / \mathrm{g} \mathrm{dw})$, and lowest in smallmouth bass $(0.04 \pm 0.02 \mu \mathrm{g} / \mathrm{g} \mathrm{dw}$; fig. 4). Least squares mean $\mathrm{THg}$ concentrations in prey fish ranged from $0.03 \pm 0.01$ $\mu \mathrm{g} / \mathrm{g} \mathrm{dw}$ at Eagle Lake to $0.70 \pm 0.18 \mu \mathrm{g} / \mathrm{g} \mathrm{dw}$ at Bridgeport Reservoir (fig. 3).

We analyzed THg concentrations in 230 sport fish of 5 species from 24 lakes - 68 percent largemouth bass, 17 percent rainbow trout, 5 percent smallmouth bass, 5 percent brown trout, and 4 percent Eagle Lake rainbow trout (tables 5 and 6). THg concentrations in sport fish differed among species $\left(F_{4,27.52}=9.02, p<0.0001\right)$ and increased with total length $\left(F_{1,208.4}=30.05, p<0.0001\right)$, while accounting for the potential species $\times$ total length interaction $\left(F_{4,210.5}=1.77, p=0.14\right)$. Least squares mean $\mathrm{THg}$ concentrations were highest in smallmouth bass $(2.33 \pm 1.10 \mu \mathrm{g} / \mathrm{g} \mathrm{dw})$ and lowest in Eagle Lake rainbow trout $(0.10 \pm 0.07 \mu \mathrm{g} / \mathrm{g} \mathrm{dw}$; fig. 4). Least squares mean $\mathrm{THg}$ concentrations in sport fish ranged from $0.20 \pm 0.06 \mu \mathrm{g} / \mathrm{g} \mathrm{dw}$ at Perris Reservoir to $2.12 \pm 0.63 \mu \mathrm{g} / \mathrm{g}$ dw at Lake Berryessa (fig. 3).

\section{Factors Influencing Mercury in Grebe Blood}

The most parsimonious model describing THg concentrations in grebe blood included least squares mean THg concentrations in prey fish, grebe species, grebe sex, wing molt index, and lake perimeter (table 8). Fifteen other models were within $\triangle \mathrm{AIC} c \leq 2.0$, and all included the variables least squares mean THg concentrations in prey fish, grebe species, and grebe sex. In fact, all models containing these three variables had a cumulative Akaike weight of 0.97 , indicating their importance. 
The other variables that appeared with these three primary variables in models within $\Delta \mathrm{AIC} c \leq 2.0$ included date, date ${ }^{2}$, wing molt index ${ }^{2}$, grebe body condition index, lake shape index, and lake area. However, these additional variables did not improve model fit and were considered to be uninformative parameters (Arnold, 2010). We estimated the relative importance of individual variables and found that the data strongly supported the effects of least squares mean $\mathrm{THg}$ concentrations in prey fish (adjusted relative variable importance $=14.4$ ), species (5.8), and sex (3.5), with some support for lake perimeter (1.2). In contrast, the adjusted relative variable importance for the remaining variables were all less than 0 .

To further determine the importance of variables in the best model, we compared the best model to the same model structure but omitted one of the variables. Using this evidence ratio approach, we estimated that the best model that included least squares mean $\mathrm{THg}$ concentrations in prey fish was $2.47 \times 10^{6}$ times more likely than the same model without the effect of least squares mean $\mathrm{THg}$ concentrations in prey fish. Similarly, the best model was 428 times more likely than the same model without grebe sex, 318 times more likely than the same model without grebe species, 5.5 times more likely than the same model without lake perimeter, and only 1.03 times more likely than the same model without wing molt index. The null model (with lake as a random effect) was not supported ( $\triangle \mathrm{AIC} c=$ $\left.53.08 ; w_{i}=0.00\right)$, and the best model was $3.36 \times 10^{11}$ times more likely than the null model. Modelaveraged estimates of each variable's beta coefficients are presented in the equations in section, "Predictive Equations."

The conditional model-averaged coefficients indicated that each $1.0 \mu \mathrm{g} / \mathrm{g} \mathrm{dw}$ (approximately $0.24 \mu \mathrm{g} / \mathrm{g} \mathrm{ww}$ ) increase in THg concentrations in prey fish results in a 103 percent increase in $\mathrm{THg}$ concentrations in grebe blood. Predicted THg concentrations in grebe blood increased by 824 percent $^{1}$ (from 0.26 to $2.37 \mu \mathrm{g} / \mathrm{g} \mathrm{ww}$ ) over the observed range of THg concentrations in prey fish among lakes $(0.03 \pm 0.01 \mu \mathrm{g} / \mathrm{g} \mathrm{dw}$ at Eagle Lake to $0.70 \pm 0.18 \mu \mathrm{g} / \mathrm{g} \mathrm{dw}$ at Bridgeport Reservoir; fig. 5). Least squares mean THg concentrations in blood were 27 percent higher in Clark's grebes $(0.78 \pm 0.10 \mu \mathrm{g} / \mathrm{g} \mathrm{ww})$ than in western grebes $(0.61 \pm 0.07 \mu \mathrm{g} / \mathrm{g} \mathrm{ww})$, and 22 percent higher in males $(0.77 \pm 0.10 \mu \mathrm{g} / \mathrm{g} \mathrm{ww})$ than in females $(0.63 \pm 0.08 \mu \mathrm{g} / \mathrm{g} \mathrm{ww})$. Lastly, conditional model-averaged coefficients indicated that $\mathrm{THg}$ concentrations in grebe blood increased by 0.5 percent with each $1 \mathrm{~km}$ increase in lake perimeter.

\section{Factors Influencing Mercury in Grebe Eggs}

The most parsimonious model describing THg concentrations in grebe eggs included least squares mean THg concentrations in prey fish, date, and lake perimeter (table 9). Fifteen other models were within $\triangle \mathrm{AIC} c$ less than or equal to 2.0. The other variables that appeared in models within $\Delta \mathrm{AIC} c$ $\leq 2.0$ included lake area, lake shape index, egg collection type, and date ${ }^{2}$, but these additional variables were considered to be uninformative parameters (Arnold, 2010). We estimated the relative importance of individual variables and found that the data supported only the effects of least squares mean $\mathrm{THg}$ concentrations in prey fish (adjusted relative variable importance $=1.9$ ) because the adjusted relative variable importance for the remaining variables were all less than 0 .

Using evidence ratios, we estimated that the best model, which included least squares mean $\mathrm{THg}$ concentrations in prey fish, was 40 times more likely than the same model without the effect of $\mathrm{THg}$ concentrations in prey fish. Similarly, the best model was only 1.4 times more likely than the same model without lake perimeter and 1.3 times more likely than the same model without date. The null model (with lake as a random effect) was not supported $\left(\triangle \mathrm{AIC} c=8.63 ; w_{i}=0.00\right)$, and the best model was 74.7 times more likely than the null model.

\footnotetext{
${ }^{1}$ All percentages were calculated using unrounded Hg concentrations, and will therefore differ slightly with those that might be calculated by readers using the rounded mean values presented.
} 
Similar to THg concentrations in grebe blood, conditional model-averaged coefficients indicated that each $1.0 \mu \mathrm{g} / \mathrm{g} \mathrm{dw}$ increase in $\mathrm{THg}$ concentrations in prey fish results in a 92 percent increase in $\mathrm{THg}$ concentrations in grebe eggs. Predicted THg concentrations in grebe eggs increased by 500 percent (from 0.04 to $0.24 \mu \mathrm{g} / \mathrm{g}$ fww) over the observed range of THg concentrations in prey fish among lakes (fig. 5).

\section{Factors Influencing Mercury in Sport Fish}

The most parsimonious model describing THg concentrations in sport fish included least squares mean $\mathrm{THg}$ concentrations in prey fish, sport fish species, sport fish total length, lake elevation, lake area, and a sport fish species $\times$ total length interaction (table 10). Five other models were within $\triangle \mathrm{AIC} c$ $\leq 2.0$, and all included the variables least squares mean $\mathrm{THg}$ concentrations in prey fish, sport fish species, sport fish length, and a sport fish species $\times$ total length interaction. In fact, all models containing these variables had a cumulative Akaike weight of 0.89. The other variables that appeared with these primary variables in models within $\triangle \mathrm{AIC} c \leq 2.0$ included lake perimeter, lake shape, and date, but these additional variables were considered to be uninformative parameters (Arnold, 2010). We estimated the relative importance of individual variables and found that the data strongly supported the effects of sport fish total length (adjusted relative variable importance $>36$ ), least squares mean $\mathrm{THg}$ concentrations in prey fish (8.3), lake elevation (4.1), sport fish species (2.0), and sport fish species $\times$ total length interaction (3.5), with a little support for lake area (0.2). In contrast, the adjusted relative variable importance for the remaining variables were all less than 0 .

Using evidence ratios, we estimated that the best model, which included least squares mean $\mathrm{THg}$ concentrations in prey fish, was $1.71 \times 10^{5}$ times more likely than the same model without the effect of $\mathrm{THg}$ concentrations in prey fish. Similarly, the best model was $4.18 \times 10^{28}$ times more likely than the same model without sport fish length and the sport fish species $\times$ length interaction, 49.1 times more likely than the same model without lake elevation, 44.9 times more likely than the same model without the sport fish species $\times$ length interaction, 17.3 times more likely than the same model without sport fish species and the sport fish species $\times$ length interaction, and only 1.2 times more likely than the same model without lake area. The null model (with lake as a random effect) was not supported ( $\triangle \mathrm{AIC} c=$ $181.19 ; w_{i}=0.00$ ), and the best model was $2.21 \times 10^{39}$ times more likely than the null model.

The conditional model-averaged coefficients indicated that each $1.0 \mu \mathrm{g} / \mathrm{g} \mathrm{dw}$ increase in $\mathrm{THg}$ concentrations in prey fish results in a 116 percent increase in $\mathrm{THg}$ concentrations in sport fish. Predicted THg concentrations in sport fish increased by 1,023 percent (from 0.20 to $2.21 \mu \mathrm{g} / \mathrm{g} \mathrm{dw}$ ) over the observed range of THg concentrations in prey fish among lakes (fig. 5). With each $10 \mathrm{~cm}$ increase in total length of sport fish, conditional model-averaged coefficients indicated that THg concentrations in sport fish increased by 239 percent for Eagle Lake rainbow trout, 102 percent for largemouth bass, 93 percent for rainbow trout, 80 percent for smallmouth bass, and 21 percent for brown trout. Least squares mean $\mathrm{THg}$ concentrations in sport fish were highest in smallmouth bass $(1.97 \pm 0.67 \mu \mathrm{g} / \mathrm{g} \mathrm{dw})$, followed by largemouth bass $(1.30 \pm 0.19 \mu \mathrm{g} / \mathrm{g} \mathrm{dw})$, rainbow trout $(0.55 \pm 0.18 \mu \mathrm{g} / \mathrm{g} \mathrm{dw})$, Eagle Lake rainbow trout $(0.45 \pm 0.29 \mu \mathrm{g} / \mathrm{g} \mathrm{dw})$, and brown trout $(0.38 \pm 0.15 \mu \mathrm{g} / \mathrm{g} \mathrm{dw})$. Lastly, conditional model-averaged coefficients indicated that THg concentrations in sport fish decreased by 28 percent with each $0.5 \mathrm{~km}$ increase in the lake's elevation. 


\section{Predictive Equations}

\section{Grebe Blood}

$\mathrm{THg}$ concentrations in grebe blood $(\mu \mathrm{g} / \mathrm{g}$ ww) can be estimated using model-averaged coefficients from our full candidate model set:

$$
\begin{aligned}
& \ln \left(\text { BloodTHg } g_{\text {Grebe }}\right)= \\
& \beta_{0}+0.706\left(\ln \left(\overline{T H g}_{\text {preyfish }}\right)\right)+0.000408(\text { DayofYear }-181) \\
& -0.0000258(\text { DayofYear }-181)^{2}+0.00416\left(\text { LakePerimeter }_{k m}\right) \\
& -0.00000270\left(\text { LakeArea }_{h a}\right)-0.0496(\text { LakeShapeIndex }) \\
& -0.0000250\left(\text { LakeElevation }_{m}\right)
\end{aligned}
$$

where,

$\beta_{0}$ is a species and sex-specific coefficient that incorporates the potential effects of bird mass, body condition, and wing molt score.

To uniquely predict $\mathrm{THg}$ concentrations by grebe species and sex, $\beta_{0}$ can be estimated using one of these four equations:

Western grebe females:

$\beta_{0}=0.811+0.0000216($ Mass $)-0.0698($ Molt $)+0.00897\left(\right.$ Molt $\left.^{2}\right)-0.0151$ (BodyCondition $)$ Western grebe males:

$$
\beta_{0}=1.01+0.0000216(\text { Mass })-0.0698(\text { Molt })+0.00897\left(\text { Molt }^{2}\right)-0.0151(\text { BodyCondition })
$$

Clark's grebe females:

$$
\left.\beta_{0}=1.05+0.0000216(\text { Mass })-0.0698(\text { Molt })+0.00897\left(\text { Molt }^{2}\right)-0.0151 \text { (BodyCondition }\right)
$$

Clark's grebe males:

$$
\beta_{0}=1.24+0.0000216(\text { Mass })-0.0698(\text { Molt })+0.00897\left(\text { Molt }^{2}\right)-0.0151(\text { BodyCondition })
$$

To estimate $\beta_{0}$ coefficient, we used species and sex-specific means, or the mode in the case of wing molt score, for each equation. Mean mass of western grebes was $1,055 \mathrm{~g}$ for females and $1,311 \mathrm{~g}$ for males. Mean mass of Clark's grebes was 1,021 $\mathrm{g}$ for females and 1,271 $\mathrm{g}$ for males. Mean body condition index of western grebes was -0.0156 for females and -0.0119 for males. Mean body condition index of Clark's grebes was -0.0109 for females and -0.00734 for males. Given the highly skewed nature of wing molt scores (87 percent of all grebes were captured prior to molt and therefore had a wing molt score of 0 ), we used the mode of molt score ( 0 ) for model prediction. Using these values, $\beta_{0}$ was estimated to be 0.834 for female western grebes, 1.04 for male western grebes, 1.07 for female Clark's grebes, and 1.27 for male Clark's grebes.

Often, model users will have no knowledge about the species and sex composition of grebes within the lake of interest. Therefore, we can simplify this equation even further by assuming equal composition of grebes among species and sexes, and the four specific $\beta_{0}$ coefficients can be replaced with the average grebe $\beta_{0}$ coefficient of 1.05 . 
Thus, the final equation to predict THg concentrations in grebe blood is:

$$
\begin{aligned}
& \ln \left(\text { BloodTHg } g_{\text {AverageGrebe }}\right)= \\
& 1.05+0.706(\left.\ln \left(\overline{T H g}_{\text {preyfish }}\right)\right)+0.000408(\text { DayofYear }-181) \\
&-0.0000258(\text { DayofYear }-181)^{2}+0.00416\left(\text { LakePerimeter }_{k m}\right) \\
&-0.00000270\left(\text { LakeArea }_{h a}\right)-0.0496(\text { LakeShapeIndex }) \\
&-0.0000250\left(\text { LakeElevation }_{m}\right)
\end{aligned}
$$

Lastly, to estimate $\mathrm{THg}$ concentrations in grebe blood, this model equation can be exponentiated to remove the $\log _{\mathrm{e}}$-transformation used during modeling:

$$
\text { BloodTHg } g_{\text {AverageGrebe }}=
$$

$$
2.87 e^{\left(0.706\left(\ln \left(\overline{T H g}_{\text {preyfish }}\right)\right)+0.000408\left(\text { DayofYear }_{181}\right)-0.0000258(\text { DayofYear-181 })^{2}+0.00416\left(\text { LakePerimeter }_{\mathrm{km}}\right)\right.}
$$

where,

$\overline{\mathrm{THg}}_{\text {preyfish }}$ is the least squares mean $\mathrm{THg}$ concentration in prey fish, which accounts for the length and species of prey fish.

Figure 6 displays this model-averaged prediction of THg concentrations in grebe blood over the observed range of THg concentrations in individual prey fish. The panels in figure 6 show the differences among grebe species and sexes for the modeled-averaged means (top left panel) and the 95percent confidence limits around this mean for each grebe species and sex.

When lake data are not available, we can further simplify these equations by using median values for date and mean values for lake attributes. When we do so, the equations to predict $\mathrm{THg}$ concentrations in grebe blood are:

$$
\begin{gathered}
\ln \left(\text { BloodTH }_{\text {AverageGrebe }}\right)=1.11+0.706\left(\ln \left(\overline{T H g}_{\text {preyfish }}\right)\right) \\
\ln \left(\text { BloodTHg } g_{\text {AverageFemaleWesternGrebe }}\right)=0.895+0.706\left(\ln \left(\overline{T H}_{\text {preyfish }}\right)\right) \\
\ln \left(\text { BloodTHg } g_{\text {AverageMaleWesternGrebe }}\right)=1.10+0.706\left(\ln \left(\overline{T H g}_{\text {preyfish }}\right)\right) \\
\ln \left(\text { BloodTHg } g_{\text {AverageFemaleClark'sGrebe }}\right)=1.13+0.706\left(\ln \left(\overline{T H g}_{\text {preyfish }}\right)\right) \\
\ln \left(\text { BloodTHg } g_{\text {AverageMaleClark'sGrebe }}\right)=1.33+0.706\left(\ln \left(\overline{T H g}_{\text {preyfish }}\right)\right)
\end{gathered}
$$




\section{Grebe Eggs}

For predicting THg concentrations in grebe eggs $(\mu \mathrm{g} / \mathrm{g}$ fww), we implemented a similar approach and predicted models for each unique combination of grebe species (western grebe, Clark's grebe, and unknown) and egg collection type (random and abandoned). The egg-specific coefficients in the model $\left(\beta_{0}\right)$ were species, egg collection type, and nest initiation date. We assumed equal composition of Clark's grebes' and western grebes' eggs as well as random and abandoned eggs. Lastly, we used the median nest initiation date for all eggs collected (median day of year was 211). Thus, the final equation to predict $\mathrm{THg}$ concentrations in grebe eggs is:

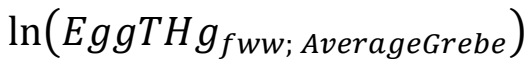

$$
\begin{aligned}
& =-1.49+0.569\left(\ln \left(\overline{T H g}_{\text {preyfish }}\right)+0.00197\left(\text { LakePerimeter }_{k m}\right)\right. \\
& \left.+0.00000846\left(\text { LakeArea }_{h a}\right)+0.0421 \text { (LakeShapeIndex }\right) \\
& \text { - 0.00000977(LakeElevation) }
\end{aligned}
$$

Figure 7 displays this model-averaged prediction of THg concentrations in grebe eggs over the observed range of THg concentrations in individual prey fish. The panels in figure 7 show the differences among grebe species and egg type for the modeled-averaged means (top left panel), and the 95-percent confidence limits around this mean. Because there was no difference in model predictions by grebe species and egg collection type, the regression lines are indistinguishable and we therefore show only the 95-percent confidence limits around this mean for randomly sampled western grebe eggs as an example.

When lake data are not available, we can further simplify these equations by using median values for date and mean values for lake attributes. When we do so, the equation to predict $\mathrm{THg}$ concentrations in grebe eggs is:

$$
\ln \left(E g g T H g_{f w w ; \text { AverageGrebe }}\right)=-1.21+0.569\left(\ln \left(\overline{T H g}_{\text {preyfish }}\right)\right.
$$

\section{Sport Fish}

For predicting $\mathrm{THg}$ concentrations in sport fish $(\mu \mathrm{g} / \mathrm{g} \mathrm{dw})$, we again implemented a similar approach and predicted models for each species of sport fish. The final equations to predict $\mathrm{THg}$ concentrations in sport fish are:

$$
\begin{aligned}
& \left.\ln \left(\text { SportFishTH } g_{\text {Averagesportfish }}\right)=-0.630+0.00621 \text { (TotalLength } \text { mm }\right) \\
& +0.768\left(\ln \left(\overline{T H g}_{\text {preyfish }}\right)\right)+0.0000205\left(\text { LakeArea }_{h a}\right) \\
& \left.-0.000658\left(\text { LakeElevation }_{m}\right)-0.000140 \text { (LakePerimeter }_{k m}\right) \\
& -0.0202(\text { LakeShapeIndex })+0.000309 \text { (DayofYear }-204) \\
& +0.00000161(\text { DayofYear }-204)^{2} \\
& \ln \left(\text { SportFishTH } g_{\text {LargemouthBass }}\right)=-0.237+0.00649\left(\text { TotalLength }_{m m}\right) \\
& +0.768\left(\ln \left(\overline{T H g}_{\text {preyfish }}\right)\right)+0.0000205\left(\text { LakeArea }_{h a}\right) \\
& \left.-0.000658\left(\text { LakeElevation }_{m}\right)-0.000140 \text { (LakePerimeter }_{k m}\right) \\
& -0.0202(\text { LakeShapeIndex })+0.000309 \text { (DayofYear }-204) \\
& +0.00000161(\text { DayofYear }-204)^{2}
\end{aligned}
$$




$$
\begin{aligned}
& \ln \left(\text { SportFishTH } g_{\text {SmallmouthBass }}\right)=0.557+0.00544\left(\text { TotalLength }_{m m}\right) \\
& +0.768\left(\ln \left(\overline{T H g}_{\text {preyfish }}\right)\right)+0.0000205\left(\text { LakeArea }_{h a}\right) \\
& \left.-0.000658\left(\text { LakeElevation }_{m}\right)-0.000140 \text { (LakePerimeter }_{k m}\right) \\
& -0.0202(\text { LakeShapeIndex })+0.000309 \text { (DayofYear }-204) \\
& +0.00000161(\text { DayofYear }-204)^{2} \\
& \ln \left(\text { SportFishTH } g_{\text {RainbowTrout }}\right)=-0.865+0.00608\left(\text { TotalLength }_{m m}\right) \\
& +0.768\left(\ln \left(\overline{T H g}_{\text {preyfish }}\right)\right)+0.0000205\left(\text { LakeArea }_{\text {ha }}\right) \\
& -0.000658\left(\text { LakeElevation }_{m}\right)-0.000140\left(\text { LakePerimeter }_{k m}\right) \\
& -0.0202(\text { LakeShapeIndex })+0.000309 \text { (DayofYear }-204) \\
& +0.00000161(\text { DayofYear }-204)^{2}
\end{aligned}
$$$$
\begin{aligned}
& \ln (\text { SportFishTH } \\
& \quad+0.0000205\left(\text { BakeArea }_{h a}\right)-0.000658\left(\text { LakeElevation }_{m}\right) \\
& \quad-0.000140\left(\text { LakePerimeter }_{k m}\right)-0.0202(\text { LakeShapeIndex }) \\
& \quad+0.000309(\text { DayofYear }-204)+0.00000161(\text { DayofYear }-204)^{2}
\end{aligned}
$$$$
\ln \left(\text { SportFishTHg } g_{\text {EagleLakeRainbowTrout }}\right)=-3.04+0.0111\left(\text { TotalLength }_{m m}\right)
$$$$
+0.768\left(\ln \left(\overline{T H g}_{\text {preyfish }}\right)\right)+0.0000205\left(\text { LakeArea }_{\text {ha }}\right)
$$$$
-0.000658\left(\text { LakeElevation }_{m}\right)-0.000140\left(\text { LakePerimeter }_{k m}\right)
$$$$
-0.0202(\text { LakeShapeIndex })+0.000309 \text { (DayofYear }-204)
$$$$
+0.00000161(\text { DayofYear }-204)^{2}
$$

Figure 8 displays this model-averaged prediction of THg concentrations in sport fish over the observed range of $\mathrm{THg}$ concentrations in individual prey fish. The panels in figure 8 show the differences among species of sport fish for the modeled-averaged means (top left panel) and the 95 percent confidence limits around this mean for each species of sport fish.

Lastly, figure 9 displays these same model-averaged predictions simultaneously for mean $\mathrm{THg}$ concentrations in grebe blood, grebe eggs, and sport fish over the observed range of $\mathrm{THg}$ concentrations in individual prey fish. For this figure, the different panels show only the differences between types of animal tissue, without the variance associated with the estimates.

When lake data are not available, we can further simplify these equations by using median values for date, $350 \mathrm{~mm}$ for total length, and mean values for lake attributes. When we do so, the equations to predict $\mathrm{THg}$ concentrations in sport fish are:

$$
\begin{aligned}
& \ln \left(\text { SportFishTH } g_{\text {AverageSportfish }}\right)=1.06+0.768\left(\ln \left(\overline{T H g}_{\text {preyfish }}\right)\right) \\
& \ln \left(\text { SportFishTHg } g_{\text {LargemouthBass }}\right)=1.56+0.768\left(\ln \left(\overline{T H g}_{\text {preyfish }}\right)\right) \\
& \ln \left(\text { SportFishTH } g_{\text {SmallmouthBass }}\right)=1.98+0.768\left(\ln \left(\overline{T H g}_{\text {preyfish }}\right)\right) \\
& \ln \left(\text { SportFishTHg } g_{\text {RainbowTrout }}\right)=0.783+0.768\left(\ln \left(\overline{T H g}_{\text {preyfish }}\right)\right) \\
& \ln \left(\text { SportFishTH } g_{\text {BrownTrout }}\right)=0.631+0.768\left(\ln \left(\overline{T H g}_{\text {preyfish }}\right)\right)
\end{aligned}
$$

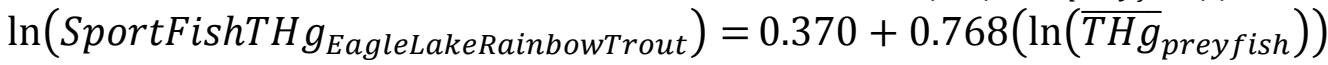




\section{Predictive Model's Fit}

We compared model-averaged predictions to our individual raw $\mathrm{THg}$ concentrations and found generally good agreement between predicted and observed data (fig. 10). Predicted THg concentrations were correlated with raw THg concentrations observed in grebe blood $\left(R^{2}=0.61, n=353\right.$; fig. 10 top panel), grebe eggs $\left(R^{2}=0.47, n=101\right.$; fig. 10 bottom panel $)$, and sport fish $\left(R^{2}=0.83, n=230\right.$; fig. 10 middle panel), Generally, the model performed better at intermediate THg concentrations (sport fish: 0.1-7.0 $\mu \mathrm{g} / \mathrm{g} \mathrm{dw}$; grebe blood: $0.1-3.0 \mu \mathrm{g} / \mathrm{g} w \mathrm{w}$; grebe eggs: $0.04-0.2 \mu \mathrm{g} / \mathrm{g}$ fww) and poorer at very low or high $\mathrm{THg}$ concentrations where model-averaging tended to predict $\mathrm{THg}$ concentrations closer to the mean. This tendency for predictions to regress toward the mean indicates that individuals with very high $\mathrm{THg}$ concentrations will be underestimated, and individuals with very low $\mathrm{THg}$ concentrations will be overestimated. However, because we are using mean THg concentrations in prey fish at each lake rather than individuals to estimate risk to birds and sports fish, these errors will likely be minor.

\section{Management Application-Predictive Tool for Resource Managers}

Using the equations developed above, we built a predictive tool for use by natural resource managers (see Excel file entitled "USGS Wildlife and Sport Fish Risk Estimator Tool Final.xlsx" available at http://www.werc.usgs.gov/mercuryriskinlakes). Users can follow the guidelines in the tool's worksheet entitled "Tutorial." Tool users will need to enter THg concentrations in prey fish, date sampled, and the specific lake's attributes, and our tool will then predict THg concentrations in grebe blood, grebe eggs, and sport fish. Furthermore, our tool uses these estimated values to assess the relative risk to the animal by comparing the estimated $\mathrm{THg}$ concentrations to published toxicity benchmarks. Figure 11 illustrates the tool using $\mathrm{THg}$ concentrations in prey fish and physical attributes from Lake Berryessa as a high-Hg lake example. Figure 12 illustrates the tool using $\mathrm{THg}$ concentrations in prey fish and physical attributes from Big Lake as a low-Hg example.

The specific steps for using the tool are as follows.

1. First, the user would enter THg concentrations in prey fish at the lake of interest in microgram per gram dry weight. We suggest determining THg concentrations in prey fish on a whole-body and dry-weight basis, but entering values on a wet-weight basis and also entering moisture content is acceptable.

2. Second, the user enters the date the prey fish were sampled, as the number of days since January 1 of each year.

3. Third, the user would enter the specific lake's attributes, including lake area in hectares, lake perimeter in kilometers, and the lake's elevation in meters. These lake variables are available in the tool's worksheet entitled "Lake Attribute Data." We have included lake attribute data for 4,316 lakes in California; if lake data are not included in the worksheet, the user will need to obtain those data independently. The tool will calculate the lake's shape index from the lake area and perimeter data.

4. Fourth, the user would enter the desired total length in millimeters for the sport fish $\mathrm{THg}$ estimate. The specific values entered should fall within the general range of the fish and lake data used to generate the model (table 11), and these metadata are included in the tool's worksheet entitled "Appropriate Data Ranges." Additionally, we recommend that users only use the prediction for the sport fish species that inhabit the specific lake. 
The tool then estimates the THg concentrations in grebe blood (including an average grebe, or by species and sex), grebe eggs (combining grebe species and type of eggs), and sport fish (by species), and assesses the relative risk of mercury to wildlife and sport fish if they were to consume prey fish from the specific lake. Table 12 shows the toxicity benchmarks and associated citations used to generate the relative risk estimates.

For bird blood, toxicity benchmarks across multiple taxa, and grebes specifically, are still lacking. However, benchmarks for deleterious effects of $\mathrm{Hg}$ on reproduction have been developed for common loon (Gavia immer) blood (Evers and others, 2004): less than $1.0 \mu \mathrm{g} / \mathrm{g}$ ww is considered low risk, $1.0-3.0 \mu \mathrm{g} / \mathrm{g}$ ww is considered medium risk, $3.0-4.0 \mu \mathrm{g} / \mathrm{g}$ ww is considered high risk, and greater than $4.0 \mu \mathrm{g} / \mathrm{g}$ ww is considered extra-high risk. These values are similar to toxicity benchmarks derived by Depew and others (2012) for dietary MeHg exposure to common loons. Depew and others (2012) derived three benchmarks - $0.1 \mu \mathrm{g} / \mathrm{g}$ ww in prey fish is the threshold for adverse behavioral impacts in adult loons, $0.18 \mu \mathrm{g} / \mathrm{g}$ ww in prey fish corresponds to significant reproductive impairment in loons, and $0.4 \mu \mathrm{g} / \mathrm{g}$ ww in prey fish corresponds to complete reproductive failure in loons. For example, Burgess and Meyer (2008) found that maximum loon productivity was reduced by 50 percent when $\mathrm{THg}$ concentrations were $4.3 \mu \mathrm{g} / \mathrm{g}$ ww in loon blood and $0.21 \mu \mathrm{g} / \mathrm{g}$ ww in prey fish. Using Burgess and Meyer's (2008) equation, maximum loon productivity would be reduced by approximately 13, 36, and 47 percent when THg concentrations in loon blood were at the 1.0,3.0, and $4.0 \mu \mathrm{g} / \mathrm{g}$ ww risk benchmarks we used in this study.

Sensitivity of avian embryos to $\mathrm{Hg}$ can differ widely among species (Heinz and others, 2009). For example, Heinz and others (2009) classified 26 bird species according to their sensitivity to $\mathrm{Hg}$ toxicity and found that species that were highly sensitive to $\mathrm{Hg}$ toxicity had median lethal concentrations $\left(\mathrm{LC}_{50}\right)$ at less than $0.25 \mu \mathrm{g} / \mathrm{g}$ ww of injected $\mathrm{Hg}$. However, $\mathrm{MeHg}$ injected directly into eggs is more toxic than maternally deposited MeHg (Heinz and others, 2009), thus it is unclear how an $\mathrm{LC}_{50}$ estimated from egg-injection studies relates to potential toxicity in the wild. Egg THg concentrations greater than $0.50 \mu \mathrm{g} / \mathrm{g}$ fww have long been considered a concentration at which bird reproduction can be impaired (review by Wiener and others, 2003). Lastly, we chose $0.65 \mu \mathrm{g} / \mathrm{g}$ fww as an exposure concentration at which birds are at extra-high risk of reproductive impairment, because multiple studies have documented effects near this value. For example, we estimated a sublethal threshold of $8.51 \mu \mathrm{g} / \mathrm{g} \mathrm{dw}$ in liver, where waterbirds begin to demethylate the toxic form of $\mathrm{Hg}(\mathrm{MeHg})$ into inorganic $\mathrm{Hg}$ for four species breeding in California (Eagles-Smith and others, 2009; Ackerman and others, 2014). This liver THg threshold of $8.51 \mu \mathrm{g} / \mathrm{g} \mathrm{dw}$ corresponds to an egg THg concentration of $0.65 \mu \mathrm{g} / \mathrm{g}$ fww (Ackerman and others, 2014). Based on the preceding, we used the following $\mathrm{Hg}$ toxicity benchmarks for identifying risk of impaired reproduction to grebe eggs-less than $0.25 \mu \mathrm{g} / \mathrm{g}$ fww was considered low risk, $0.25-0.50 \mu \mathrm{g} / \mathrm{g}$ fww was considered medium risk, $0.50-0.65 \mu \mathrm{g} / \mathrm{g}$ fww was considered high risk, and greater than $0.65 \mu \mathrm{g} / \mathrm{g}$ fww was considered extra-high risk of impaired reproduction.

For sport fish, we used a no-observed-effects-residue (NOER) of $0.20 \mu \mathrm{g} / \mathrm{g}$ ww (Beckvar and others, 2005) and a lowest-observed-effects-residue (LOER) of $0.30 \mu \mathrm{g} / \mathrm{g}$ ww (Sandheinrich and others, 2011). The NOER threshold identifies the Hg concentration in fish tissues below which fish should not experience deleterious effects of $\mathrm{Hg}$ exposure on reproduction, growth, or survival. In contrast, the LOER threshold indicates the $\mathrm{Hg}$ concentration above which sublethal endpoints of $\mathrm{Hg}$ exposure, including alterations to reproductive health, have been documented in laboratory and field studies of freshwater fish. We therefore used the following $\mathrm{Hg}$ toxicity benchmarks for identifying risk to sport fish-less than $0.20 \mu \mathrm{g} / \mathrm{g}$ ww was considered low risk, $0.20-0.30 \mu \mathrm{g} / \mathrm{g}$ ww was considered medium risk, $0.30-0.40 \mu \mathrm{g} / \mathrm{g}$ ww was considered high risk, and greater than $0.40 \mu \mathrm{g} / \mathrm{g}$ ww was considered extra-high risk. 


\section{Mercury Correlations between Grebe Blood, Grebe Eggs, and Sport Fish}

Although the goal of this study was to use $\mathrm{THg}$ concentrations in prey fish to estimate $\mathrm{THg}$ concentrations in predators (grebe blood, grebe eggs, and sport fish), it is informative to know how well $\mathrm{THg}$ concentrations in grebe blood, grebe eggs, and sport fish were related. Examination of least squares mean THg concentrations indicated that grebe blood was related to sport fish $\left(n=24\right.$ lakes, $R^{2}=0.59$, $F_{1,22}=31.79, p<0.0001$; fig. 13 top panel), grebe eggs were related to sport fish $\left(n=6\right.$ lakes, $R^{2}=0.67$, $F_{1,4}=8.17, p=0.05$; fig. 13 middle panel), and grebe eggs were strongly related to grebe blood $(n=7$ lakes, $R^{2}=0.93, F_{1,5}=71.43, p<0.001$; fig. 13 bottom panel).

Equations for these relationships are as follows:

$$
\begin{gathered}
\ln \left(\text { Blood } \overline{T H g}_{\text {grebe } ; \frac{\mu g}{g} w w}\right)=0.03+0.966\left(\ln \left(\overline{T H g}_{\text {sportfish } ; \frac{\mu g}{g} d w}\right)\right) \\
\ln \left(E g g \overline{T H g}_{\text {grebe } ; \frac{\mu g}{g} f w w}\right)=-1.97+0.720\left(\ln \left(\overline{T H g}_{\text {sportfish } ; \frac{\mu g}{g} d w} d\right)\right) \\
\ln \left(E g g \overline{T H g}_{\text {grebe } ; \frac{\mu g}{g} f w w}\right)=-1.94+0.883(\ln (\text { BloodTHg } \\
\text { grebe } \left.\left.; \frac{\mu g}{g} w w\right)\right)
\end{gathered}
$$

\section{Conclusions and Management Implications}

In this study, we specifically addressed three main management questions with broad applicability throughout the State.

\section{(1) Does methylmercury pose significant risks to aquatic life in a representative sample of California lakes and reservoirs?}

Overall, $\mathrm{Hg}$ exceeded $1.0 \mu \mathrm{g} / \mathrm{g}$ ww in blood in 28 percent of grebes, a blood-Hg level that generally puts birds at elevated risk of potential impairment (table 1). In particular, THg concentrations exceeded $1.0 \mu \mathrm{g} / \mathrm{g}$ ww in blood in more than 40 percent of all grebes sampled in 9 of the 25 lakes; these included Lake Berryessa, Topaz Lake, Crowley Lake, Lake Hennessey, Bridgeport Reservoir, East Park Reservoir, Lake Mendocino, Lake San Antonio, and Lake Casitas. This study did not specifically focus on the potential effects of these high $\mathrm{Hg}$ concentrations on grebes. However, elsewhere, we estimated a sublethal threshold of $8.51 \mu \mathrm{g} / \mathrm{g} \mathrm{dw}$ in liver (equivalent to $1.3 \mu \mathrm{g} / \mathrm{g}$ ww in blood) where waterbirds begin to demethylate the toxic form of $\mathrm{Hg}(\mathrm{MeHg})$ into inorganic $\mathrm{Hg}$ for four species breeding in California (Eagles-Smith and others, 2009; Ackerman and others, 2014). No eggs exceeded $0.5 \mu \mathrm{g} / \mathrm{g}$ fww at the seven lakes where they were sampled. However, eggs were sampled from lakes that were at the low end of the observed $\mathrm{THg}$ concentrations in grebe blood and fish among all lakes in this study (fig. 3). Thus, the potential exists for $\mathrm{Hg}$ impairment of grebes and other piscivorous wildlife in many California lakes. 
$\mathrm{Hg}$ concentrations in sport fish also were elevated; Hg concentrations exceeded $0.30 \mu \mathrm{g} / \mathrm{g}$ ww in 48 percent of sport fish where sublethal endpoints of $\mathrm{Hg}$ exposure have been documented in laboratory and field studies of fish (Sandheinrich and others, 2011). Hg concentrations exceeded $0.30 \mu \mathrm{g} / \mathrm{g} \mathrm{ww}$ in at least 1 sportfish in 18 of the 24 lakes sampled. Furthermore, $\mathrm{THg}$ concentrations exceeded $0.30 \mu \mathrm{g} / \mathrm{g}$ ww in more than 50 percent of all sport fish sampled in 13 of the 24 lakes; these included Black Butte Reservoir, Clear Lake, Lake Berryessa, Lake Casitas, Lake Hennessey, Lake Mendocino, Lake Success, Lake Cuchuma, Thermalito Afterbay, Lake San Antonio, East Park Reservoir, Crowley Lake, and Topaz Lake. A more comprehensive study specifically monitoring Hg concentrations in sport fish sampled from 250 California lakes is available in Davis and others (2010).

\section{(2) Can a correlational approach be applied on a statewide basis to estimate risks to birds?}

We found strong relationships between $\mathrm{Hg}$ concentrations in piscivorous wildlife (represented by western grebes and Clark's grebes) and prey fish among California lakes. Similarly, $\mathrm{Hg}$ concentrations in prey fish were a strong predictor of $\mathrm{Hg}$ concentrations in sport fish. Using a modelaveraging approach, we were able to develop equations to predict $\mathrm{Hg}$ concentrations in bird blood, bird eggs, and sport fish using $\mathrm{Hg}$ concentrations in prey fish, sampling date, and lake attributes. We then applied these equations to develop a tool for natural resource managers and regulators to use for predicting lake-specific risk of $\mathrm{Hg}$ to wildlife and sport fish. This tool, which can be downloaded for use at: http://www.werc.usgs.gov/mercuryriskinlakes, can be effectively used to estimate $\mathrm{Hg}$ risk to piscivorous wildlife on a statewide basis among California lakes and reservoirs, within the applicable data ranges of this study. These appropriate data ranges for our model's application are available in the tool's worksheet entitled "Appropriate Data Ranges." Because we specifically designed our study to cover a broad range of lake elevations, sizes, and shapes and $\mathrm{Hg}$ exposure levels throughout the State, our tool is fairly robust to the different environmental conditions common to California. However, it is important to note that this tool is directly applicable only to western grebes and Clark's grebes, and should be used with caution if predicting risk to other piscivorous bird species. Differences among wildlife species, such as prey selection and bioenergetics, likely would result in different $\mathrm{MeHg}$ biomagnification rates, and additional study would be needed to appropriately estimate $\mathrm{Hg}$ concentrations in other wildlife taxa. A few other studies have found correlations between $\mathrm{THg}$ concentrations in bird blood and THg concentrations in prey fish, particularly for common loons breeding on lakes in the northeast (Scheuhammer and others, 1998; Champoux and others, 2006; Burgess and Meyer, 2008; Yu and others, 2011; Hosseini and others, 2013).

We also provided equations to predict $\mathrm{THg}$ concentrations in grebe blood from $\mathrm{THg}$ concentrations in sport fish for occasions when sport fish data are the only data available at a particular lake. However, the equations to predict $\mathrm{THg}$ concentrations in grebe blood using $\mathrm{THg}$ concentrations in prey fish are more robust than those using sport fish, and the prey fish models should be used when possible.

\section{(3) What are appropriate water-quality monitoring requirements to address methylmercury exposure in wildlife?}

We found that risk to piscivorous wildlife can be effectively estimated using $\mathrm{THg}$ concentrations in prey fish and associated lake and sampling date variables. However, the modeling and associated tool has its limitations. Whereas we used Aechmophorus grebes as our index of risk to piscivorous wildlife, species differences in $\mathrm{Hg}$ exposure, as well as pronounced differences in sensitivity to $\mathrm{Hg}$ among species (Heinz and others, 2009), should be considered when using such a generalized tool. Other species of wildlife that use California lakes, such as osprey, mergansers, kingfisher, and occasionally terns, might have even higher (or lower) Hg concentrations. For example, using Lake Berryessa data, 
we estimated that THg concentrations could differ from $3.08 \mu \mathrm{g} / \mathrm{g}$ ww for female western grebes to 4.76 $\mu \mathrm{g} / \mathrm{g}$ ww for male Clark's grebes. Such differences in Hg concentrations between species and sexes are real, and are further influenced by other bird-specific variables such as body condition, sampling date, and molt status. Because these bird-specific values are often unknown without direct sampling, we used mean values in our predictive models and in the tool's development. Therefore, while this tool can be highly useful to estimate levels of risk, there is still no substitute for direct sampling of birds and other wildlife for more precise estimates of $\mathrm{Hg}$ exposure.

Furthermore, least squares mean THg concentrations in prey fish were substantially better than geometric mean $\mathrm{THg}$ concentrations in prey fish at predicting $\mathrm{THg}$ concentrations in grebe blood, grebe eggs, and sport fish. The least squares mean THg concentrations in prey fish statistically accounted for inherent sampling biases in prey fish - namely, in variations in fish length and species of prey fish that were captured across sampling locations. Therefore, whereas entering geometric mean $\mathrm{THg}$ concentrations in prey fish into the model might be acceptable when only a single or very few lakes are sampled, standardizing the prey fish $\mathrm{THg}$ concentrations for length and species when a number of lakes are sampled is desirable. This can be done following the methods we describe in section, "Statistical Methods-Mercury by Lake."

We recommend sampling at least 20 prey fish individuals from 2 species from each lake and analyzing $\mathrm{THg}$ concentrations on an individual, rather than a composite, basis. Prey fish should be sampled during the breeding season (approximately April-July) when wildlife are at greatest risk to potential Hg-induced impairment, and sampling date should be standardized for annual monitoring programs because seasonal variation in prey fish $\mathrm{Hg}$ concentrations can be substantial (Eagles-Smith and Ackerman, 2009). Furthermore, this study is specific to lakes and should not be extrapolated to other water bodies such as wetlands; in wetland habitats, $\mathrm{THg}$ concentrations in prey fish may not be correlated to THg concentrations in piscivorous birds (Ackerman and others, 2014).

The California State Water Resources Control Board staff may propose a target value for $\mathrm{THg}$ concentrations in sport fish in California lakes of $0.2 \mu \mathrm{g} / \mathrm{g}$ ww to be protective of sport fish and wildlife (A. Palumbo, written commun., 2015). Using the equation developed in this study and the average moisture content of sport fish, a THg concentration of $0.2 \mu \mathrm{g} / \mathrm{g} \mathrm{ww}(0.92 \mu \mathrm{g} / \mathrm{g} \mathrm{dw})$ in sport fish corresponds to a $\mathrm{THg}$ concentration of $1.0 \mu \mathrm{g} / \mathrm{g} \mathrm{ww}$ in grebe blood. Alternatively, if the California State Water Resources Control Board wanted to use a target value for THg concentrations in prey fish, instead of sport fish, than a $\mathrm{THg}$ concentration of $0.05 \mu \mathrm{g} / \mathrm{g}$ ww in prey fish corresponds to a $\mathrm{THg}$ concentration of $1.0 \mu \mathrm{g} / \mathrm{g}$ ww in grebe blood (using average values for prey fish moisture content and lake variables). As discussed previously, $1.0 \mu \mathrm{g} / \mathrm{g}$ ww in bird blood corresponds to the beginning of the "moderate risk" benchmark for potential impaired reproduction in birds. These values represent average $\mathrm{THg}$ concentrations in grebes within a lake, and therefore approximately one-half of the individual grebes would have THg concentrations greater than this "moderate risk" toxicity benchmark, and onehalf would have less than this moderate risk toxicity benchmark. Thus, if the THg concentration of 0.2 $\mu \mathrm{g} / \mathrm{g}$ ww in sport fish is meant to be protective for all individual grebes, and potentially other wildlife, the California State Water Resources Control Board could consider lowering this target value. 


\section{References Cited}

Ackerman, J.T., and Eagles-Smith, C.A., 2010, Accuracy of egg flotation throughout incubation to determine embryo age and incubation day in waterbird nests: Condor, v. 112, no. 3, p. 438-446.

Ackerman, J.T., Eagles-Smith, C.A., Heinz, G.H., De La Cruz, S.E., Takekawa, J.Y., Miles, A.K., Adelsbach, T.L., Herzog, M.P., Bluso-Demers, J.D., Demers, S.A., Herring, G., Hoffman, D.J., Hartman, C.A., Willacker, J.J., Suchanek, T.H., Schwarzbach, S.E., and Maurer, T.C.,, 2014, Mercury in birds of San Francisco Bay-Delta, California-Trophic pathways, bioaccumulation, and ecotoxicological risk to avian reproduction: U.S. Geological Survey Open-File Report 2014-1251, $202 \mathrm{p}$.

Ackerman, J.T., Herzog, M.P., and Schwarzbach, S.E., 2013, Methylmercury is the predominant form of mercury in bird eggs-A synthesis: Environmental Science and Technology, v. 47, p. 2,052-2,060.

Arnold, T.W., 2010, Uninformative parameters and model selection using Akaike's information criterion: Journal of Wildlife Management, v. 74, no. 6, p. 1,175-1,178.

Beckvar, N., Dillon, T.M., and Read, L.B., 2005, Approaches for linking whole-body fish tissue residues of mercury or DDT to biological effects thresholds: Environmental Toxicology and Chemistry, v. 24, no. 8, p. 2,094-2,105.

Burgess, N.M., and Meyer, M.W., 2008, Methylmercury exposure associated with reduced productivity in common loons: Ecotoxicology, v. 17, no. 2, p. 83-91.

Burnham, K.P., and Anderson, D.R., 2002, Model selection and multimodel inference-A practical information-theoretic approach (2nd ed.): New York, Springer-Verlag, 488 p...

Champoux, L., Masse, D.C., Evers, D., Lane, O.P., Plante, M., and Timmermans, S.T.A., 2006, Assessment of mercury exposure and potential effects on common loons (Gavia immer) in Québec: Hydrobiologia, v. 567, no. 1, p. 263-274.

Davis, J.A., Melwani, A.R., Bezalel, S.N., Hunt, J.A., Ichikawa, G., Bonnema, A., Heim, W.A., Crane, D., Swenson, S., Lamerdin, C., and others, 2010, Contaminants in fish from California lakes and reservoirs, 2007-2008 - Summary report on a two-year screening survey: Sacramento, California State Water Resources Control Board, A Report of the Surface Water Ambient Monitoring Program (SWAMP).

Davis, J.A., Ross, J.R.M., Bezalel, S.N., Melwani, A.R., Allen, R., Ichikawa, G., Bonnema, A., Heim, W., Crane, D., Swenson, S., and others, 2012, Contaminants in fish from the California coast, 20092010 - Summary report on a two-year screening survey: Sacramento, California State Water Resources Control Board, A Report of the Surface Water Ambient Monitoring Program (SWAMP).

Depew, D.C., Basu, N., Burgess, N.M., Campbell, L.M., Evers, D.C., Grasman, K.A., and Scheuhammer, A.M., 2012, Derivation of screening benchmarks for dietary methylmercury exposure for the common loon (Gavia immer) - Rationale for use in ecological risk assessment: Environmental Toxicology and Chemistry, v. 31, no. 10, p. 2,399-2,407.

Eagles-Smith, C.A., and Ackerman, J.T., 2009, Rapid changes in small fish mercury concentrations in estuarine wetlands-Implications for wildlife risk and monitoring programs: Environmental Science and Technology, v. 43, no. 22, p. 8,658-8,664.

Eagles-Smith, C.A., Ackerman, J.T., Yee, J., and Adelsbach, T.L., 2009, Mercury demethylation in waterbird livers-Dose-response thresholds and differences among species: Environmental Toxicology and Chemistry, v. 28, no. 3, p. 568-577.

Evers, D., Lane, O., Savoy, L., and Goodale, W., 2004, Assessing the impacts of methylmercury on piscivorous wildlife using a wildlife criterion value based on the Common Loon, 1998-2003: Gorham, Maine, BioDiversity Research Institute, Report BRI 2004-05 submitted to the Maine Department of Environmental Protection. 
Heinz, G.H., Hoffman, D.J., Klimstra, J.D., Stebbins, K.R., Kondrad, S.L., and Erwin, C.A., 2009, Species differences in the sensitivity of avian embryos to methylmercury: Archives of Environmental Contamination and Toxicology, v. 56, no. 1, p. 129-138.

Hosseini, M., Nabavi, S.M.B., and Parsa, Y., 2013, Bioaccumulation of trace mercury in trophic levels of benthic, benthopelagic, pelagic fish species, and sea birds from Arvand River, Iran: Biological trace element research, v. 156, no. 1-3, p. 175-80.

King, D.T., Andrews, K.J., King, J.O., Flynt, R.D., Glahn, J.F., and Cummings, J.L., 1994, A nightlighting technique for capturing cormorants: Journal of Field Ornithology, v. 65, no. 2, p. 254-257.

Lawrence, G., 1950, The diving and feeding activity of the Western Grebe on the breeding grounds: Condor, v. 52, no. 1, p. 3-16.

McGarigal, K., 2014, Fragstats Help: Amherst, University of Massachusetts, 182 p., http://www.umass.edu/landeco/research/fragstats/documents/fragstats.help.4.2.pdf.

Sandheinrich, M.B., Bhavsar, S.P., Bodaly, R.A., Drevnick, P.E., and Paul, E.A., 2011, Ecological risk of methylmercury to piscivorous fish of the Great Lakes region: Ecotoxicology, v. 20, no. 7, p. 1,5771,587 .

Scheuhammer, A.M., Atchison, C.M., Wong, A.H.K., and Evers, D.C., 1998, Mercury exposure in breeding common loons (Gavia immer) in Central Ontario, Canada: Environmental Toxicology and Chemistry, v. 17, no. 2, p. 191-196.

Seber, G.A.F., 1982, The estimation of animal abundance and related parameters (2nd ed.): New York, Macmillan, $672 \mathrm{p}$.

U.S. Environmental Protection Agency, 2000, Method 7473, Mercury in solids and solutions by thermal decomposition, amalgamation, and atomic absorption spectrophotometry, in Test methods for evaluating solid waste, physical/chemical methods: Washington, D.C., U.S. Government Printing Office, SW 846, Update IVA.

Whitworth, D., Takekawa, J., Carter, H., and McIver, W., 1997, A night-lighting technique for at-sea capture of Xantus' Murrelets: Colonial Waterbirds, v. 20, no. 3, p. 525-531.

Wiener, J.G., Krabbenhoft, D.P., Heinz, G.H., and Scheuhammer, A.M., 2003, Ecotoxicology of mercury, in Hoffman, D.J., Rattner, B.A., Burton, G.A.J., and Cairns, J.J., eds., Handbook of Ecotoxicology (2nd ed.): Boca Raton, Florida, CRC Press LCC, p. 409-463.

Yu, X., Driscoll, C.T., Montesdeoca, M., Evers, D., Duron, M., Williams, K., Schoch, N., and Kamman, N.C., 2011, Spatial patterns of mercury in biota of Adirondack, New York lakes: Ecotoxicology, v. 20, no. 7, p. 1,543-1,554. 


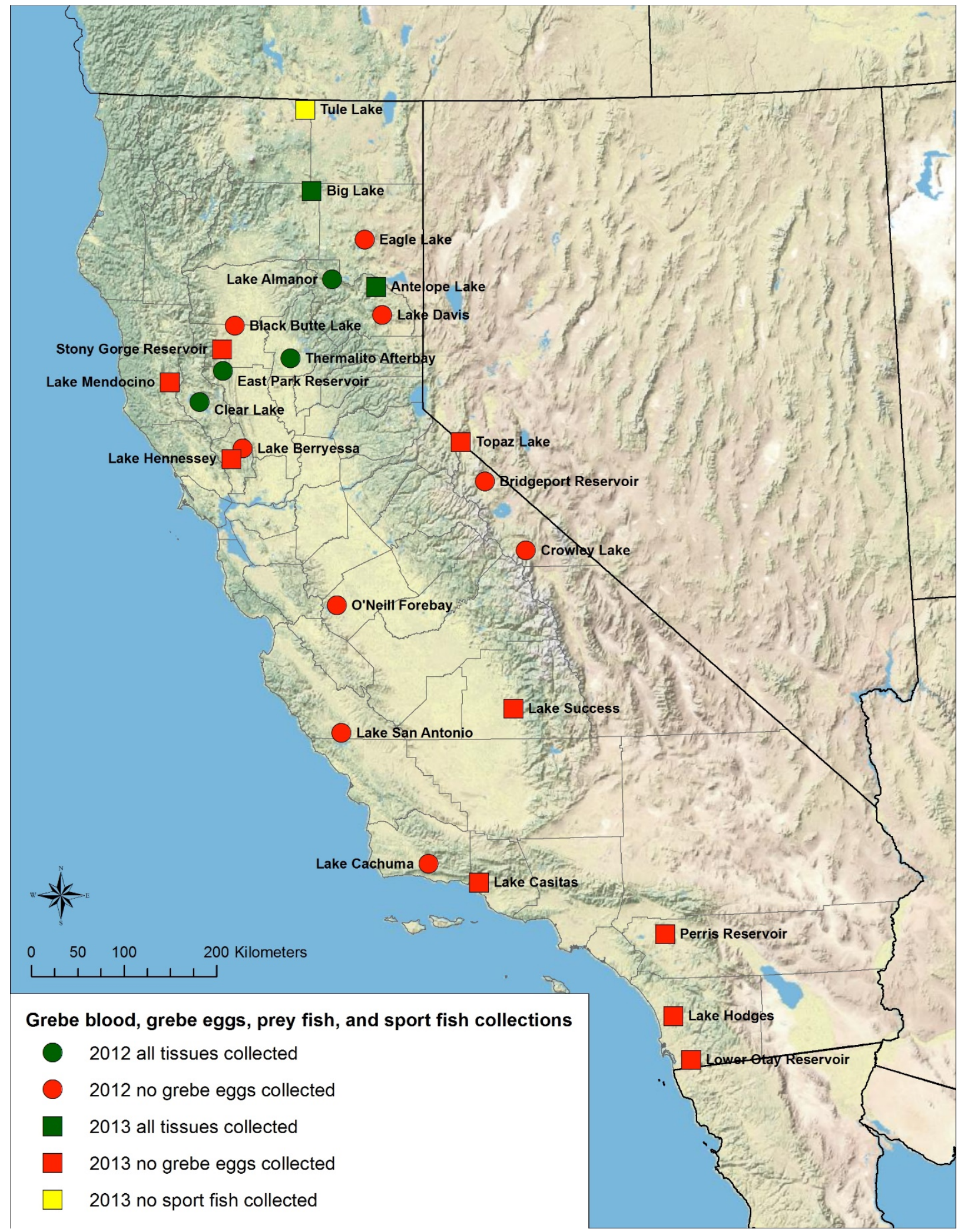

Figure 1. Map showing location of the 25 lakes and reservoirs where grebes, sport fish, and prey fish were collected for mercury analyses of blood, eggs, and tissue, California, 2012-13. Topography layer by U.S. National Park Service. 


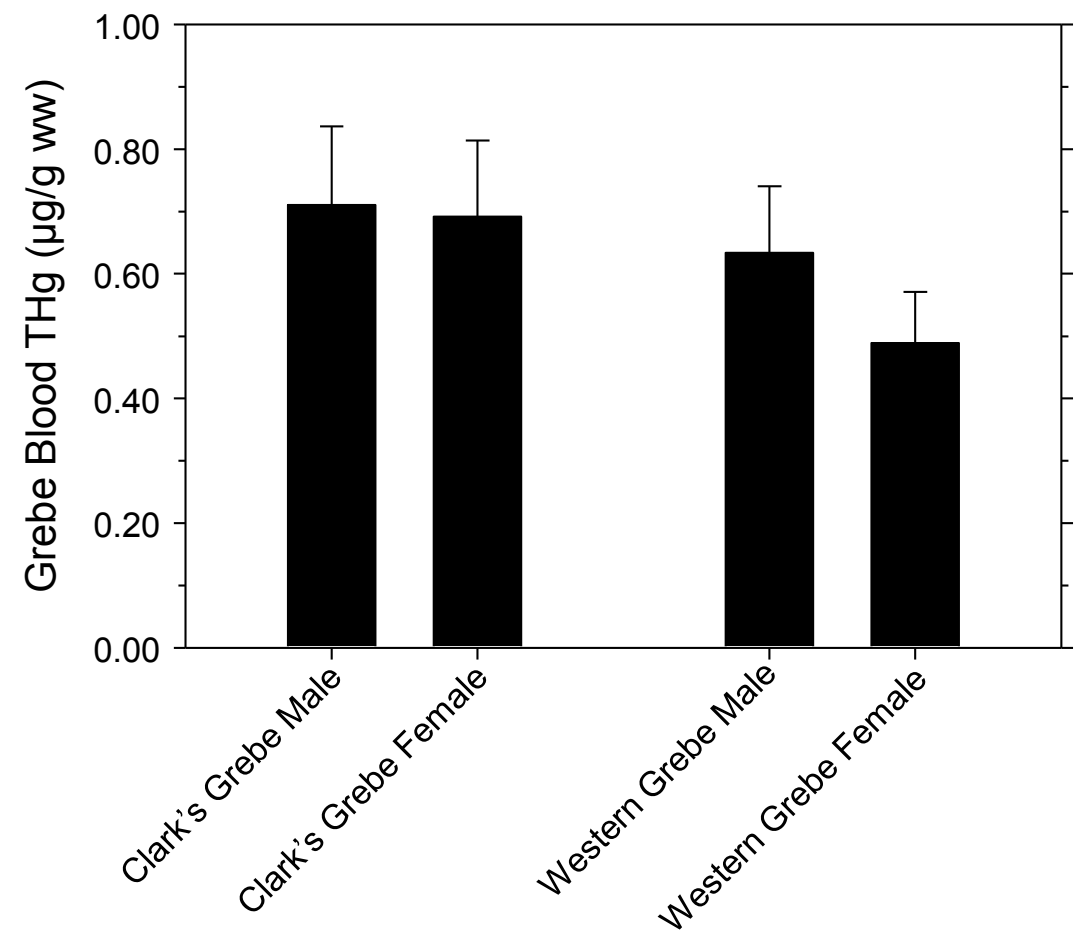

Figure 2. Graph showing total mercury (THg) concentrations (in micrograms per gram wet weight [ $\mu \mathrm{g} / \mathrm{g} \mathrm{ww}]$ ) in blood of male and female Clark's grebes and western grebes captured at 25 lakes in California, 2012-13. Values are least squares means \pm standard errors from a global model accounting for species and sex, with lake as a random effect. 

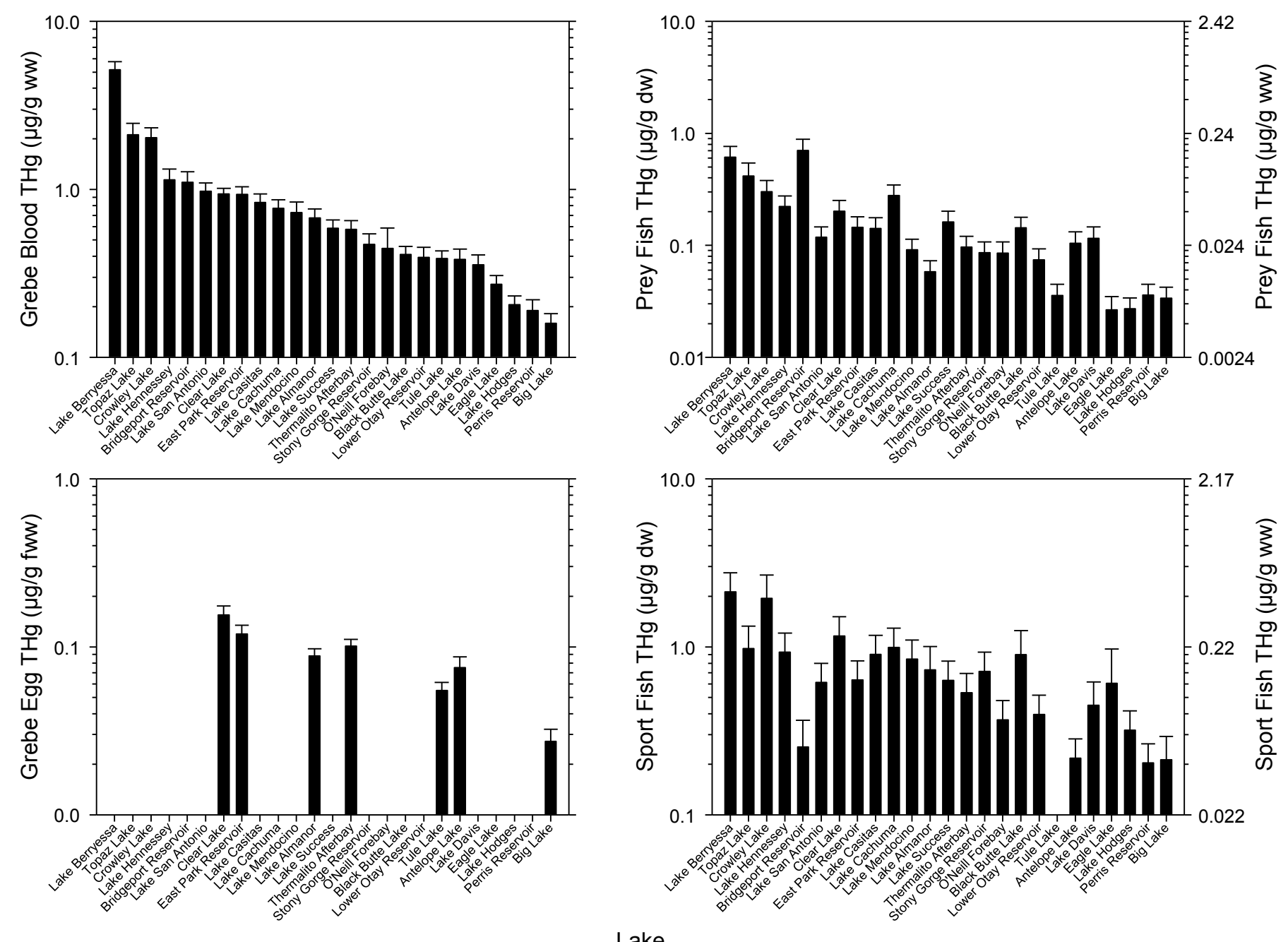

Figure 3. Graphs showing total mercury (THg) concentrations (in micrograms per gram dry weight [ $\mu \mathrm{g} / \mathrm{g} \mathrm{dw]} \mathrm{[left} Y$ axis]; or in $\mu \mathrm{g} / \mathrm{g}$ wet weight [ww] [right $Y$ axis]) in grebe blood (top left panel), prey fish (top right panel), grebe eggs (bottom left panel), and sport fish (bottom right panel) sampled at as many as 25 lakes in California, 2012-13. Values are least squares means \pm standard errors from separate models accounting for (1) grebe blood model: species and sex with lake as a random effect; (2) prey fish model-species, standard length, and species $\times$ length interaction with lake as a random effect; (3) grebe egg model—species and egg type with lake as a random effect; and (4) sport fish model—species, total length, and species $\times$ length interaction with lake as a random effect. 

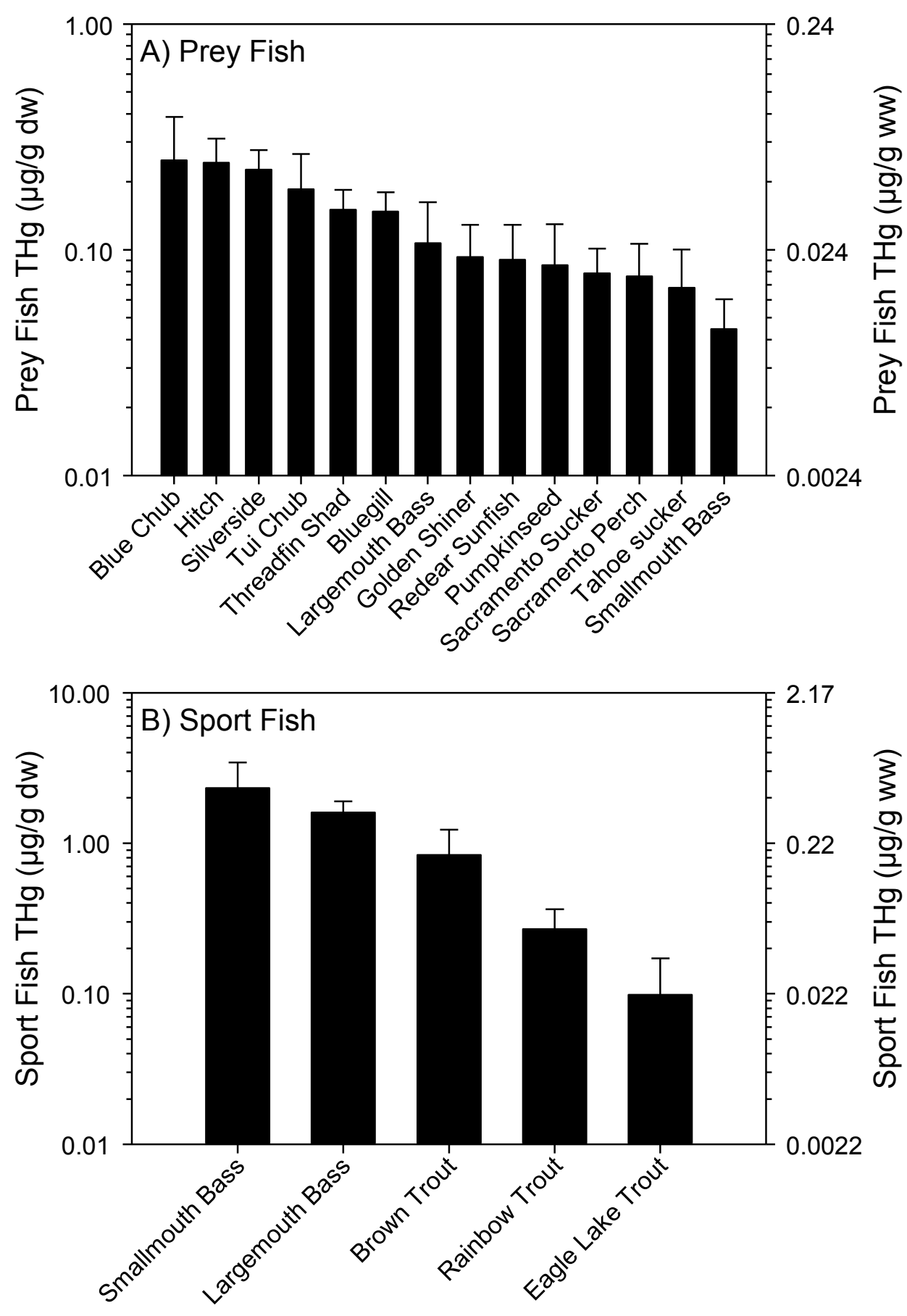

Figure 4. Graphs showing total mercury $(\mathrm{THg})$ concentrations (in micrograms per gram dry weight $[\mu \mathrm{g} / \mathrm{g} \mathrm{dw}][\mathrm{left} Y$ axis] or in $\mu \mathrm{g} / \mathrm{g}$ wet weight [ww] [right $\mathrm{Y}$ axis]) in (A) whole prey fish by species from 25 lakes and (B) sport fish fillets by species from 24 lakes in California, 2012-13. Values are least squares means \pm standard errors from separate models accounting for species, length, and species $\times$ length interaction with lake as a random effect. 

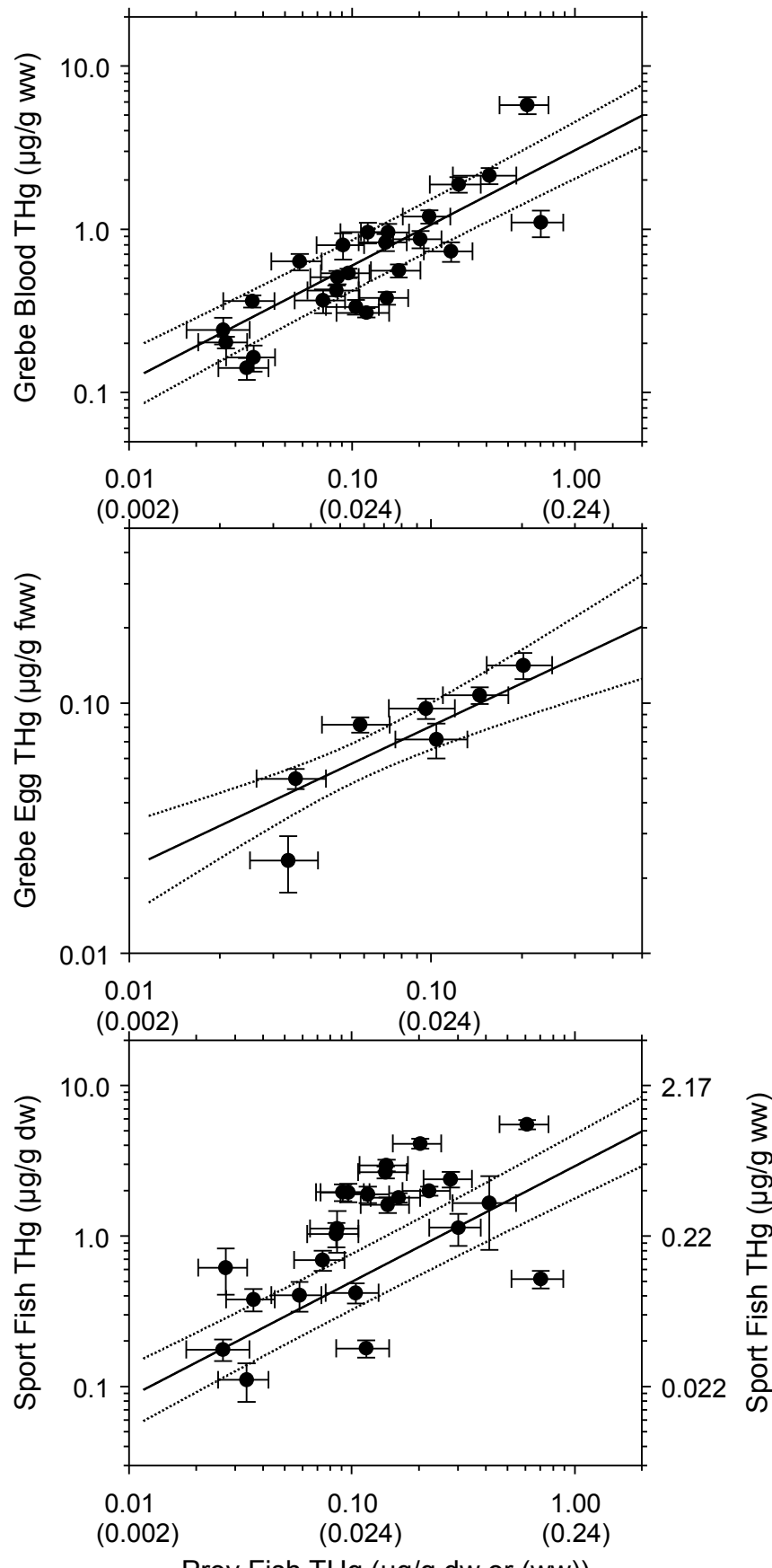

Prey Fish THg $(\mu \mathrm{g} / \mathrm{g} \mathrm{dw}$ or $(\mathrm{ww}))$

Figure 5. Graphs showing total mercury (THg) concentrations (in micrograms per gram dry weight [ $\mu \mathrm{g} / \mathrm{g} \mathrm{dw}][\mathrm{left} Y$ axis] or $\mu \mathrm{g} / \mathrm{g}$ wet weight [ww] [right $Y$ axis]) in grebe blood (top panel), grebe eggs (middle panel), and sport fish (bottom panel) versus THg concentrations in prey fish ( $\mu \mathrm{g} / \mathrm{g} \mathrm{dw}$ [top row $X$ axis] or $\mu \mathrm{g} / \mathrm{g}$ ww [bottom row $X$ axis]) sampled at up to 25 lakes in California, 2012-13. Y-axis values are geometric means \pm standard errors and $X$-axis values are least squares means \pm standard errors from a global model accounting for species, standard length, and species $\times$ length interaction with lake as a random effect. The solid line is the model-averaged predicted THg concentration and the stippled lines are the 95-percent confidence limits of the model-averaged predicted $\mathrm{THg}$ concentration. Model predictions were generated by setting all other variables in the predictive model to their mean values (or mode for wing molt and median for date), except for total length of sport fish, which was set to 350 millimeters. 

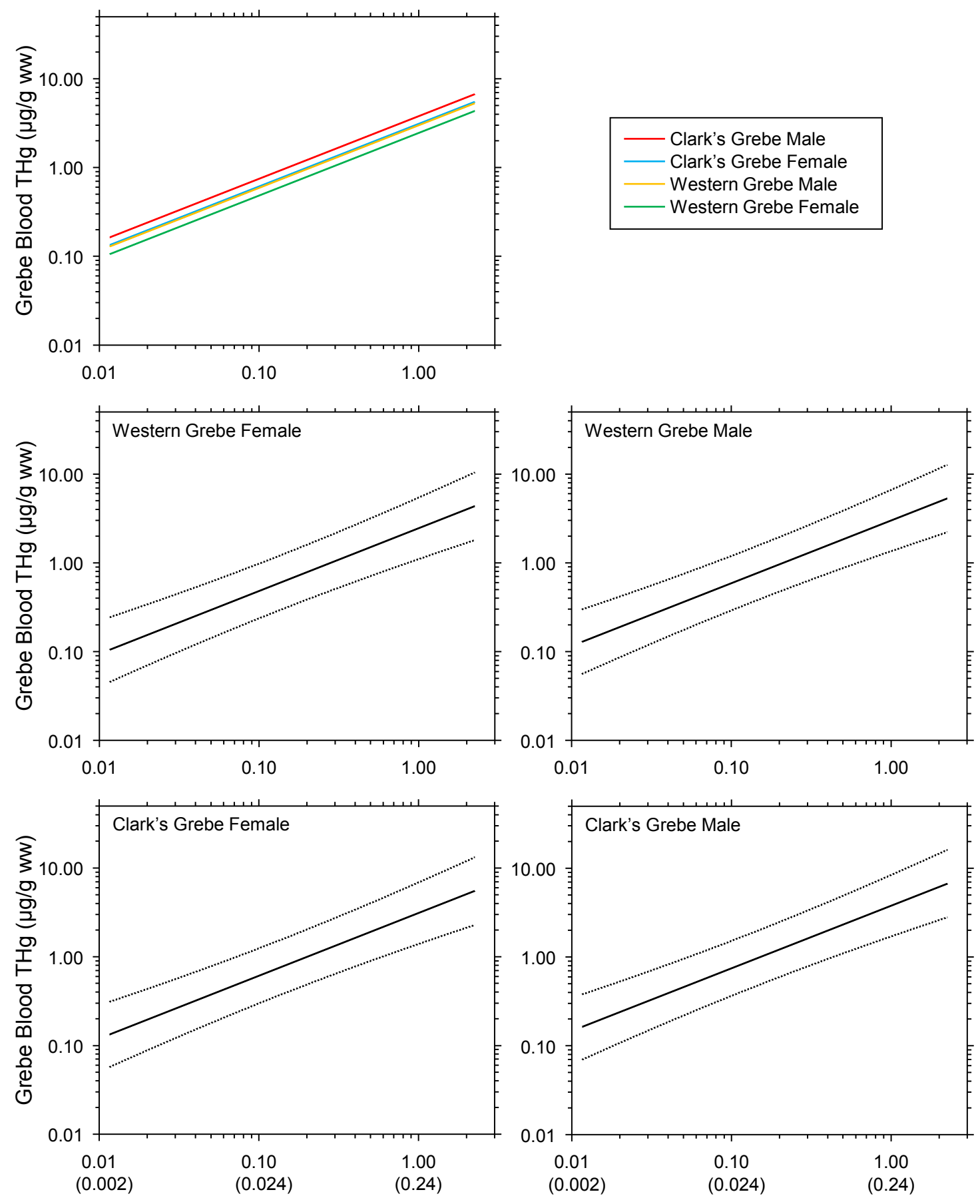

Prey Fish THg ( $\mu \mathrm{g} / \mathrm{g} \mathrm{dw}$ or $(w w))$

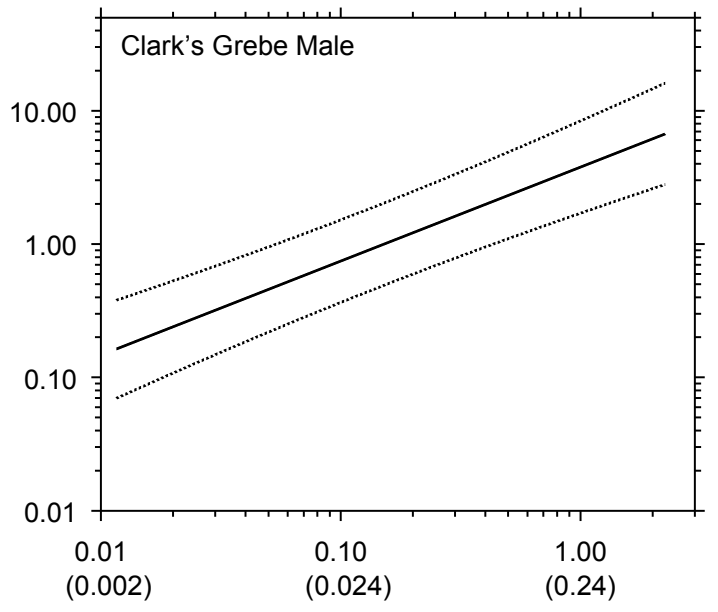

Prey Fish THg $(\mu \mathrm{g} / \mathrm{g} d w$ or $(w w))$

Figure 6. Graphs showing total mercury ( $\mathrm{THg}$ ) concentrations (in micrograms per gram wet weight $[\mu \mathrm{g} / \mathrm{g} w \mathrm{w}]$ ) in grebe blood by species and sex versus THg concentrations in prey fish ( $\mu \mathrm{g} / \mathrm{g}$ dry weight [dw] [top row $X$ axis] or in $\mu \mathrm{g} / \mathrm{g}$ ww [bottom row X axis]) sampled at 25 lakes in California, 2012-13. The solid lines are the model-averaged predicted THg concentration and the stippled lines are the 95-percent confidence limits of the model-averaged predicted THg concentration. The top left panel shows only the model-averaged mean predicted $\mathrm{THg}$ concentration for each species and sex, whereas the other panels shows species and sex-specific predictions with 95-percent confidence limits. Model predictions were generated by setting all other variables in the predictive model to their mean values (or mode for wing molt and median for date). 


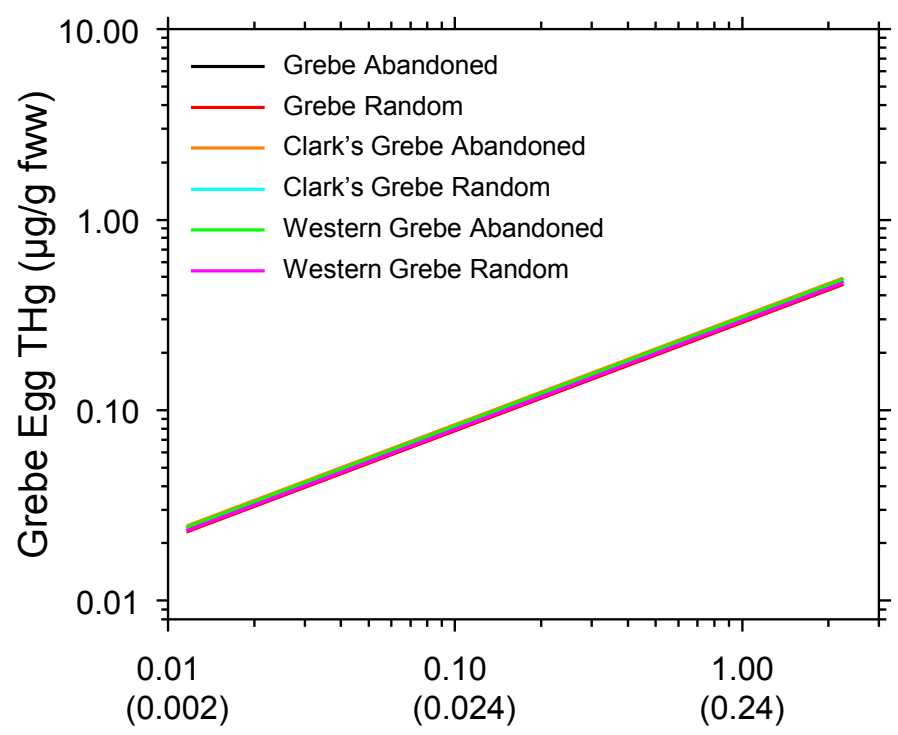

Prey Fish THg ( $\mu \mathrm{g} / \mathrm{g} \mathrm{dw}$ or $(\mathrm{ww}))$

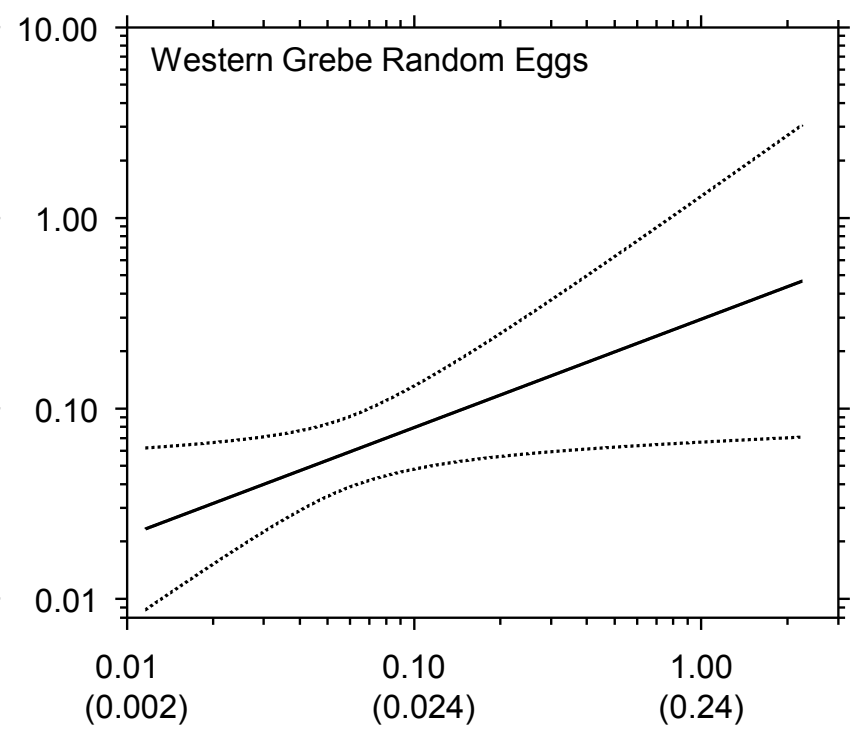

Prey Fish $\mathrm{THg}(\mu \mathrm{g} / \mathrm{g} \mathrm{dw}$ or $(\mathrm{ww}))$

Figure 7. Graphs showing total mercury (THg) concentrations (in micrograms per gram fresh water weight $[\mu \mathrm{g} / \mathrm{g}$ fww]) in grebe eggs by species and egg type (random or abandoned) versus THg concentrations in prey fish (in $\mu \mathrm{g} / \mathrm{g}$ dry weight [dw] [top row $X$ axis] or in $\mu \mathrm{g} / \mathrm{g}$ wet weight [ww] [bottom row $X$ axis]) sampled at seven lakes in California, 2012-13. The solid lines are the model-averaged predicted THg concentration and the stippled lines are the 95-percent confidence limits of the model-averaged predicted THg concentration. The left panel shows only the model-averaged mean predicted THg concentration for each species and egg type. The right panel shows the specific prediction with 95-percent confidence limits for randomly sampled western grebe eggs. Because there was no difference in the model-averaged predicted THg concentration among species and egg type, we show only one of the six possible combinations as an example to display the 95-percent confidence limits. Model predictions were generated by setting all other variables in the predictive model to their mean values (or median for date). 

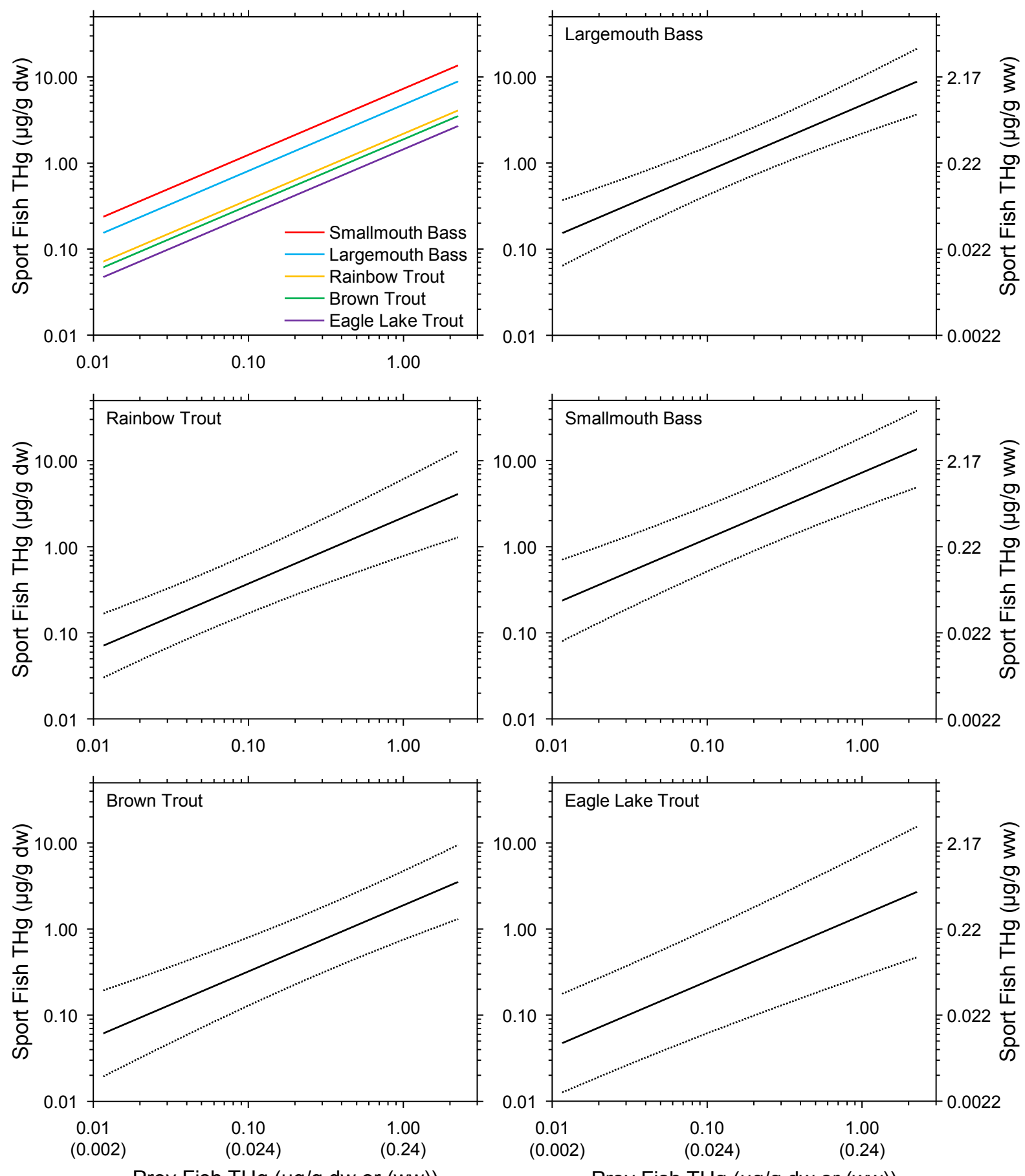

Figure 8. Graphs showing total mercury $(\mathrm{THg})$ concentrations (in micrograms per gram dry weight $[\mu \mathrm{g} / \mathrm{g} \mathrm{dw}][\mathrm{left}$ axis] or $\mu \mathrm{g} / \mathrm{g}$ wet weight [ww] [right $Y$ axis]) in sport fish by species versus THg concentrations in prey fish $(\mu \mathrm{g} / \mathrm{g} \mathrm{dw}$ [top row $X$ axis] or $\mu g / g$ ww [bottom row $X$ axis]) sampled at 24 lakes in California, 2012-13. The solid lines are the model-averaged predicted THg concentration and the stippled lines are the 95-percent confidence limits of the model-averaged predicted THg concentration. The top left panel shows only the model-averaged mean predicted $\mathrm{THg}$ concentration for each species, whereas the other panels shows species specific predictions with 95-percent confidence limits. Model predictions were generated by setting all other variables in the predictive model to their mean values (or median for date), except for total length of sport fish, which was set to 350 millimeters. 

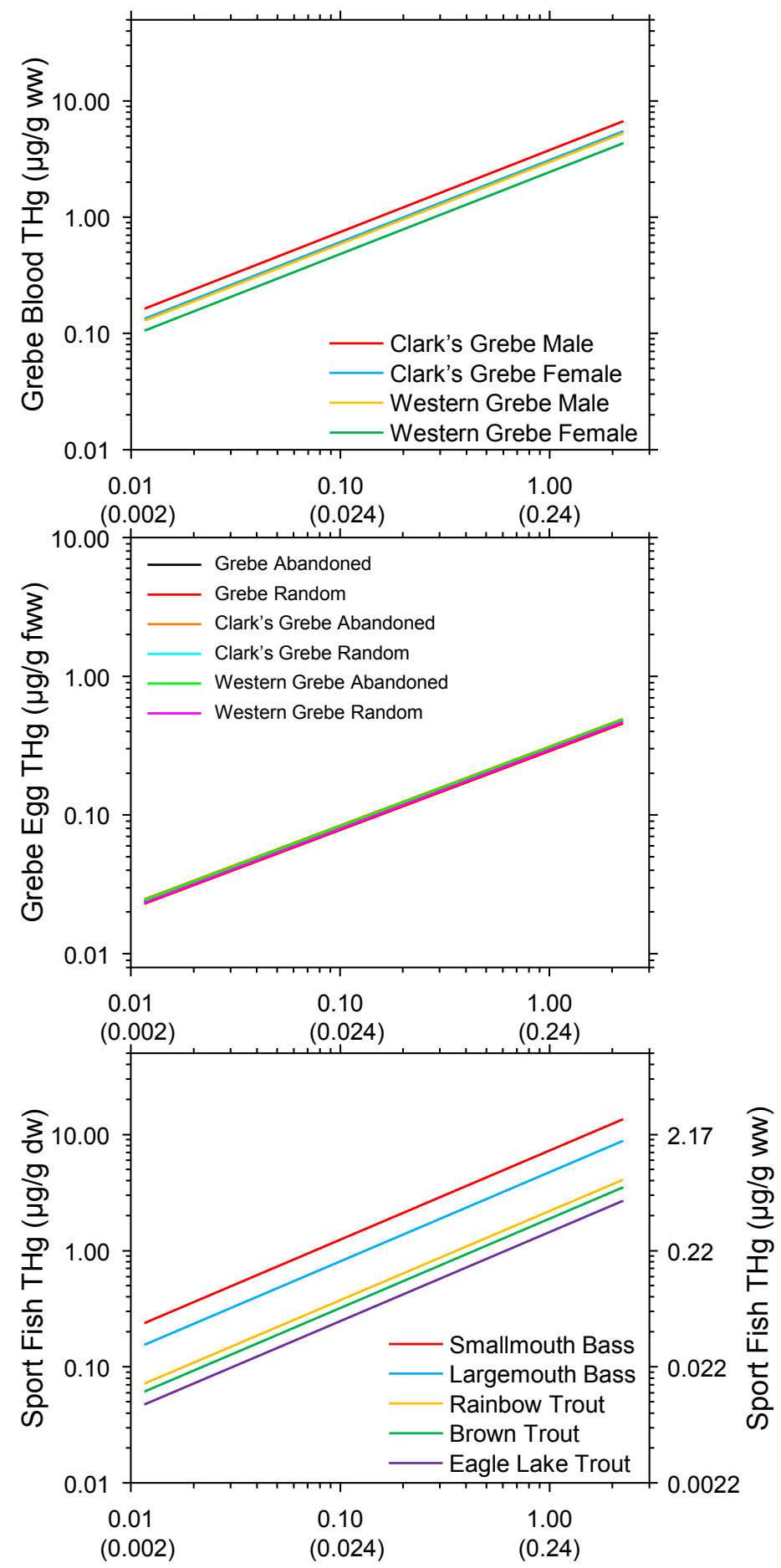

Prey Fish $\mathrm{THg}(\mu \mathrm{g} / \mathrm{g} \mathrm{dw}$ or $(\mathrm{ww}))$

Figure 9. Graphs showing total mercury $(\mathrm{THg})$ concentrations (in micrograms per gram dry weight [ $\mu \mathrm{g} / \mathrm{g} \mathrm{dw}][\mathrm{left} Y$ axis] or $\mu \mathrm{g} / \mathrm{g}$ wet weight [ww] [right $\mathrm{Y}$ axis]) in grebe blood (top panel), grebe eggs (middle panel), and sport fish (bottom panel) versus THg concentrations in prey fish ( $\mu \mathrm{g} / \mathrm{g} \mathrm{dw}$ [top row $X$ axis] or $\mu \mathrm{g} / \mathrm{g}$ ww [bottom row $X$ axis]) sampled at as many as 25 lakes in California, 2012-13. The solid lines are the model-averaged mean predicted THg concentration by species, sex, and/or egg type. Model predictions were generated by setting all other variables in the predictive model to their mean values (or mode for wing molt and median for date), except for total length of sport fish, which was set to 350 millimeters. 

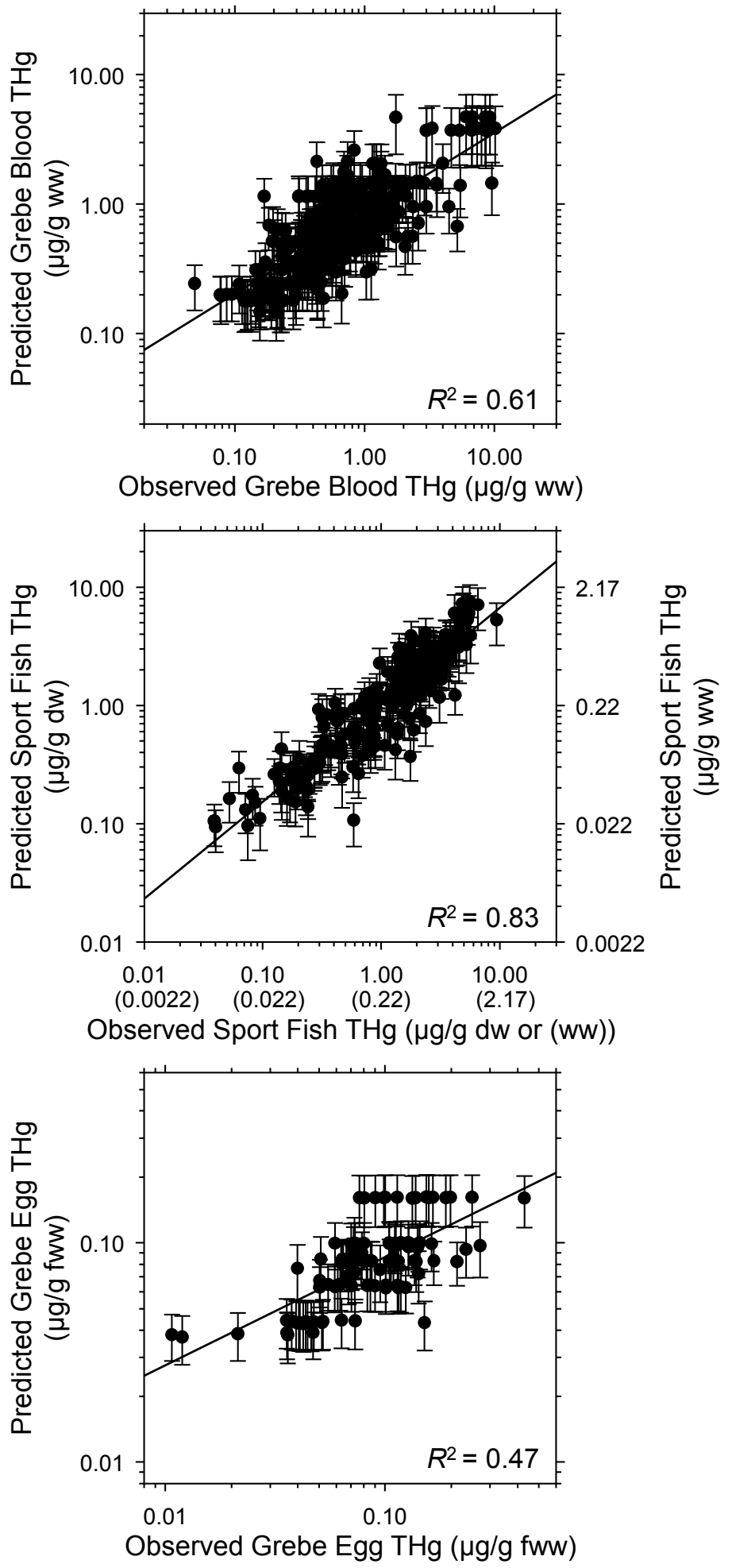

Figure 10. Graphs showing model-predicted mean \pm standard errors total mercury (THg) concentrations (in micrograms per gram dry weight [ $\mu \mathrm{g} / \mathrm{g} \mathrm{dw}$ ] [left $Y$ axis] or $\mu \mathrm{g} / \mathrm{g}$ wet weight [ww] [right $\mathrm{Y}$ axis]) versus observed (raw) $\mathrm{THg}$ concentrations ( $\mu \mathrm{g} / \mathrm{g} \mathrm{dw}$ [top row $X$ axis] or $\mu \mathrm{g} / \mathrm{g}$ ww [bottom row $X$ axis]) in grebe blood (top panel; $n=354$ ), sport fish (middle panel, $n=230$ ), and grebe eggs (bottom panel; $n=101$ ) in California, 2012-13. Model predictions were generated by using individual-specific data associated with the raw data point for all variables in the final model. 


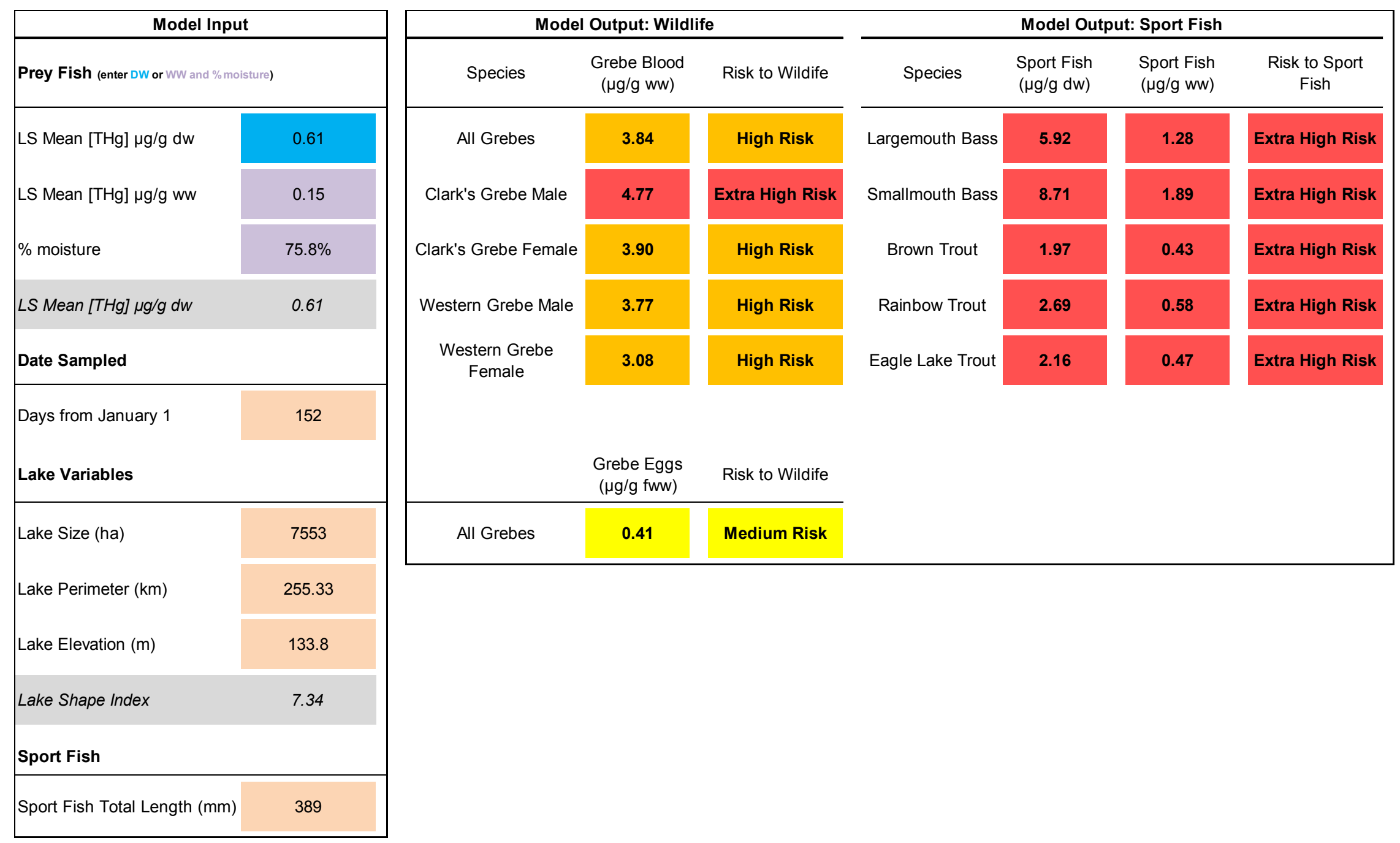

Figure 11. Example of our predictive tool for use by natural resource managers using Lake Berryessa specific data. Tool users will enter total mercury ( $\mathrm{THg}$ ) concentrations (in micrograms per gram dry weight $[\mu \mathrm{g} / \mathrm{g} \mathrm{dw}$ ) in prey fish, date sampled, and the specific lake's attributes (lake area, perimeter, and elevation), and our tool will estimate the predicted THg concentrations in grebe blood, grebe eggs, and sport fish. Our tool then uses these estimated values to assess the relative risk to wildlife and sport fish by comparing the estimated $\mathrm{THg}$ concentrations to published toxicity benchmarks. In this example, THg concentrations in prey fish at Lake Berryessa are very high, and thus the tool estimates that wildlife and sport fish are at high risk of potential mercury impairment. 


\begin{tabular}{|c|c|}
\hline \multicolumn{2}{|l|}{ Model Input } \\
\hline \multicolumn{2}{|c|}{ Prey Fish (enter DW or WW and \% moisture) } \\
\hline LS Mean [THg] $\mu g / g d w$ & 0.03 \\
\hline LS Mean $[\mathrm{THg}] \mu \mathrm{g} / \mathrm{g} w w$ & \\
\hline$\%$ moisture & \\
\hline LS Mean [THg] $\mu g / g d w$ & 0.03 \\
\hline Date Sampled & \\
\hline Days from January 1 & 204 \\
\hline Lake Variables & \\
\hline Lake Size (ha) & 703 \\
\hline Lake Perimeter (km) & 36.67 \\
\hline Lake Elevation (m) & 1007.4 \\
\hline Lake Shape Index & 3.46 \\
\hline Sport Fish & \\
\hline Sport Fish Total Length (mm) & 430 \\
\hline
\end{tabular}

\begin{tabular}{|c|c|c|c|c|c|c|}
\hline \multicolumn{3}{|c|}{ Model Output: Wildlife } & \multicolumn{4}{|c|}{ Model Output: Sport Fish } \\
\hline Species & $\begin{array}{c}\text { Grebe Blood } \\
(\mu \mathrm{g} / \mathrm{g} \mathrm{ww})\end{array}$ & Risk to Wildife & Species & $\begin{array}{l}\text { Sport Fish } \\
(\mu g / g d w)\end{array}$ & $\begin{array}{l}\text { Sport Fish } \\
(\mu g / g \text { ww) }\end{array}$ & $\begin{array}{l}\text { Risk to Sport } \\
\text { Fish }\end{array}$ \\
\hline All Grebes & 0.23 & Low Risk & Largemouth Bass & 0.42 & 0.09 & Low Risk \\
\hline Clark's Grebe Male & 0.29 & Low Risk & Smallmouth Bass & 0.59 & 0.13 & Low Risk \\
\hline Clark's Grebe Female & 0.23 & Low Risk & Brown Trout & 0.12 & 0.03 & Low Risk \\
\hline Western Grebe Male & 0.23 & Low Risk & Rainbow Trout & 0.19 & 0.04 & Low Risk \\
\hline $\begin{array}{l}\text { Western Grebe } \\
\text { Female }\end{array}$ & 0.18 & Low Risk & Eagle Lake Trout & 0.19 & 0.04 & Low Risk \\
\hline & $\begin{array}{c}\text { Grebe Eggs } \\
(\mu \mathrm{g} / \mathrm{g} \text { fww) }\end{array}$ & Risk to Wildife & & & & \\
\hline All Grebes & 0.04 & Low Risk & & & & \\
\hline
\end{tabular}

Figure 12. Example of our predictive tool for use by natural resource managers using Big Lake specific data. Tool users will enter total mercury ( $\mathrm{THg}$ ) concentrations (in micrograms per gram dry weight $[\mu \mathrm{g} / \mathrm{g} \mathrm{dw}]$ ) in prey fish, date sampled, and the specific lake's attributes (lake area, perimeter, and elevation), and our tool will estimate the predicted THg concentrations in grebe blood, grebe eggs, and sport fish. Our tool then uses these estimated values to assess the relative risk to wildlife and sport fish by comparing the estimated THg concentrations to published toxicity benchmarks. In this example, THg concentrations in prey fish at Big Lake are very low, and thus the tool estimates that wildlife and sport fish are at low risk of potential mercury impairment. 

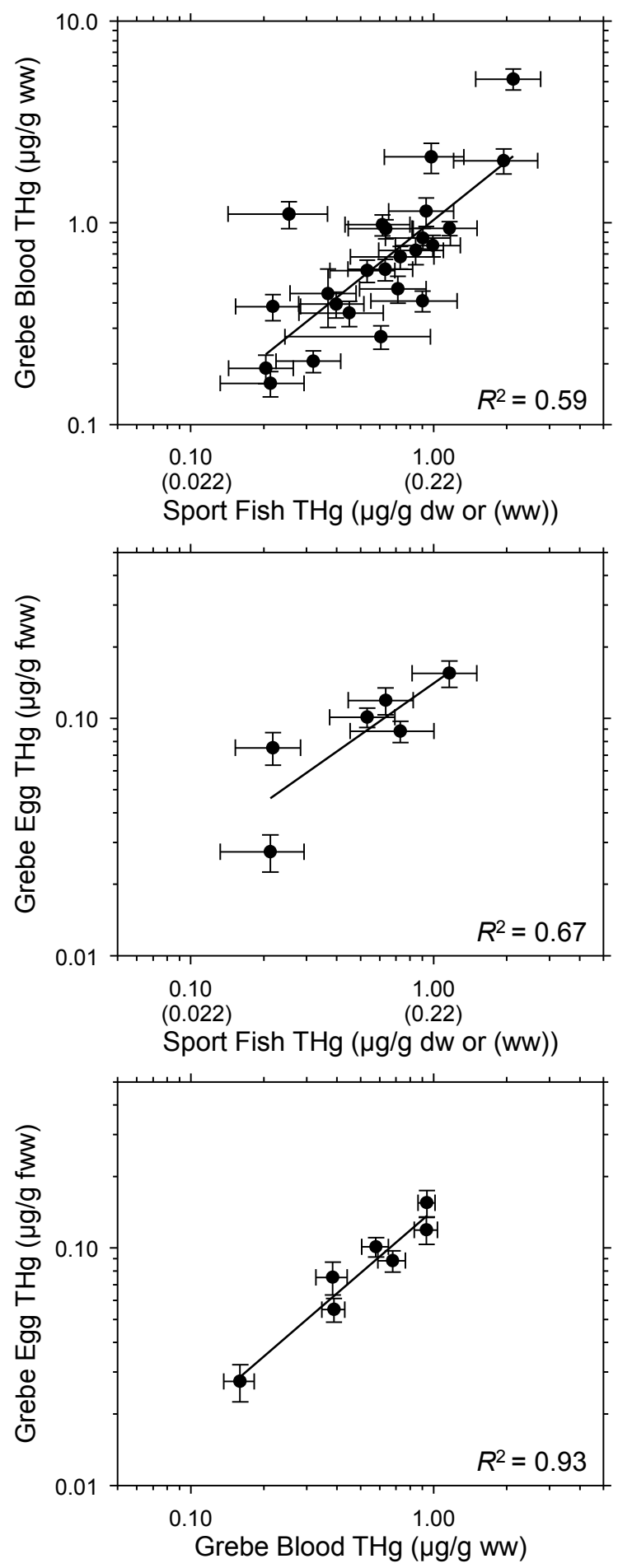

Figure 13. Graphs showing total mercury $(\mathrm{THg})$ concentrations in grebe blood versus THg concentrations (in micrograms per gram dry weight [ $\mu \mathrm{g} / \mathrm{g} \mathrm{dw}$ ] [top row $X$ axis] or $\mu \mathrm{g} / \mathrm{g}$ wet weight [ww] [bottom row $X$ axis]) in sport fish (top panel), grebe eggs versus sport fish (middle panel), and grebe eggs versus grebe blood (bottom panel) at up to 25 lakes in California, 2012-13. Values are least squares means \pm standard errors from separate models accounting for (1) grebe blood model: species and sex with lake as a random effect; (2) grebe egg model: species and egg type with lake as a random effect; and (3) sport fish model: species, total length, and species $\times$ length interaction with lake as a random effect. 
Table 1. Sample size and relative risk of blood mercury to female and male western and Clark's grebes by lake in California, 2012-13.

[ $\mu \mathrm{g} / \mathrm{g} w \mathrm{w}$, microgram per gram wet weight]

\begin{tabular}{|c|c|c|c|c|c|c|c|c|c|}
\hline \multirow[b]{2}{*}{ Lake } & \multirow[b]{2}{*}{ Year } & \multirow[b]{2}{*}{ Dates sampled } & \multicolumn{2}{|c|}{ Western grebe } & \multicolumn{2}{|c|}{ Clark's grebe } & \multirow{2}{*}{$\begin{array}{c}\text { Total } \\
\text { number } \\
\text { sampled }\end{array}$} & \multirow{2}{*}{$\begin{array}{l}\text { Moderate } \\
\text { risk }(\geq 1.0 \\
\mu g / g ~ w w)\end{array}$} & \multirow{2}{*}{$\begin{array}{c}\text { High risk } \\
(\geq 3.0 \\
\mu \mathrm{g} / \mathrm{g} \text { ww) }\end{array}$} \\
\hline & & & Female & Male & Female & Male & & & \\
\hline Antelope Lake & 2013 & $8 / 23 / 2013-8 / 25 / 2013$ & 6 & 5 & 0 & 0 & 11 & $0 \%$ & $0 \%$ \\
\hline Black Butte Lake & 2012 & $10 / 3 / 2012-10 / 6 / 2012$ & 7 & 4 & 5 & 1 & 17 & $0 \%$ & $0 \%$ \\
\hline Bridgeport Reservoir & 2012 & 6/6/2012-6/9/2012 & 2 & 5 & 2 & 1 & 10 & $60 \%$ & $10 \%$ \\
\hline Clear Lake & 2012 & $5 / 14 / 2012-5 / 17 / 2012$ & 17 & 10 & 9 & 2 & 38 & $32 \%$ & $8 \%$ \\
\hline Eagle Lake & 2012 & 9/4/2012-9/6/2012 & 7 & 6 & 0 & 1 & 14 & $7 \%$ & $0 \%$ \\
\hline East Park Reservoir & 2012 & 6/28/2012-6/30/2012 & 4 & 5 & 6 & 5 & 20 & $50 \%$ & $0 \%$ \\
\hline Lake Almanor & 2012 & 7/31/2012-8/3/2012 & 4 & 11 & 0 & 0 & 15 & $13 \%$ & $0 \%$ \\
\hline Lake Berryessa & 2012 & $5 / 22 / 2012-5 / 25 / 2012$ & 0 & 6 & 6 & 5 & 17 & $100 \%$ & $88 \%$ \\
\hline Lake Cachuma & 2012 & $6 / 3 / 2012-6 / 5 / 2012$ & 6 & 7 & 1 & 2 & 16 & $13 \%$ & $0 \%$ \\
\hline Lake Casitas & 2013 & 6/3/2013-6/4/2013 & 3 & 8 & 4 & 2 & 17 & $41 \%$ & $0 \%$ \\
\hline Lake Davis & 2012 & $7 / 16 / 2012-7 / 19 / 2012$ & 7 & 5 & 0 & 0 & 12 & $0 \%$ & $0 \%$ \\
\hline Lake Hodges & 2013 & $5 / 3 / 2013-5 / 5 / 2013$ & 2 & 7 & 3 & 3 & 15 & $0 \%$ & $0 \%$ \\
\hline Lake Mendocino & 2013 & $7 / 29 / 2013-8 / 2 / 2013$ & 1 & 3 & 1 & 5 & 10 & $50 \%$ & $0 \%$ \\
\hline Lake San Antonio & 2012 & $5 / 31 / 2012-6 / 2 / 2012$ & 3 & 10 & 3 & 1 & 17 & $47 \%$ & $6 \%$ \\
\hline Lake Success & 2013 & $6 / 8 / 2013-6 / 9 / 2013$ & 8 & 2 & 2 & 4 & 16 & $0 \%$ & $0 \%$ \\
\hline Lower Otay Reservoir & 2013 & $4 / 30 / 2013-5 / 2 / 2013$ & 5 & 3 & 1 & 2 & 11 & $0 \%$ & $0 \%$ \\
\hline O'Neill Forebay & 2012 & 9/20/2012-9/21/2012 & 1 & 0 & 0 & 1 & 2 & $0 \%$ & $0 \%$ \\
\hline Perris Reservoir & 2013 & 5/8/2013-5/9/2013 & 4 & 4 & 1 & 0 & 9 & $0 \%$ & $0 \%$ \\
\hline Stony Gorge Reservoir & 2013 & $8 / 13 / 2013-8 / 27 / 2013$ & 0 & 3 & 3 & 4 & 10 & $0 \%$ & $0 \%$ \\
\hline Thermalito Afterbay & 2012 & 7/19/2012-7/21/2012 & 7 & 5 & 1 & 2 & 15 & $0 \%$ & $0 \%$ \\
\hline Topaz Lake & 2013 & 6/26/2013-6/28/2013 & 2 & 3 & 3 & 0 & 8 & $100 \%$ & $13 \%$ \\
\hline Tule Lake & 2013 & $7 / 15 / 2013-7 / 16 / 2013$ & 9 & 7 & 2 & 3 & 21 & $5 \%$ & $0 \%$ \\
\hline All Lakes & 2012-2013 & $2012-2013$ & 117 & 136 & 54 & 47 & 354 & $28 \%$ & $6 \%$ \\
\hline
\end{tabular}


Table 2. Sample size of randomly sampled and abandoned eggs for western and Clark's grebes by lake in California, 2012-13.

\begin{tabular}{|c|c|c|c|c|c|c|c|c|c|}
\hline \multirow[b]{2}{*}{ Lake } & \multirow[b]{2}{*}{ Year } & \multirow[b]{2}{*}{ Date(s) sampled } & \multicolumn{2}{|c|}{ Western grebe } & \multicolumn{2}{|c|}{ Clark's grebe } & \multicolumn{2}{|c|}{$\begin{array}{c}\text { Grebe species } \\
\text { unknown }\end{array}$} & \multirow[b]{2}{*}{ Total } \\
\hline & & & Random & Abandoned & Random & Abandoned & Random & Abandoned & \\
\hline Antelope Lake & 2013 & $8 / 1 / 2013-8 / 24 / 2013$ & 5 & 1 & 0 & 0 & 0 & 1 & 7 \\
\hline Big Lake & 2013 & $7 / 19 / 2013$ & 1 & 0 & 0 & 0 & 1 & 4 & 6 \\
\hline Clear Lake & 2012 & $7 / 24 / 2012$ & 15 & 0 & 0 & 0 & 0 & 0 & 15 \\
\hline East Park Reservoir & 2012 & $7 / 24 / 2012$ & 6 & 0 & 5 & 2 & 2 & 0 & 15 \\
\hline Lake Almanor & 2012 & $7 / 31 / 2012-8 / 29 / 2012$ & 13 & 0 & 2 & 0 & 0 & 5 & 20 \\
\hline Thermalito Afterbay & 2012 & $8 / 6 / 2012-9 / 13 / 2012$ & 12 & 0 & 3 & 0 & 0 & 8 & 23 \\
\hline Tule Lake & 2013 & $7 / 17 / 2013$ & 10 & 0 & 3 & 0 & 0 & 2 & 15 \\
\hline All Lakes & 2012-2013 & 2012-2013 & 62 & 1 & 13 & 2 & 3 & 20 & 101 \\
\hline
\end{tabular}


Table 3. Common names, scientific names, sample sizes, and proportion of prey fish species sampled in California, 2012-13.

\begin{tabular}{llcc}
\hline \multicolumn{1}{c}{ Common name } & \multicolumn{1}{c}{ Scientific name } & Sample size & $\begin{array}{c}\text { Percentage of } \\
\text { total prey fish } \\
\text { sampled }\end{array}$ \\
\hline Bluegill & Lepomis macrochirus & 150 & 30 \\
Mississippi silverside & Menidia audens & 110 & 22 \\
Threadfin shad & Dorosoma petenense & 70 & 14 \\
Golden shiner & Notemigonus crysoleucas & 40 & 8 \\
Sacramento perch & Archoplites interruptus & 27 & 5 \\
Sacramento sucker & Catostomus occidentalis & 20 & 4 \\
Tui chub & Gila bicolor & 18 & 4 \\
Blue chub & Gila coerulea & 10 & 2 \\
Hitch & Lavinia exilicauda & 10 & 2 \\
Largemouth bass & Micropterus salmoides & 10 & 2 \\
Pumpkinseed sunfish & Lepomis gibbosus & 10 & 2 \\
Redear sunfish & Lepomis microlophis & 10 & 2 \\
Smallmouth bass & Micropterus dolomieu & 10 & 2 \\
Tahoe sucker & Catostomus tahoensis & 10 & 2 \\
\hline
\end{tabular}


Table 4. Species and number of prey fish sampled by lake in California, 2012-13.

\begin{tabular}{|c|c|c|c|c|c|c|c|c|c|c|}
\hline Lake & Year & Date(s) sampled & Silverside & $\begin{array}{c}\text { Threadfin } \\
\text { shad }\end{array}$ & $\begin{array}{l}\text { Golden } \\
\text { shiner }\end{array}$ & $\begin{array}{c}\text { Tui } \\
\text { chub }\end{array}$ & $\begin{array}{l}\text { Blue } \\
\text { chub }\end{array}$ & Hitch & Bluegill & $\begin{array}{c}\text { Sacramento } \\
\text { perch }\end{array}$ \\
\hline Antelope Lake & 2013 & $9 / 4 / 2013$ & & & 10 & & & & & \\
\hline Big Lake & 2013 & $7 / 23 / 2013$ & & & & & & 10 & 10 & \\
\hline Black Butte Lake & 2012 & $10 / 10 / 2012$ & 10 & 10 & & & & & & \\
\hline Bridgeport Reservoir & 2012 & $6 / 26 / 2012,8 / 28 / 2012$ & & & 10 & & & & & 10 \\
\hline Clear Lake & 2012 & $5 / 30 / 2012$ & 10 & & & & & & 10 & \\
\hline Crowley Lake & 2012 & $8 / 27 / 2012$ & & & 10 & & & & & 10 \\
\hline Eagle Lake & 2012 & $9 / 4 / 2012$ & & & & 10 & & & & \\
\hline East Park Reservoir & 2012 & $7 / 2 / 2012$ & 10 & & & & & & 10 & \\
\hline Lake Almanor & 2012 & $8 / 1 / 2012$ & 10 & & & & & & & \\
\hline Lake Berryessa & 2012 & $5 / 31 / 2012$ & 10 & & & & & & 10 & \\
\hline Lake Cachuma & 2012 & $6 / 20 / 2012$ & & 10 & & & & & 10 & \\
\hline Lake Casitas & 2013 & $6 / 10 / 2013$ & & 10 & & & & & 10 & \\
\hline Lake Davis & 2012 & $7 / 24 / 2012$ & & & 10 & & & & & \\
\hline Lake Hennessey & 2013 & $8 / 29 / 2013$ & 10 & 5 & & & & & 10 & \\
\hline Lake Hodges & 2013 & $5 / 15 / 2013$ & & 10 & & & & & 10 & \\
\hline Lake Mendocino & 2013 & $7 / 30 / 2013$ & 10 & 5 & & & & & 10 & \\
\hline Lake San Antonio & 2012 & $6 / 7 / 2012$ & 10 & & & & & & 10 & \\
\hline Lake Success & 2013 & $6 / 11 / 2013$ & & 10 & & & & & 10 & \\
\hline Lower Otay Reservoir & 2013 & $5 / 14 / 2013$ & & & & & & & 10 & \\
\hline O'Neill Forebay & 2012 & $9 / 20 / 2012$ & 10 & & & & & & & \\
\hline Perris Reservoir & 2013 & $5 / 13 / 2013$ & 10 & & & & & & 10 & \\
\hline Stony Gorge Reservoir & 2013 & $8 / 18 / 2013$ & & 10 & & & & & 10 & \\
\hline Thermalito Afterbay & 2012 & $7 / 2 / 2012$ & 10 & & & & & & 10 & \\
\hline Topaz Lake & 2013 & $7 / 8 / 2013$ & & & & & & & & \\
\hline Tule Lake & 2013 & $7 / 31 / 2013$ & & & & 8 & 10 & & & 7 \\
\hline All Lakes & 2012-2013 & 2012-2013 & 110 & 70 & 40 & 18 & 10 & 10 & 150 & 27 \\
\hline
\end{tabular}

Continued on next page 
Table 4. Species and number of prey fish sampled by lake in California, 2012-13.-Continued

\begin{tabular}{|c|c|c|c|c|c|c|c|c|c|}
\hline Lake & Year & Date(s) sampled & Pumpkinseed & $\begin{array}{l}\text { Redear } \\
\text { sunfish }\end{array}$ & $\begin{array}{l}\text { Largemouth } \\
\text { bass }\end{array}$ & $\begin{array}{c}\text { Smallmouth } \\
\text { bass }\end{array}$ & $\begin{array}{l}\text { Sacramento } \\
\text { sucker }\end{array}$ & $\begin{array}{l}\text { Tahoe } \\
\text { sucker }\end{array}$ & $\begin{array}{c}\text { All } \\
\text { species }\end{array}$ \\
\hline Antelope Lake & 2013 & 9/4/2013 & & 10 & & & & & 20 \\
\hline Big Lake & 2013 & $7 / 23 / 2013$ & & & & & & & 20 \\
\hline Black Butte Lake & 2012 & 10/10/2012 & & & & & & & 20 \\
\hline Bridgeport Reservoir & 2012 & $6 / 26 / 2012,8 / 28 / 2012$ & & & & & & & 20 \\
\hline Clear Lake & 2012 & $5 / 30 / 2012$ & & & & & & & 20 \\
\hline Crowley Lake & 2012 & $8 / 27 / 2012$ & & & & & & & 20 \\
\hline Eagle Lake & 2012 & 9/4/2012 & & & & & & 10 & 20 \\
\hline East Park Reservoir & 2012 & 7/2/2012 & & & & & & & 20 \\
\hline Lake Almanor & 2012 & $8 / 1 / 2012$ & & & & & 10 & & 20 \\
\hline Lake Berryessa & 2012 & $5 / 31 / 2012$ & & & & & & & 20 \\
\hline Lake Cachuma & 2012 & $6 / 20 / 2012$ & & & & & & & 20 \\
\hline Lake Casitas & 2013 & $6 / 10 / 2013$ & & & & & & & 20 \\
\hline Lake Davis & 2012 & $7 / 24 / 2012$ & 10 & & & & & & 20 \\
\hline Lake Hennessey & 2013 & $8 / 29 / 2013$ & & & & & & & 25 \\
\hline Lake Hodges & 2013 & $5 / 15 / 2013$ & & & & & & & 20 \\
\hline Lake Mendocino & 2013 & $7 / 30 / 2013$ & & & & & & & 25 \\
\hline Lake San Antonio & 2012 & $6 / 7 / 2012$ & & & & & & & 20 \\
\hline Lake Success & 2013 & $6 / 11 / 2013$ & & & & & & & 20 \\
\hline Lower Otay Reservoir & 2013 & $5 / 14 / 2013$ & & & 10 & & & & 20 \\
\hline O'Neill Forebay & 2012 & $9 / 20 / 2012$ & & & & & & & 10 \\
\hline Perris Reservoir & 2013 & $5 / 13 / 2013$ & & & & & & & 20 \\
\hline Stony Gorge Reservoir & 2013 & $8 / 18 / 2013$ & & & & & & & 20 \\
\hline Thermalito Afterbay & 2012 & $7 / 2 / 2012$ & & & & & & & 20 \\
\hline Topaz Lake & 2013 & 7/8/2013 & & & & 10 & 10 & & 20 \\
\hline Tule Lake & 2013 & $7 / 31 / 2013$ & & & & & & & 25 \\
\hline All Lakes & 2012-2013 & 2012-2013 & 10 & 10 & 10 & 10 & 20 & 10 & 505 \\
\hline
\end{tabular}


Table 5. Common names, scientific names, sample sizes, and proportion of sport fish species sampled in California, 2012-13.

\begin{tabular}{llcc}
\hline \multicolumn{1}{c}{ Common name } & \multicolumn{1}{c}{ Scientific name } & Sample size & $\begin{array}{c}\text { Percentage of total sport } \\
\text { fish sampled }\end{array}$ \\
\hline Largemouth bass & Micropterus salmoides & 156 & 68 \\
Rainbow trout & Oncorhynchus mykiss & 40 & 17 \\
Brown trout & Salmo trutta & 12 & 5 \\
Smallmouth bass & Micropterus dolomieu & 12 & 5 \\
Eagle Lake rainbow trout & Oncorhynchus mykiss aquilarum & 10 & 4 \\
\hline
\end{tabular}


Table 6. Species and number of sport fish sampled by lake in California, 2012-13.

\begin{tabular}{|c|c|c|c|c|c|c|c|c|}
\hline Lake & Year & Date(s) sampled & $\begin{array}{l}\text { Largemouth } \\
\text { bass }\end{array}$ & $\begin{array}{c}\text { Smallmouth } \\
\text { bass }\end{array}$ & $\begin{array}{c}\text { Rainbow } \\
\text { trout }\end{array}$ & Brown trout & $\begin{array}{c}\text { Eagle Lake } \\
\text { rainbow } \\
\text { trout }\end{array}$ & All species \\
\hline Antelope Lake & 2013 & $9 / 4 / 2013$ & 10 & & & & & 10 \\
\hline Big Lake & 2013 & $7 / 23 / 2013$ & & & 10 & & & 10 \\
\hline Black Butte Lake & 2012 & $10 / 10 / 2012$ & & 10 & & & & 10 \\
\hline Bridgeport Reservoir & 2012 & $8 / 28 / 2012$ & & & & 10 & & 10 \\
\hline Clear Lake & 2012 & $5 / 30 / 2012$ & 10 & & & & & 10 \\
\hline Crowley Lake & 2012 & $8 / 27 / 2012$ & & & 10 & & & 10 \\
\hline Eagle Lake & 2012 & $9 / 7 / 2012-9 / 15 / 2012$ & & & & & 10 & 10 \\
\hline East Park Reservoir & 2012 & $7 / 2 / 2012$ & 10 & & & & & 10 \\
\hline Lake Almanor & 2012 & $8 / 1 / 2012$ & & & 10 & & & 10 \\
\hline Lake Berryessa & 2012 & $5 / 31 / 2012$ & 10 & & & & & 10 \\
\hline Lake Cachuma & 2012 & $6 / 20 / 2012$ & 10 & & & & & 10 \\
\hline Lake Casitas & 2013 & $6 / 10 / 2013$ & 10 & & & & & 10 \\
\hline Lake Davis & 2012 & $7 / 24 / 2012$ & & & 10 & & & 10 \\
\hline Lake Hennessey & 2013 & $8 / 29 / 2013$ & 10 & & & & & 10 \\
\hline Lake Hodges & 2013 & $5 / 15 / 2013$ & 10 & & & & & 10 \\
\hline Lake Mendocino & 2013 & $7 / 30 / 2013$ & 10 & & & & & 10 \\
\hline Lake San Antonio & 2012 & $6 / 7 / 2012$ & 10 & & & & & 10 \\
\hline Lake Success & 2013 & $6 / 11 / 2013$ & 10 & & & & & 10 \\
\hline Lower Otay Reservoir & 2013 & $5 / 14 / 2013$ & 10 & & & & & 10 \\
\hline O'Neill Forebay & 2012 & $9 / 20 / 2012$ & 8 & & & & & 8 \\
\hline Perris Reservoir & 2013 & $5 / 13 / 2013$ & 10 & & & & & 10 \\
\hline Stony Gorge Reservoir & 2013 & $8 / 18 / 2013$ & 8 & & & & & 8 \\
\hline Thermalito Afterbay & 2012 & $7 / 2 / 2012$ & 10 & & & & & 10 \\
\hline Topaz Lake & 2013 & $7 / 8 / 2013$ & & 2 & & 2 & & 4 \\
\hline All Lakes & 2012-2013 & 2012-2013 & 156 & 12 & 40 & 12 & 10 & 230 \\
\hline
\end{tabular}


Table 7. Location, size, perimeter, elevation, and shape index for each of the 25 lakes sampled in California, 201213.

[ha, hectare, km, kilometer, m, meter]

\begin{tabular}{|c|c|c|c|c|c|c|c|}
\hline Lake & County & Easting & Northing & $\begin{array}{l}\text { Surface area } \\
\text { (ha) }\end{array}$ & $\begin{array}{c}\text { Perimeter } \\
(\mathbf{k m})\end{array}$ & $\begin{array}{l}\text { Elevation } \\
(\mathrm{m})\end{array}$ & $\begin{array}{c}\text { Lake shape } \\
\text { index }\end{array}$ \\
\hline Antelope Lake & Plumas & 704810 & 4450906 & 383.89 & 31.74 & $1,525.0$ & 4.050 \\
\hline Big Lake & Shasta & 632011 & 4552145 & 703.26 & 36.67 & $1,007.4$ & 3.457 \\
\hline Black Butte Lake & Tehama\&Glenn & 553604 & 4403857 & $1,742.82$ & 81.11 & 145.0 & 4.858 \\
\hline Bridgeport Reservoir & Mono & 829457 & 4244854 & $1,036.69$ & 30.47 & $1,967.5$ & 2.366 \\
\hline Clear Lake & Lake & 518373 & 4320269 & $16,005.75$ & 172.93 & 405.0 & 3.417 \\
\hline Crowley Lake & Mono & 876066 & 4171627 & $1,680.02$ & 39.79 & $2,062.0$ & 2.427 \\
\hline Eagle Lake & Lassen & 690906 & 4501329 & $9,866.18$ & 102.48 & $1,558.0$ & 2.579 \\
\hline East Park Reservoir & Colusa & 542605 & 4354871 & 672.77 & 52.08 & 366.0 & 5.020 \\
\hline Lake Almanor & Plumas & 657158 & 4457388 & $10,273.82$ & 100.63 & $1,371.6$ & 2.482 \\
\hline Lake Berryessa & Napa & 566309 & 4271951 & $7,553.16$ & 255.33 & 133.8 & 7.345 \\
\hline Lake Cachuma & Santa Barbara & 781156 & 3830425 & $1,283.80$ & 67.29 & 229.8 & 4.695 \\
\hline Lake Casitas & Ventura & 836215 & 3811714 & 982.47 & 48.94 & 158.0 & 3.904 \\
\hline Lake Davis & Plumas & 712552 & 4420841 & $1,647.39$ & 67.69 & $1,761.0$ & 4.169 \\
\hline Lake Hennessey & Napa & 554800 & 4260477 & 307.77 & 16.11 & 97.0 & 2.295 \\
\hline Lake Hodges & San Diego & 1050421 & 3673333 & 173.34 & 17.09 & 84.0 & 3.246 \\
\hline Lake Mendocino & Mendocino & 485498 & 4340858 & 686.73 & 26.02 & 226.0 & 2.482 \\
\hline Lake San Antonio & Monterey & 682898 & 3968691 & $2,176.78$ & 84.58 & 238.0 & 4.532 \\
\hline Lake Success & Tulare & 868056 & 4000868 & $1,002.65$ & 43.53 & 200.0 & 3.437 \\
\hline Lower Otay Reservoir & San Diego & 1070821 & 3626336 & 445.20 & 21.87 & 151.0 & 2.592 \\
\hline O'Neill Forebay & Merced & 673520 & 4106015 & 908.72 & 23.60 & 67.1 & 1.957 \\
\hline Perris Reservoir & Riverside & 1039162 & 3761590 & 782.83 & 16.81 & 478.0 & 1.502 \\
\hline Stony Gorge Reservoir & Glenn & 540906 & 4378248 & 559.06 & 33.18 & 257.0 & 3.508 \\
\hline Thermalito Afterbay & Butte & 614993 & 4370806 & $1,632.91$ & 66.90 & 42.4 & 4.139 \\
\hline Topaz Lake & Douglas & 802027 & 4286599 & 890.21 & 20.14 & $1,527.0$ & 1.687 \\
\hline Tule Lake & Siskiyou & 621971 & 4639908 & $3,070.44$ & 79.25 & $1,229.3$ & 3.576 \\
\hline
\end{tabular}


Table 8. Ranking of candidate model set describing western grebe and Clark's grebe blood total mercury (THg) concentrations ( $n=353$ grebes) at 25 lakes, California, 2012-13.

[Akaike's Information Criterion (AICc) was used to rank models. Lake was a random effect in all models. We present only the top models that were within $\Delta \mathrm{AIC} c$ $\leq 2$, the null model (shaded), and each model that was similar to the top model except one of the variables in the top model was removed (only shaded if $\Delta$ AIC $c>$ 2). Model: +, an additive effect. $\boldsymbol{k}$ : Number of parameters in the model, including the intercept. $-\mathbf{2 l o g} \boldsymbol{L}:-2 \log$-likelihood of the model. $\triangle \boldsymbol{A I C \boldsymbol { c }}$ : Difference in the value between $\mathrm{AIC} c$ of the current model and the value for the most parsimonious model. $\boldsymbol{w}_{i}$ : Akaike weight, the likelihood of the model given the data, relative to other models in the candidate set (model weights sum to 1.0). Evidence ratio: Weight of evidence that the top model is better than the selected model, given the candidate model set]

\begin{tabular}{|c|c|c|c|c|c|c|c|}
\hline Model & $k$ & $-2 \log L$ & $\mathrm{AICc}$ & $\triangle \mathrm{AICc}$ & $w_{\mathbf{i}}$ & $\begin{array}{c}\text { Evidence } \\
\text { ratio }\end{array}$ & $\begin{array}{c}\text { Cumulative } \\
\text { weight }\end{array}$ \\
\hline THg Prey Fish + Species + Sex + Molt + Lake Perimeter & 7 & 545.25 & 559.58 & 0.00 & 0.02 & 1.00 & 0.02 \\
\hline THg Prey Fish + Species + Sex + Lake Perimeter & 6 & 547.40 & 559.64 & 0.06 & 0.02 & 1.03 & 0.04 \\
\hline THg Prey Fish + Species + Sex + Molt + Lake Perimeter + Molt $^{2}$ & 8 & 543.61 & 560.03 & 0.45 & 0.02 & 1.25 & 0.06 \\
\hline THg Prey Fish + Species + Sex + Date + Lake Perimeter + Date $^{2}$ & 8 & 543.77 & 560.19 & 0.62 & 0.02 & 1.36 & 0.08 \\
\hline THg Prey Fish + Species + Sex + Molt + Lake Perimeter + Lake Shape & 8 & 544.26 & 560.67 & 1.10 & 0.01 & 1.73 & 0.09 \\
\hline $\mathrm{THg}$ Prey Fish + Species + Sex + Date + Molt + Lake Perimeter + Date $^{2}$ & 9 & 542.17 & 560.69 & 1.12 & 0.01 & 1.75 & 0.11 \\
\hline THg Prey Fish + Species + Sex + Lake Perimeter + Lake Shape & 7 & 546.49 & 560.81 & 1.24 & 0.01 & 1.85 & 0.12 \\
\hline THg Prey Fish + Species + Sex + Molt + Lake Perimeter + Lake Shape + Molt $^{2}$ & 9 & 542.55 & 561.08 & 1.50 & 0.01 & 2.12 & 0.13 \\
\hline THg Prey Fish + Species + Sex + Date + Lake Perimeter + Lake Shape + Date $^{2}$ & 9 & 542.68 & 561.20 & 1.62 & 0.01 & 2.25 & 0.14 \\
\hline $\mathrm{THg}$ Prey Fish + Species + Sex + Date + Lake Perimeter + Lake Area + Lake Shape + Date $^{2}$ & 10 & 540.74 & 561.39 & 1.81 & 0.01 & 2.47 & 0.15 \\
\hline THg Prey Fish + Species + Sex + Lake Perimeter + Lake Area + Lake Shape & 8 & 544.97 & 561.39 & 1.81 & 0.01 & 2.47 & 0.16 \\
\hline THg Prey Fish + Species + Sex + Molt + Lake Perimeter + Lake Area + Lake Shape & 9 & 542.88 & 561.41 & 1.83 & 0.01 & 2.50 & 0.17 \\
\hline THg Prey Fish + Species + Sex + Date + Lake Perimeter & 7 & 547.09 & 561.42 & 1.84 & 0.01 & 2.51 & 0.17 \\
\hline THg Prey Fish + Species + Sex + Date + Molt + Lake Perimeter + Date $^{2}+$ Molt $^{2}$ & 10 & 540.80 & 561.45 & 1.87 & 0.01 & 2.55 & 0.18 \\
\hline THg Prey Fish + Species + Sex + Body Condition + Lake Perimeter & 7 & 547.15 & 561.47 & 1.90 & 0.01 & 2.58 & 0.19 \\
\hline THg Prey Fish + Species + Sex + Molt + Lake Area & 7 & 547.23 & 561.55 & 1.97 & 0.01 & 2.68 & 0.20 \\
\hline THg Prey Fish + Species + Sex + Date + Molt + Lake Perimeter + Lake Shape + Date $^{2}$ & 10 & 540.95 & 561.59 & 2.01 & 0.01 & 2.74 & 0.21 \\
\hline THg Prey Fish + Species + Sex + Molt & 6 & 550.76 & 563.00 & 3.42 & 0.00 & 5.54 & 0.48 \\
\hline THg Prey Fish + Sex + Molt + Lake Perimeter & 6 & 558.86 & 571.10 & 11.53 & 0.00 & 318.27 & 0.99 \\
\hline $\mathrm{THg}$ Prey Fish + Species + Molt + Lake Perimeter & 6 & 559.45 & 571.70 & 12.12 & 0.00 & 428.11 & 0.99 \\
\hline Species + Sex + Molt + Lake Perimeter & 6 & 576.77 & 589.02 & 29.44 & 0.00 & $2.47 \times 10^{6}$ & 1.00 \\
\hline Null (Lake as random effect) & 2 & 608.62 & 612.66 & 53.08 & 0.00 & $3.36 \times 10^{11}$ & 1.00 \\
\hline
\end{tabular}


Table 9. Ranking of candidate model set describing western grebe and Clark's grebe egg total mercury (THg) concentrations ( $n=101$ eggs) at seven lakes, California, 2012-13.

[Akaike's Information Criterion (AICc) was used to rank models. Lake was a random effect in all models. We present only the top models that were within $\triangle \mathrm{AIC} c$ less than or equal to 2, the null model (shaded), and each model that was similar to the top model except one of the variables in the top model was removed (only shaded if $\Delta \mathrm{AIC} c$ greater than 2). Model: + , an additive effect. $\boldsymbol{k}$ : Number of parameters in the model, including the intercept. -2logL: $-2 \log$-likelihood of the model.

$\triangle \mathrm{AIC} c$ : Difference in the value between AIC $c$ of the current model and the value for the most parsimonious model. $\boldsymbol{w}_{i}$ : Akaike weight, likelihood of the model given the data, relative to other models in the candidate set (model weights sum to 1.0). Evidence ratio: Weight of evidence that the top model is better than the selected model, given the candidate model set]

\begin{tabular}{|c|c|c|c|c|c|c|c|}
\hline Model & $k$ & $-2 \log L$ & $\mathrm{AlCc}$ & $\triangle \mathrm{AlCc}$ & $w_{\mathrm{i}}$ & $\begin{array}{l}\text { Evidence } \\
\text { ratio }\end{array}$ & $\begin{array}{c}\text { Cumulative } \\
\text { weight }\end{array}$ \\
\hline THg Prey Fish + Date + Lake Perimeter & 5 & 110.29 & 120.92 & 0.00 & 0.04 & 1.00 & 0.04 \\
\hline THg Prey Fish & 3 & 114.71 & 120.95 & 0.03 & 0.04 & 1.02 & 0.08 \\
\hline THg Prey Fish + Lake Perimeter & 4 & 112.95 & 121.37 & 0.45 & 0.03 & 1.25 & 0.11 \\
\hline THg Prey Fish + Date & 4 & 113.23 & 121.65 & 0.73 & 0.03 & 1.44 & 0.14 \\
\hline THg Prey Fish + Lake Area & 4 & 113.35 & 121.76 & 0.84 & 0.03 & 1.52 & 0.17 \\
\hline THg Prey Fish + Date + Lake Area & 5 & 111.25 & 121.88 & 0.96 & 0.02 & 1.62 & 0.19 \\
\hline THg Prey Fish + Lake Shape & 4 & 113.51 & 121.93 & 1.01 & 0.02 & 1.65 & 0.21 \\
\hline THg Prey Fish + Egg Type & 4 & 113.57 & 121.99 & 1.06 & 0.02 & 1.70 & 0.24 \\
\hline THg Prey Fish + Egg Type + Lake Perimeter & 5 & 111.75 & 122.38 & 1.46 & 0.02 & 2.07 & 0.26 \\
\hline Date + Lake Area + Lake Shape & 5 & 111.96 & 122.59 & 1.67 & 0.02 & 2.30 & 0.28 \\
\hline THg Prey Fish + Date + Lake Perimeter + Lake Area & 6 & 109.84 & 122.73 & 1.81 & 0.02 & 2.47 & 0.29 \\
\hline THg Prey Fish + Date + Lake Shape & 5 & 112.17 & 122.80 & 1.88 & 0.02 & 2.56 & 0.31 \\
\hline $\mathrm{THg}$ Prey Fish + Date + Lake Perimeter + Date $^{2}$ & 6 & 109.94 & 122.83 & 1.91 & 0.02 & 2.60 & 0.32 \\
\hline THg Prey Fish + Egg Type + Lake Area & 5 & 112.20 & 122.83 & 1.91 & 0.02 & 2.60 & 0.34 \\
\hline THg Prey Fish + Date + Date $^{2}$ & 5 & 112.22 & 122.86 & 1.93 & 0.02 & 2.63 & 0.35 \\
\hline THg Prey Fish + Date + Lake Perimeter + Lake Shape & 6 & 109.96 & 122.86 & 1.94 & 0.02 & 2.63 & 0.37 \\
\hline THg Prey Fish + Egg Type + Date + Lake Perimeter & 6 & 110.21 & 123.11 & 2.19 & 0.01 & 2.98 & 0.38 \\
\hline Date + Lake Perimeter & 4 & 119.88 & 128.30 & 7.37 & 0.00 & 39.92 & 0.94 \\
\hline Null (Lake as random effect) & 2 & 125.43 & 129.55 & 8.63 & 0.00 & 74.72 & 0.97 \\
\hline
\end{tabular}


Table 10. Ranking of candidate model set describing sport fish total mercury (THg) concentrations ( $n=230$ fish) at 24 lakes in California, $2012-13$.

[Akaike's Information Criterion (AICc) was used to rank models. Lake was a random effect in all models. We present only the top models that were within $\Delta \mathrm{AIC} c$ less than or equal to 2, the null model (shaded), and each model that was similar to the top model except one of the variables in the top model was removed (only shaded if $\triangle \mathrm{AIC} c$ greater than 2). Model: + an additive effect; $\times$, an interaction. $\boldsymbol{k}$ : Number of parameters in the model, including the intercept. $\mathbf{- 2 l o g L}$ : Indicates the $-2 \log$-likelihood of the model. $\triangle \mathbf{A I C} \boldsymbol{c}$ : Difference in the value between AIC $c$ of the current model and the value for the most parsimonious model. $\boldsymbol{w}_{i}$ : Akaike weight, represents the likelihood of the model given the data, relative to other models in the candidate set (model weights sum to 1.0). Evidence ratio: Represents the weight of evidence that the top model is better than the selected model, given the candidate model set]

\begin{tabular}{|c|c|c|c|c|c|c|c|}
\hline Model & $k$ & $-2 \log \mathrm{L}$ & $\mathrm{AICc}$ & $\triangle \mathrm{AICC}$ & $W_{\mathrm{i}}$ & $\begin{array}{c}\text { Evidence } \\
\text { ratio }\end{array}$ & $\begin{array}{c}\text { Cumulative } \\
\text { weight }\end{array}$ \\
\hline THg Prey Fish + Species + Length + Lake Elevation + Lake Area + Species $\times$ Length & 14 & 248.52 & 278.48 & 0.00 & 0.14 & 1.00 & 0.14 \\
\hline THg Prey Fish + Species + Length + Lake Elevation + Species $\times$ Length & 13 & 251.15 & 278.84 & 0.36 & 0.12 & 1.20 & 0.26 \\
\hline THg Prey Fish + Species + Length + Lake Elevation + Lake Perimeter + Lake Area + Species $\times$ Length & 15 & 247.24 & 279.49 & 1.01 & 0.09 & 1.66 & 0.35 \\
\hline THg Prey Fish + Species + Length + Lake Elevation + Lake Area + Lake Shape + Species $\times$ Length & 15 & 247.44 & 279.68 & 1.21 & 0.08 & 1.83 & 0.42 \\
\hline THg Prey Fish + Species + Length + Lake Elevation + Lake Shape + Species $\times$ Length & 14 & 250.37 & 280.33 & 1.85 & 0.06 & 2.52 & 0.48 \\
\hline $\mathrm{THg}$ Prey Fish + Species + Length + Date + Lake Elevation + Lake Area + Species $\times$ Length & 15 & 248.13 & 280.37 & 1.90 & 0.06 & 2.58 & 0.54 \\
\hline THg Prey Fish + Species + Length + Lake Elevation + Lake Perimeter + Lake Shape + Species $\times$ Length & 15 & 248.54 & 280.79 & 2.31 & 0.04 & 3.17 & 0.58 \\
\hline THg Prey Fish + Length + Lake Elevation + Lake Area & 6 & 271.80 & 284.18 & 5.70 & 0.01 & 17.28 & 0.88 \\
\hline THg Prey Fish + Species + Length + Lake Elevation + Lake Area & 10 & 265.08 & 286.09 & 7.61 & 0.00 & 44.93 & 0.94 \\
\hline THg Prey Fish + Species + Length + Lake Area + Species $\times$ Length & 13 & 258.58 & 286.27 & 7.79 & 0.00 & 49.13 & 0.95 \\
\hline Species + Length + Lake Elevation + Lake Area + Species $\times$ Length & 13 & 274.89 & 302.58 & 24.10 & 0.00 & $1.71 \times 10^{5}$ & 1.00 \\
\hline THg Prey Fish + Species + Lake Elevation + Lake Area & 9 & 391.46 & 410.28 & 131.80 & 0.00 & $4.18 \times 10^{28}$ & 1.00 \\
\hline Null (Lake as random effect) & 2 & 455.61 & 459.67 & 181.19 & 0.00 & $2.21 \times 10^{39}$ & 1.00 \\
\hline
\end{tabular}


Table 11. Appropriate range of data for each variable used in the predictive tool for use by natural resource managers.

[Means, minima, and maxima correspond to the distribution of data used to generate the predictive model, and the tool may have limited validity outside of these general data ranges. ha, hectare, $\mathrm{km}$, kilometer, $\mathrm{m}$, meter, mm, millimeter]

\begin{tabular}{|c|c|c|c|}
\hline Variables & Mean & Minimum & Maximum \\
\hline \multicolumn{4}{|l|}{ Date sampled: Grebes } \\
\hline Days from January 1 & 181 & 120 & 279 \\
\hline Calendar date & June 30 & April 30 & October 6 \\
\hline \multicolumn{4}{|l|}{ Date sampled: Fish } \\
\hline Days from January 1 & 204 & 133 & 283 \\
\hline Calendar date & July 23 & May 13 & October 10 \\
\hline \multicolumn{4}{|l|}{ Lake variables } \\
\hline Area (ha) & $2,658.8$ & 173.3 & $16,005.8$ \\
\hline Perimeter $(\mathrm{km})$ & 61.5 & 16.1 & 255.3 \\
\hline Elevation (m) & 691.5 & 42.4 & $2,062.0$ \\
\hline Shape index & 3.429 & 1.502 & 7.345 \\
\hline \multicolumn{4}{|l|}{ Sport fish } \\
\hline Total length (mm) & 397 & 178 & 726 \\
\hline \multicolumn{4}{|l|}{ Prey fish } \\
\hline Standard length (mm) & 58 & 18 & 123 \\
\hline
\end{tabular}

Table 12. Toxicity benchmarks and associated citations used in the predictive tool for natural resource managers.

[Values represent total mercury concentrations in micrograms per gram wet weight $[\mu \mathrm{g} / \mathrm{g} \mathrm{ww}$ ] for bird blood, $\mu \mathrm{g} / \mathrm{g}$ fresh wet weight for bird eggs, and $\mu \mathrm{g} / \mathrm{g}$ ww for sport fish]

\begin{tabular}{llllll}
\hline \multicolumn{1}{c}{ Tissue } & Low risk & Medium risk & High risk & $\begin{array}{c}\text { Extra high } \\
\text { risk }\end{array}$ & \multicolumn{1}{c}{ Citations } \\
\hline Bird blood & $<1.0$ & $1.0-2.0$ & $2.0-3.0$ & $>4.0$ & $\begin{array}{l}\text { Evers and others, 2004 } \\
\text { Bird eggs }\end{array}$ \\
$\begin{array}{llllll}\text { Sport fish-risk } \\
\text { to fish }\end{array}$ & $<0.25$ & $0.25-0.50$ & $0.50-0.65$ & $>0.65$ & $\begin{array}{l}\text { Heinz and others, 2009; Ackerman and } \\
\text { others, 2014 } \\
\text { Beckvar and others, 2005; Sandheinrich } \\
\text { and others, 2011 }\end{array}$ \\
\hline
\end{tabular}


Publishing support provided by the U.S. Geological Survey

Science Publishing Network, Tacoma Publishing Service Center

For more information concerning the research in this report, contact the Director, Western Ecological Research Center

U.S. Geological Survey

3020 State University Drive East

Sacramento, California 95819

http://werc.usgs.gov/ 

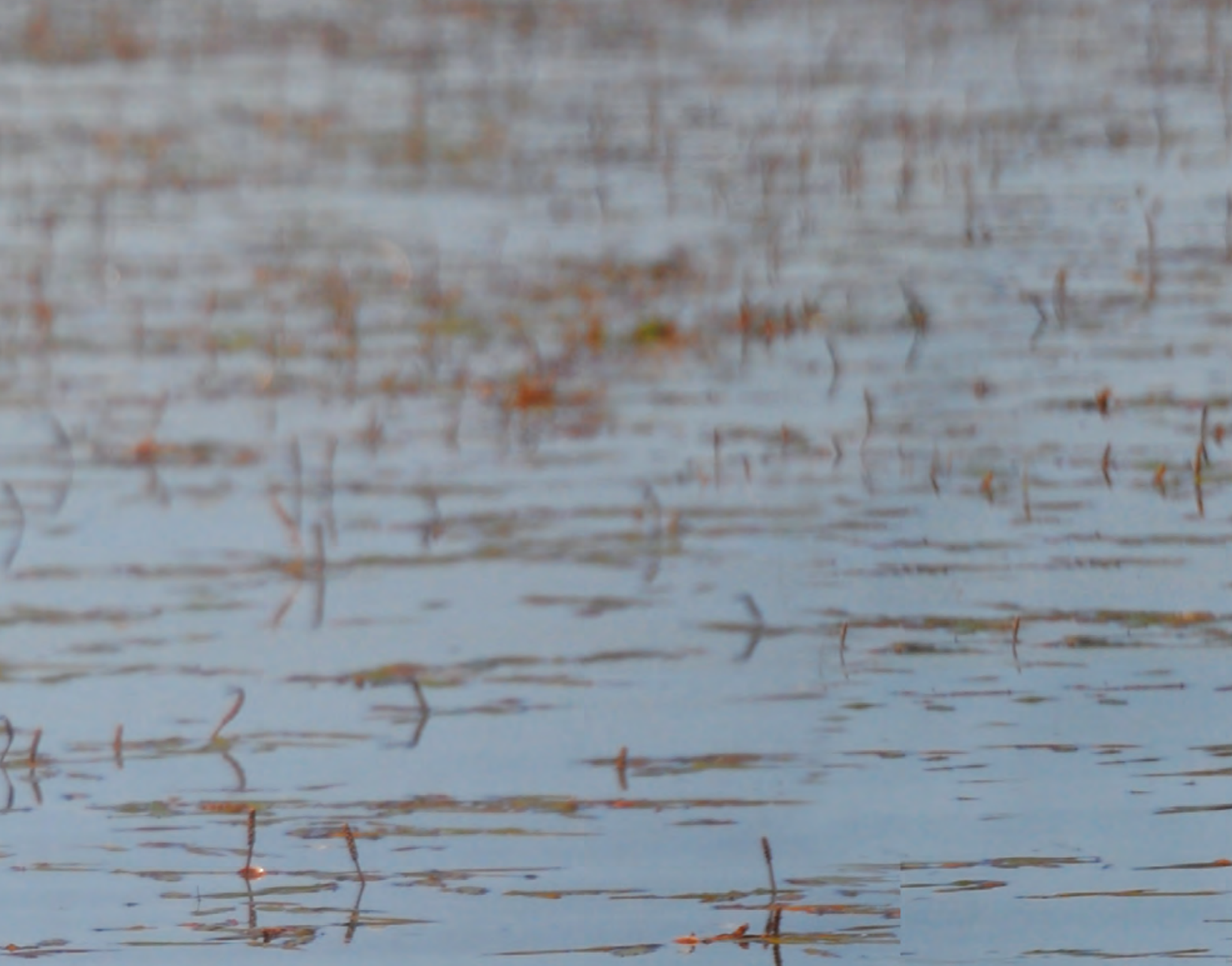

$+.+40$

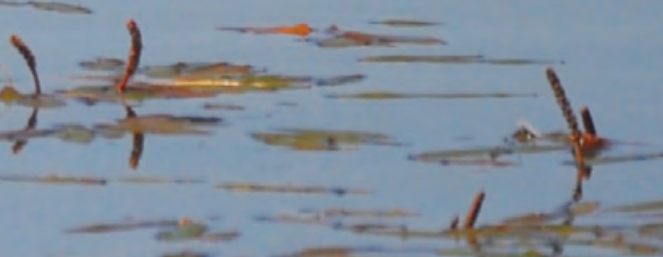

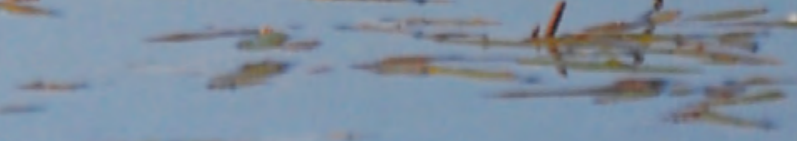

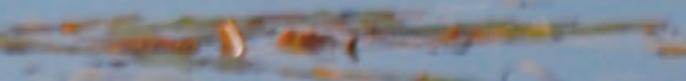

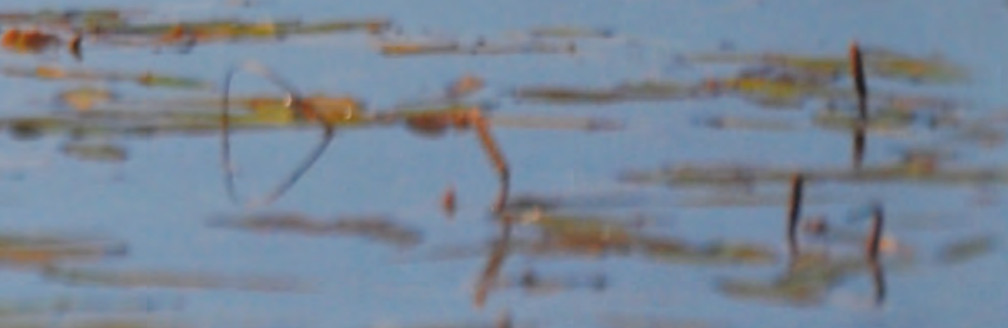

$=-4+2=$ $=$
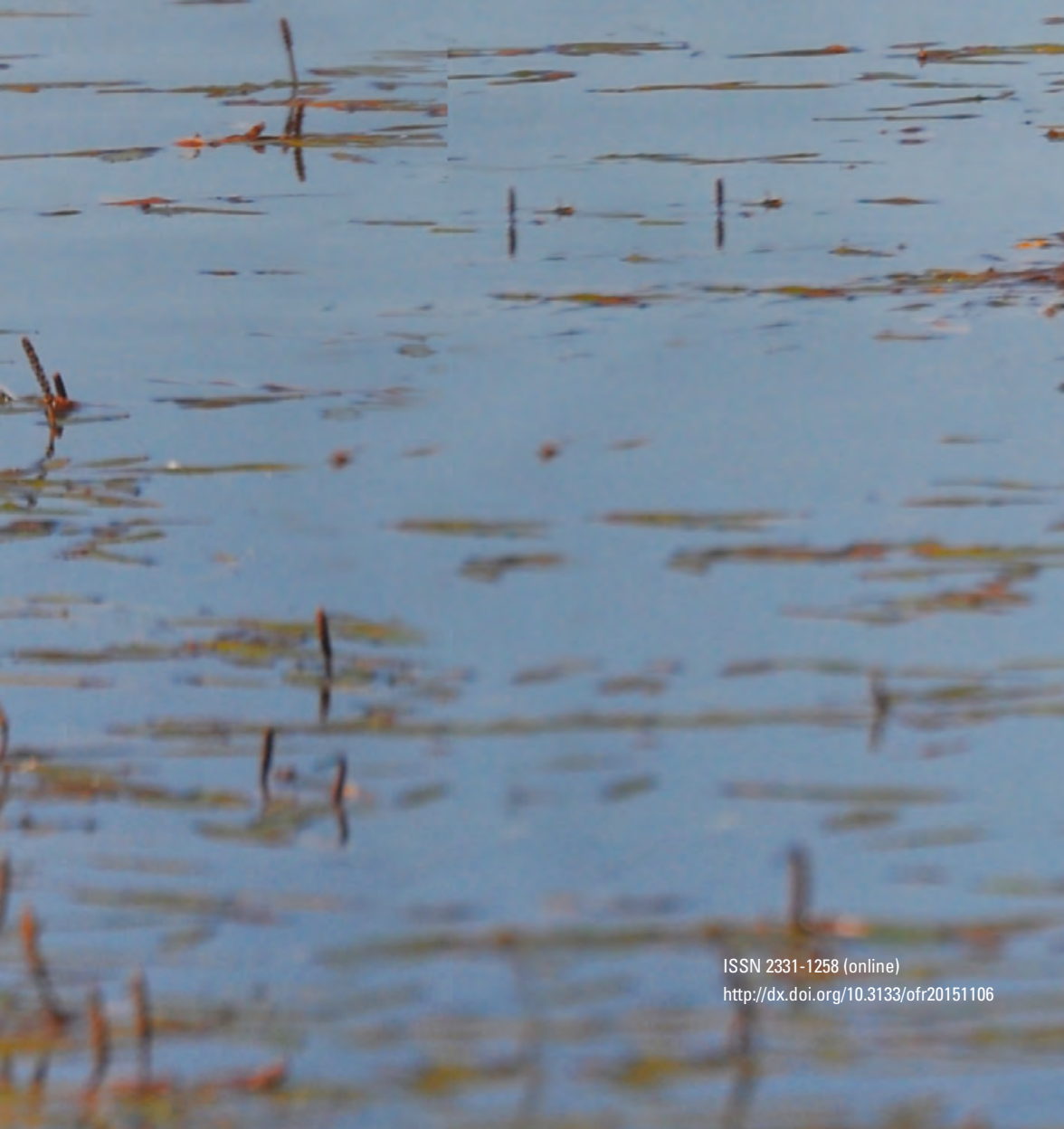